OAK RIDGE

NATIONAL LABORATORY

MANAGED BY UT-BATTELLE

FOR THE DEPARTMENT OF ENERGY

\title{
Air Dispersion Modeling for Building 3026C/D Demolition
}

\section{October 2009}

Prepared by

Richard C. Ward

Andrea L. Sjoreen

Keith F. Eckerman

\author{
Oak Ridge National Laboratory \\ One Bethel Valley Rd. \\ P.O. Box 2008 \\ Oak Ridge, Tennessee 37831-6085
}

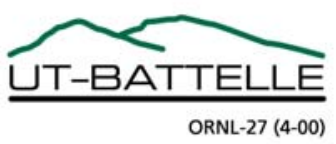




\section{DOCUMENT AVAILABILITY}

Reports produced after January 1, 1996, are generally available free via the U.S. Department of Energy (DOE) Information Bridge.

Web site http://www.osti.gov/bridge

Reports produced before January 1, 1996, may be purchased by members of the public from the following source.

National Technical Information Service

5285 Port Royal Road

Springfield, VA 22161

Telephone 703-605-6000 (1-800-553-6847)

TDD 703-487-4639

Fax 703-605-6900

E-mail info@ntis.gov

Web site http://www.ntis.gov/support/ordernowabout.htm

Reports are available to DOE employees, DOE contractors, Energy Technology Data

Exchange (ETDE) representatives, and International Nuclear Information System (INIS)

representatives from the following source.

Office of Scientific and Technical Information

P.O. Box 62

Oak Ridge, TN 37831

Telephone 865-576-8401

Fax 865-576-5728

E-mail reports@osti.gov

Web site http://www.osti.gov/contact.html

This report was prepared as an account of work sponsored by an agency of the United States Government. Neither the United States Government nor any agency thereof, nor any of their employees, makes any warranty, express or implied, or assumes any legal liability or responsibility for the accuracy, completeness, or usefulness of any information, apparatus, product, or process disclosed, or represents that its use would not infringe privately owned rights. Reference herein to any specific commercial product, process, or service by trade name, trademark, manufacturer, or otherwise, does not necessarily constitute or imply its endorsement, recommendation, or favoring by the United States Government or any agency thereof. The views and opinions of authors expressed herein do not necessarily state or reflect those of the United States Government or any agency thereof. 


\title{
Air Dispersion Modeling for Building 3026C/D Demolition
}

\author{
Richard C. Ward and Andrea L. Sjoreen \\ Modeling and Simulation Group \\ Computational Sciences and Engineering Division \\ Keith F. Eckerman \\ Dosimetry Research Team \\ Environmental Sciences Division
}

October 2009

Research sponsored the Integrated Facilities Deposition Project at Oak Ridge National Laboratory, UT-Battelle, LLC

Prepared by

OAK RIDGE NATIONAL LABORATORY

Oak Ridge, Tennessee 37831-6006

managed by

UT-BATTELLE, LLC

for the

U.S. DEPARTMENT OF ENERGY

under contract DE-AC05-00OR22725 



\section{CONTENTS}

LIST OF FIGURE

Page LIST OF TABLES

ABSTRACT.. vii

1. INTRODUCTION ix

2. METHEDOLOGY. .1

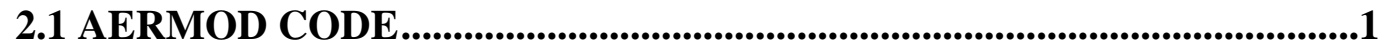

2.2 PLUME TRANSPORT FORMULATION....................................................2

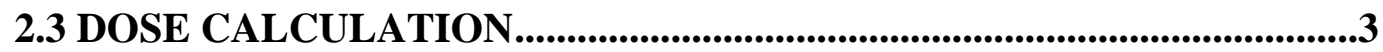

3. DATA USED............................................................................................................

3.1 LAND COVER CHARACTERISTICS............................................................

3.2 METEOROLOGY .............................................................................................4

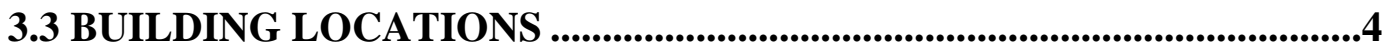

3.4 TOPOGRAPHY ..................................................................................................5

3.5 SOURCE CHARACTERISTICS ........................................................................5

3.6 RECEPTOR LOCATIONS ..........................................................................6

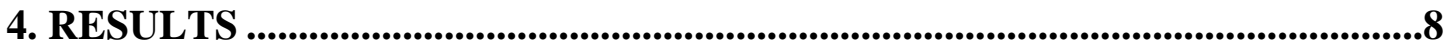

4.1 RESULTS FOR 2006 METEROLOGY …........................................12

4.2 RESULTS FOR 2007 METEROLOGY ...................................................22

4.3 RESULTS FOR 2008 METEROLOGY ……................................................32

5. CONCLUSIONS .................................................................................................42

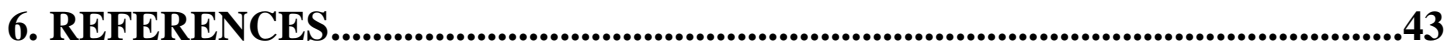

APPENDIX A. DETAILS OF THE AERMOD PROCEDURE ...............................45

APPENDIX B. WIND ROSES FOR 2006-2008 .......................................................49

APPENDIX C. BPIPPRIME INPUT / BUILDING DATA …..................................55

APPENDIX D. AERMAP INPUT FOR COMPUTING ELEVATION OF RECEPTOR LOCATIONS ...........................................................................63

APPENDIX E. SOURCE INVENTORIES AND EFFECTIVE DOSE COEFFICIENTS 



\section{LIST OF FIGURES}

Figure

Page

1. Source locations are shown as stars on a map of ORNL ..............................6

2. Source and receptor locations for S5 at ground level in the center of filter house 3140

3. Effective dose (Sv) for the limiting $1 \mathrm{~h}$ dispersion for S1 and 2006 meteorology

4. Effective dose (Sv) for the limiting $1 \mathrm{~h}$ dispersion for S2 and 2006 meteorology

5. Effective dose (Sv) for the limiting $1 \mathrm{~h}$ dispersion for S3 and 2006 meteorology

6. Effective dose (Sv) for the limiting $1 \mathrm{~h}$ dispersion for S4 and 2006 meteorology

7. Effective dose (Sv) for the limiting $1 \mathrm{~h}$ dispersion for S5 and 2006 meteorology

8. Effective dose (Sv) for the limiting $1 \mathrm{~h}$ dispersion for S1 and 2007 meteorology

9. Effective dose (Sv) for the limiting $1 \mathrm{~h}$ dispersion for S2 and 2007 meteorology

10. Effective dose (Sv) for the limiting $1 \mathrm{~h}$ dispersion for S3 and 2007 meteorology

11. Effective dose (Sv) for the limiting $1 \mathrm{~h}$ dispersion for S4 and 2007 meteorology

12. Effective dose (Sv) for the limiting $1 \mathrm{~h}$ dispersion for S5 and 2007 meteorology

13. Effective dose (Sv) for the limiting $1 \mathrm{~h}$ dispersion for $\mathrm{S} 1$ and 2008 meteorology

14. Effective dose (Sv) for the limiting $1 \mathrm{~h}$ dispersion for S2 and 2008 meteorology

15. Effective dose (Sv) for the limiting $1 \mathrm{~h}$ dispersion for $\mathrm{S} 3$ and 2008 meteorology

16. Effective dose (Sv) for the limiting $1 \mathrm{~h}$ dispersion for $\mathrm{S} 4$ and 2008 meteorology

17. Effective dose (Sv) for the limiting $1 \mathrm{~h}$ dispersion for S5 and 2008 meteorology

A1. Diagram of the AERMOD computational process ....................................46

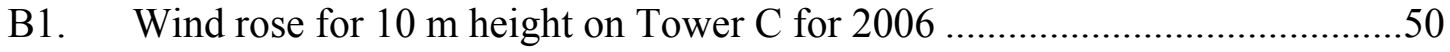

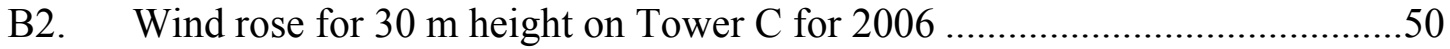

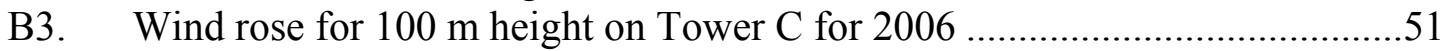

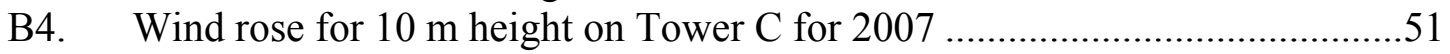

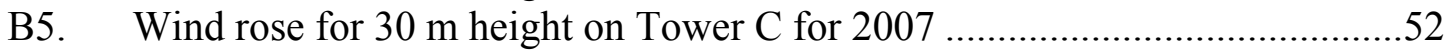

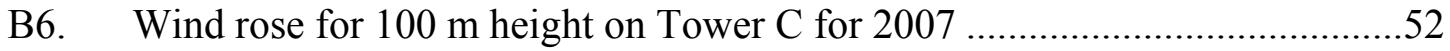

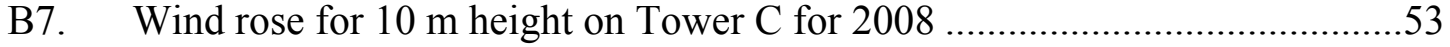




\section{LIST OF FIGURES (Cont.)}

Figure

Page

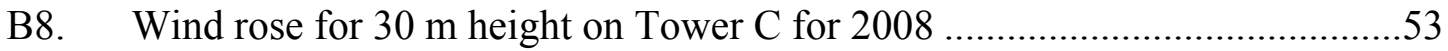

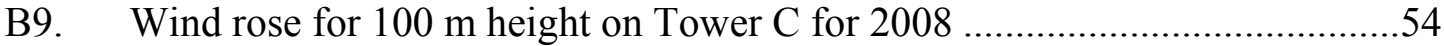




\section{LIST OF TABLES}

Table

Page

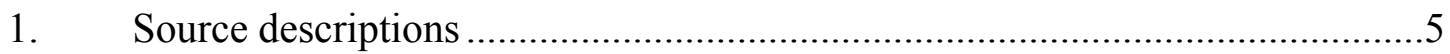

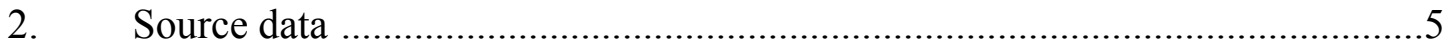

3. Source locations and heights ....................................................................

4. Maximum annual, highest $1 \mathrm{~h}$, and highest $3 \mathrm{~h}$ average dispersion coefficient $\left(\mathrm{s} / \mathrm{m}^{3}\right)$ and associated effective dose $(\mathrm{Sv})$ for building $3026 \mathrm{D} \ldots \ldots . . .8$

5. Maximum annual, highest $1 \mathrm{~h}$ and highest $3 \mathrm{~h}$ average dispersion coefficient $\left(\mathrm{s} / \mathrm{m}^{3}\right)$ and associated doses ( $\mathrm{Sv}$ ) for buildings $3026 \mathrm{C}$ and $3140 \ldots . .9$

6. Summary of dispersion coefficient and effective dose used to scale plots......10

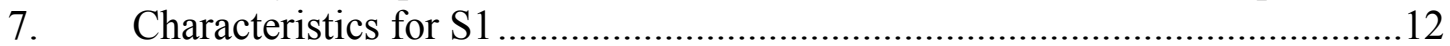

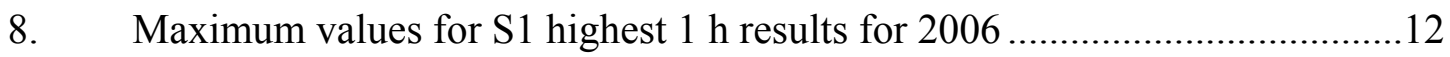

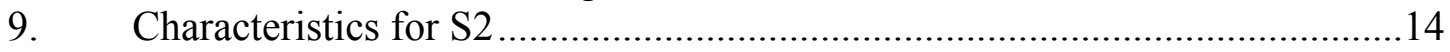

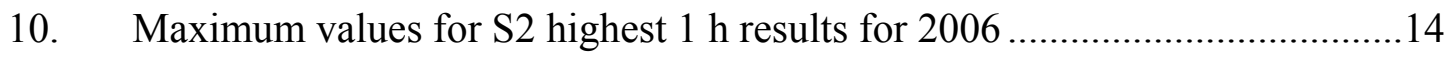

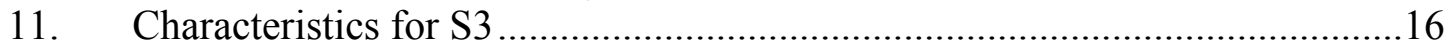

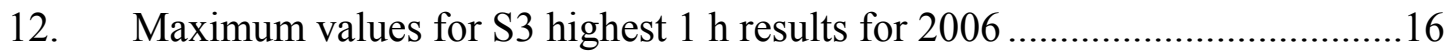

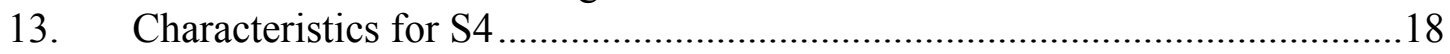

14. Maximum values for S4 highest $1 \mathrm{~h}$ results for $2006 \ldots \ldots \ldots \ldots \ldots \ldots \ldots \ldots \ldots \ldots \ldots \ldots \ldots . . . . .18$

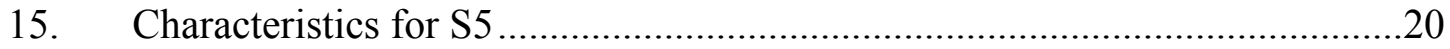

16. Maximum values for S5 highest $1 \mathrm{~h}$ results for $2006 \ldots \ldots \ldots \ldots \ldots \ldots \ldots \ldots \ldots \ldots \ldots \ldots \ldots . . . .20$

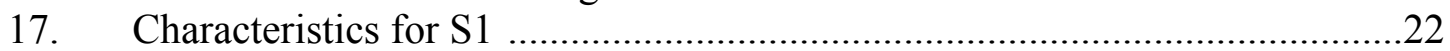

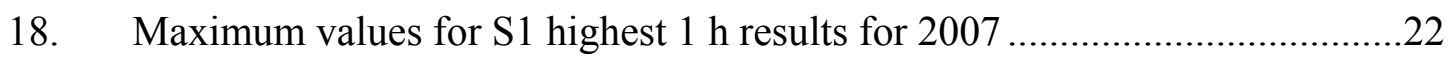

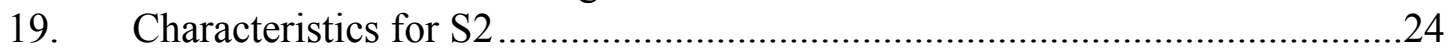

20. Maximum values for S2 highest $1 \mathrm{~h}$ results for $2007 \ldots \ldots \ldots \ldots \ldots \ldots \ldots \ldots \ldots \ldots \ldots \ldots \ldots . . . . .24$

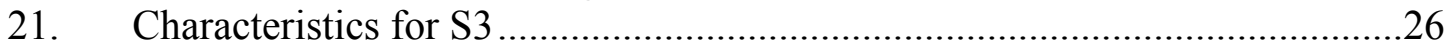

22. Maximum values for S3 highest $1 \mathrm{~h}$ results for $2007 \ldots \ldots \ldots \ldots \ldots \ldots \ldots \ldots \ldots \ldots \ldots \ldots \ldots . . .26$

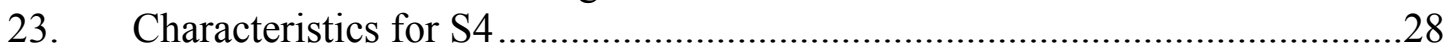

24. Maximum values for $\mathrm{S} 4$ highest $1 \mathrm{~h}$ results for $2007 \ldots \ldots \ldots \ldots \ldots \ldots \ldots \ldots \ldots \ldots \ldots \ldots \ldots . . .28$

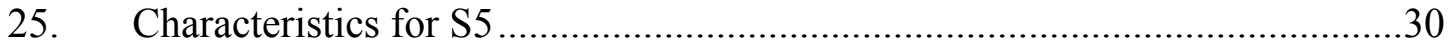

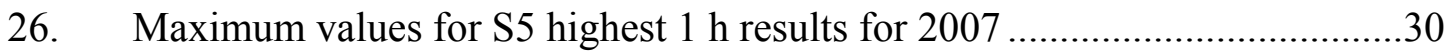

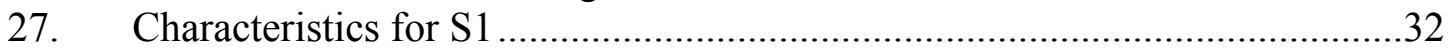

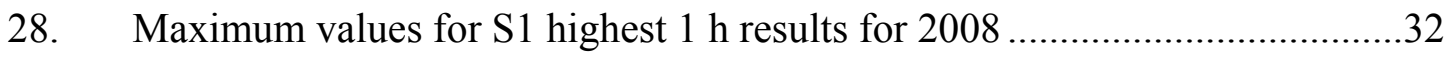

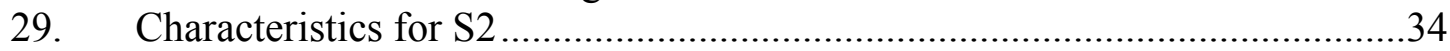

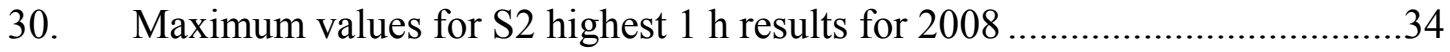

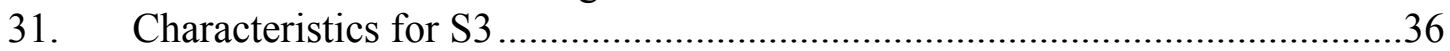

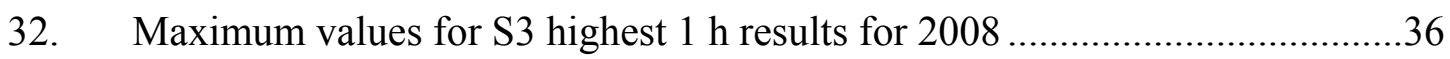

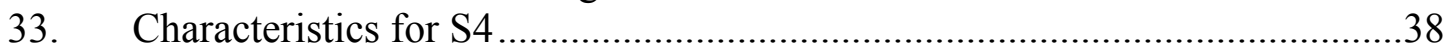

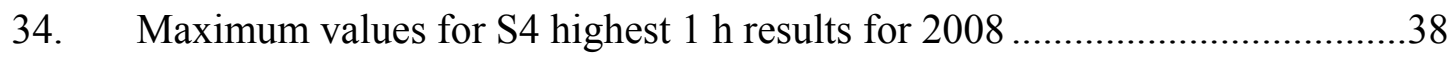

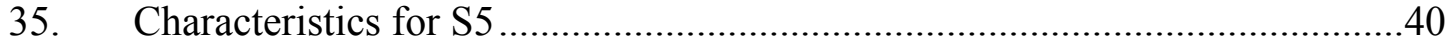




\section{LIST OF TABLES (Cont.)}

Table $\quad$ Page

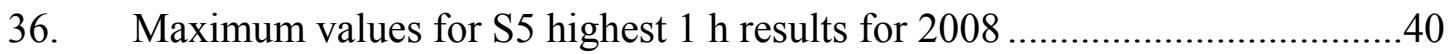

E.1. Dose coefficients for inhalation, submersion and ground plane exposures.....66

E.2 Radioactive material inventory summary for Bldg. 3026C ...........................67

E.3 Radioactive material inventory summary for Bldg. 3026D ..........................67

E.4 Radioactive material inventory summary for Filter House $3140 \ldots \ldots \ldots \ldots \ldots \ldots \ldots . . . .67$ 


\section{ABSTRACT}

This report presents estimates of dispersion coefficients and effective dose for potential air dispersion scenarios of uncontrolled releases from Oak Ridge National Laboratory (ORNL) buildings 3026C, 3026D, and 3140 prior to or during the demolition of the 3026

Complex. The Environmental Protection Agency (EPA) AERMOD system ${ }^{1-6}$ was used to compute these estimates. AERMOD stands for AERMIC Model, where AERMIC is the American Meteorological Society-EPA Regulatory Model Improvement Committee. Five source locations (three in building 3026D and one each in building 3026C and the filter house 3140) and associated source characteristics were determined with the customer. In addition, the area of study was determined and building footprints and intake locations of air-handling systems were obtained. In addition to the air intakes, receptor sites consisting of ground level locations on four polar grids $(50 \mathrm{~m}, 100 \mathrm{~m}, 200$ $\mathrm{m}$, and $500 \mathrm{~m}$ ) and two intersecting lines of points (50 m separation), corresponding to sidewalks along Central Avenue and Fifth Street. Three years of meteorological data (2006-2008) were used each consisting of three datasets: 1) National Weather Service data; 2) upper air data for the Knoxville-Oak Ridge area; and 3) local weather data from Tower C $(10 \mathrm{~m}, 30 \mathrm{~m}$ and $100 \mathrm{~m})$ on the ORNL reservation. Annual average air concentration, highest $1 \mathrm{~h}$ average and highest $3 \mathrm{~h}$ average air concentrations were computed using AERMOD for the five source locations for the three years of meteorological data. The highest $1 \mathrm{~h}$ average air concentrations were converted to dispersion coefficients to characterize the atmospheric dispersion as the customer was interested in the most significant response and the highest $1 \mathrm{~h}$ average data reflects the best time-averaged values available from the AERMOD code. Results are presented in tabular and graphical form. The results for dose were obtained using radionuclide activities for each of the buildings provided by the customer. ${ }^{7}$ Radiation dose was calculated assuming complete release of the building inventory as information was lacking regarding the portion of the building inventory expected to be released. Thus the results are derived using an extremely conservative release as documented in the Preliminary Hazard Screening report. ${ }^{7}$ To more closely approximate the result of a release, one must estimate the fraction of the total inventory released and multiply the results described above by that fraction. An example of how this calculation is accomplished is provided. Should an actual uncontrolled release occur, the results of this modeling effort could only be used to establish a rough order-of-magnitude for the event. 



\section{AIR DISPERSION MODELING FOR BUILIDING 3026C/D DEMOLITION}

October 12, 2009

\section{INTRODUCTION}

The AERMOD system ${ }^{1}$ was used to estimate the air concentrations resulting from a release of a pollutant from buildings 3026C, 3026D, and filter house 3140 , for potential air dispersion scenarios resulting from accidental release prior to or during the demolition of buildings $3026 \mathrm{C} / \mathrm{D}$. AERMOD ${ }^{2}$ is a complex terrain / wind-field model and is the model that EPA currently recommends for atmospheric pollutant modeling. AERMOD stands for AERMIC Model, where AERMIC is the American Meteorological Society/EPA Regulatory Model Improvement Committee. In this study, the scenarios were modeled using several different proposed heights and locations within the three buildings.

Three sets of receptors were considered: 1) locations at $50 \mathrm{~m}$ intervals following the sidewalk along Central Avenue (SW-NE direction) and roughly along Fifth Street (NWSE direction) perpendicular to Central Avenue; 2) a set of polar grids centered on the source location; and 3) air intakes on buildings on the ORNL campus outside an inner boundary which defines the buildings involved in the downwash calculation. The modeling included the effects of terrain, land cover type, and nearby buildings. Three years (2006-2008) of meteorological data were used including ORNL Tower C data and both ground level and upper air data from the KOQT site in Oak Ridge.

\section{METHODOLOGY}

\subsection{AERMOD CODE}

The AERMOD ${ }^{1}$ system consists of four additional preprocessors, AERMAP $^{3}$, AERMET $^{4}$, AERSURFACE $^{5}$, BPIPPRIME ${ }^{6}$, in addition to AERMOD ${ }^{2}$. AERSURFACE accepts the stack (source) location and local climate information as well as U.S. Geological Survey (USGS) land cover database to produce land cover characteristics for input to AERMET. AERMET preprocesses meteorological data. It requires National Weather Service data and upper air data. It also allows the use of on-site meteorology. AERMAP preprocesses terrain data and determines the elevation of the source and receptors. It accepts USGS digital elevation model (DEM) files as input. BPIPPRIME produces input for AERMOD that is used to estimate the effects of building wake. Input data for BPIPPRIME are the source location and elevation and the locations and ground elevations of nearby building corners and building heights.

AERMOD was run for a unit release, so that the resulting air concentrations could be applied to a variety of source amounts. Each proposed source location and height and 
each set of receptors were modeled separately. The building wake was computed for each source location and height. The same land cover, terrain, and meteorological data were used for each. Details of the procedure are outlined in Appendix A.

\subsection{PLUME TRANSPORT FORMULATION}

AERMOD (and its precursor, the ISC model) uses the steady-state Gaussian plume equation for a continuous elevated stack source. For each source and each hour, the origin of the source's coordinate system is placed at the ground surface at the base of the stack. The $\mathrm{x}$ axis is positive in the downwind direction, the $\mathrm{y}$ axis is crosswind (normal) to the $\mathrm{x}$ axis and the $\mathrm{z}$ axis extends vertically. The fixed receptor locations are converted to each source's coordinate system for each hourly concentration calculation.

The hourly concentrations calculated for each source at each receptor are summed to obtain the total concentration produced at each receptor by the combined source emissions. For a steady-state Gaussian plume, the hourly concentration $\chi$ at downwind distance $x(\mathrm{~m})$ and crosswind distance $y(\mathrm{~m})$ is given by:

$$
\chi(x, y)=\frac{V D Q}{2 u_{s} \sigma_{y} \sigma_{z}} \exp \left[-0.5\left(y / \sigma_{y}\right)^{2}\right],
$$

where:

$\chi \quad=$ the airborne concentration $\left(\mathrm{g} / \mathrm{m}^{3}\right)$ of the pollutant at location $\mathrm{x}, \mathrm{y}$,

$Q \quad=$ pollutant emission rate $(\mathrm{g} / \mathrm{s})$,

$V \quad=$ vertical term,

$D \quad=$ decay term, here taken to be 1.0 ,

$\sigma_{y}, \sigma_{z}=$ standard deviation of lateral and vertical concentration distribution (m), and

$u_{s} \quad=$ mean wind speed $(\mathrm{m} / \mathrm{s})$ at release height.

Equation (1) includes a vertical term $(V)$, a decay term $(D)$, and dispersion parameters $\left(\sigma_{y}\right.$ and $\sigma_{z}$ ). Both $\sigma_{y}$ and $\sigma_{z}$ are functions of the atmospheric stability class (i.e., a measure of the turbulence in the ambient atmosphere) and of the downwind distance to the receptor. The decay term $(D)$ accounts for radioactive decay of the pollutant during dispersal, which is taken to be 1.0 here, since the half-lives of the radionuclides are long relative to the travel time to the receptor location. The vertical term $(V)$ accounts for effects of source elevation, receptor elevation, plume rise, limited mixing in the vertical, and the gravitational settling and dry deposition of particulates (with diameters greater than about $0.1 \mu \mathrm{m}$ ). The quotient of airborne concentration and the release rate, $\chi / Q$, characterizes 
the dispersion conditions. If $Q$ has units of $\mathrm{g} / \mathrm{s}, u_{\mathrm{s}}$ of $\mathrm{m} / \mathrm{s}$ and both $\sigma_{y}$ and $\sigma_{y}$ have units of $\mathrm{m}$, then the dispersion coefficient, $\chi / Q$, has units of $\mathrm{s} / \mathrm{m}^{3}$.

\subsection{DOSE CALCULATION}

The radiation doses calculated here include contributions due to inhalation of the dispersing materials, exposure to penetrating radiations emitted by airborne dispersing materials (so-called submersion pathway), and exposure over a $4 \mathrm{~h}$ period to penetrating radiations emitted by materials deposited on the ground surface. However, it was shown (see Appendix E) that the dose is dominated by the inhalation pathway and thus only that component is addressed in the discussions below.

The effective dose $E(x, y)$ at location $x, y$, for a release of $Q(\mathrm{~Bq})$ is computed as:

$$
E(x, y)=K B R[\chi(x, y) / Q] Q e,
$$

where $\chi(x, y) / Q$ is the dispersion coefficient $\left(\mathrm{s} / \mathrm{m}^{3}\right)$ applicable at $x, y$ for the release point, $e$ is the effective dose coefficient $(\mathrm{Sv} / \mathrm{Bq})$ for inhalation of the dispersing material, $B R$ is the breathing rate of an adult $\left(1.5 \mathrm{~m}^{3} / \mathrm{h}\right)$, and $K$ is $1 / 3600 \mathrm{~h} / \mathrm{s}$. The effective dose coefficients for the radionuclides of interest here are given in Appendix E.

Equation (2) is applicable to each radionuclide in the release; the total dose being the sum of the contributions of each of the radionuclides. Since the radionuclides are all longlived and no nuclide-specific fractionation of the inventory is expected during the release, Eq. (2) can be rewritten as:

$$
E(x, y)=K B R[\chi(x, y) / Q] \sum_{i} Q_{i} e_{i}
$$

where $Q_{i}$ is the building inventory of nuclide $i$ and $e_{i}$ is nuclide's effective dose coefficient. Thus the doses are calculated assuming a complete release of the building inventory. To estimate the dose for a realistic release, one should multiply the doses shown in Tables 4 and 5 by a factor that represents that fraction of the building's inventory expected to be released.

\section{DATA USED}

\subsection{LAND COVER CHARACTERISTICS}

AERSURFACE requires the input of land cover data from the USGS National Land Cover Data 1992 archives, which is used to determine the land cover types for the userspecified location. The land cover generated is radial. For example, if AERSURFACE determines that most of the land to the north is forest, then the entire northern sector is treated as forest. It also requires the user to enter information on whether or not the site is in an arid region and whether the current year is abnormally wet or dry. Normal 
moisture and a non-arid region were used in this study. Up to 12 directional sectors may be used. Data may be computed on an annual, seasonal, or monthly basis. For this study, one sector and annual resolution were selected.

\subsection{METEOROLOGY}

AERMET requires hourly meteorological observations for one year from two sources: National Weather Service (NWS) ground surface observations and upper air soundings. It also accepts on-site data. The NWS data used was from the KOQT site in Oak Ridge, Tennessee. These data were obtained from the National Climatic Data Center. The upper air data used were the SODAR readings at the KOQT site. The on-site meteorological tower data used were from Tower $\mathrm{C}$, the tower closest to the releases. All three levels of measurements $(10 \mathrm{~m}, 30 \mathrm{~m}$, and $100 \mathrm{~m})$ were used. AERMET runs in three 'stages.' First, the data were checked for internal quality and consistency; second, the three output files were merged; and third, the AERMOD input files were created, incorporating data on the land cover characteristics. Because of the limitations on input formats, the NWS data had to be pre-processed and reformatted before they could be read by AERMET.

AERMOD was run separately for each of the three years of meteorology data (20062008). These three years represent a good spread on the meteorology because they were all relatively different. Years 2007 and 2008 were quite opposite one another, giving a high probability that the meteorology data covers the likely spreads in concentrations.

A separate dispersion calculation is made using each hour of weather data for a given year and three types of averages were computed: annual average, $1 \mathrm{~h}$ averages, and $3 \mathrm{~h}$ averages. The results varied across the three years with average annual concentrations being most similar to each other. Variations are more significant for $3 \mathrm{~h}$ and $1 \mathrm{~h}$ averages - the latter being the closest results to transient modeling obtainable with AERMOD. Average annual concentrations tend to follow the wind rose patterns. Wind roses for 2006-2008 for the three measurement heights of Tower C are shown in Figs. B1-B9 in Appendix B. Since we are primarily concerned with the significant events, we used the $1 \mathrm{~h}$ averages in this report.

\subsection{BUILDING LOCATIONS}

Twenty-nine existing buildings near the proposed releases were modeled using BPIPPRIME. They were buildings 3025E, 3025M, 3028, 3029, 3038, 3039, 3092, 3105, $3125,3150,3515,3525,3546,3550,3026 \mathrm{C}, 3026 \mathrm{D}, 3034,3036,3037,3047,3130$, $3137,3500,3508,3517,3542,3587,3606$, and 3618. The following buildings were modeled using two levels: 3026C, 3026D, 3500, 3508, and 3517. The required data are the location and ground elevation of the source, and for each building, the locations and ground elevations of the corners and the height of the building. The building data were provided by Damen Belcher. The BPIPPRIME input data files for each source are included in Appendix C. 


\subsection{TOPOGRAPHY}

AERMAP input are the UTM coordinates of the source and receptor locations along with USGS DEM files of topographic data for the area being modeled. AERMAP produces two files for input to AERMOD, one with the source location and ground elevation and the other with the receptors and their ground elevations. AERMAP was run separately for three receptor grids: a grid of locations along sidewalks, selected building air intake locations, and a set of concentric circular grids.

\subsection{SOURCE CHARACTERISTICS}

Five sources (potential locations of ambient release due to collapse of structure) were modeled, three in building 3026D, one in building 3026C, and one in building 3140. The five source locations are described in Table 1. In each case, the release was modeled as a stack release with diameter of $4 \mathrm{~m}$. We further assumed that the release was at ambient temperature with essentially zero release velocity. Thus, with the exception of release location, elevation and height, the source data all had the same set of physical characteristics as shown in Table 2. For each source the location (in UTM coordinates), elevation $(\mathrm{m})$ and height $(\mathrm{m})$ are shown in Table 3. Locations of sources are shown as stars in Fig. 1 below.

Table 1. Source descriptions

\begin{tabular}{|ll|}
\hline Source & Description \\
\hline Source 1 (S1) & Building 3026D - NW Corner at roof level \\
Source 2 (S2) & Building 3026D - Center line, left side near ground level \\
Source 3 (S3) & $\begin{array}{l}\text { Building 3026D - Center line, right side of at roof level of } \\
\text { maintenance covering }\end{array}$ \\
Source 4 (S4) & Building 3026C - NW side near ground level \\
Source 5 (S5) & Building 3140 - Center near ground level \\
\hline
\end{tabular}

Table 2. Source data

\begin{tabular}{|ll|}
\hline \multicolumn{1}{|c|}{ Datum } & \multicolumn{1}{c|}{ Value } \\
\hline Release rate & $1 \mathrm{~g} / \mathrm{s}$ \\
Temperature & $300 \mathrm{~K}$ \\
Exit velocity & $0.01 \mathrm{~m} / \mathrm{s}$ \\
Stack diameter & $4 \mathrm{~m}$ \\
\hline
\end{tabular}

Table 3. Source locations and heights

\begin{tabular}{|ccccc|}
\hline & \multicolumn{2}{c}{ Location (m) } & Elev & Height \\
& UTM & UTM & (m) & (m) \\
\hline Northing & Easting & & \\
S2 & 742095.5 & 3979226.0 & 243.75 & 14.63 \\
S3 & 742104.0 & 3979215.0 & 243.40 & 1 \\
S4 & 742111.0 & 3979221.0 & 243.41 & 12 \\
S5 & 742080.0 & 3979209.0 & 243.49 & 1 \\
\hline
\end{tabular}

Figure 1 shows a portion of area under study near buildings 3026C/D. S1 and S3 represent a failure of the roof at the location of greatest deterioration and above the two hot cells in 3026D. Results for S2 would depict a release from the floor of the Operating Area of the same building. S4 is the location of greatest roof deterioration in 3026C. 


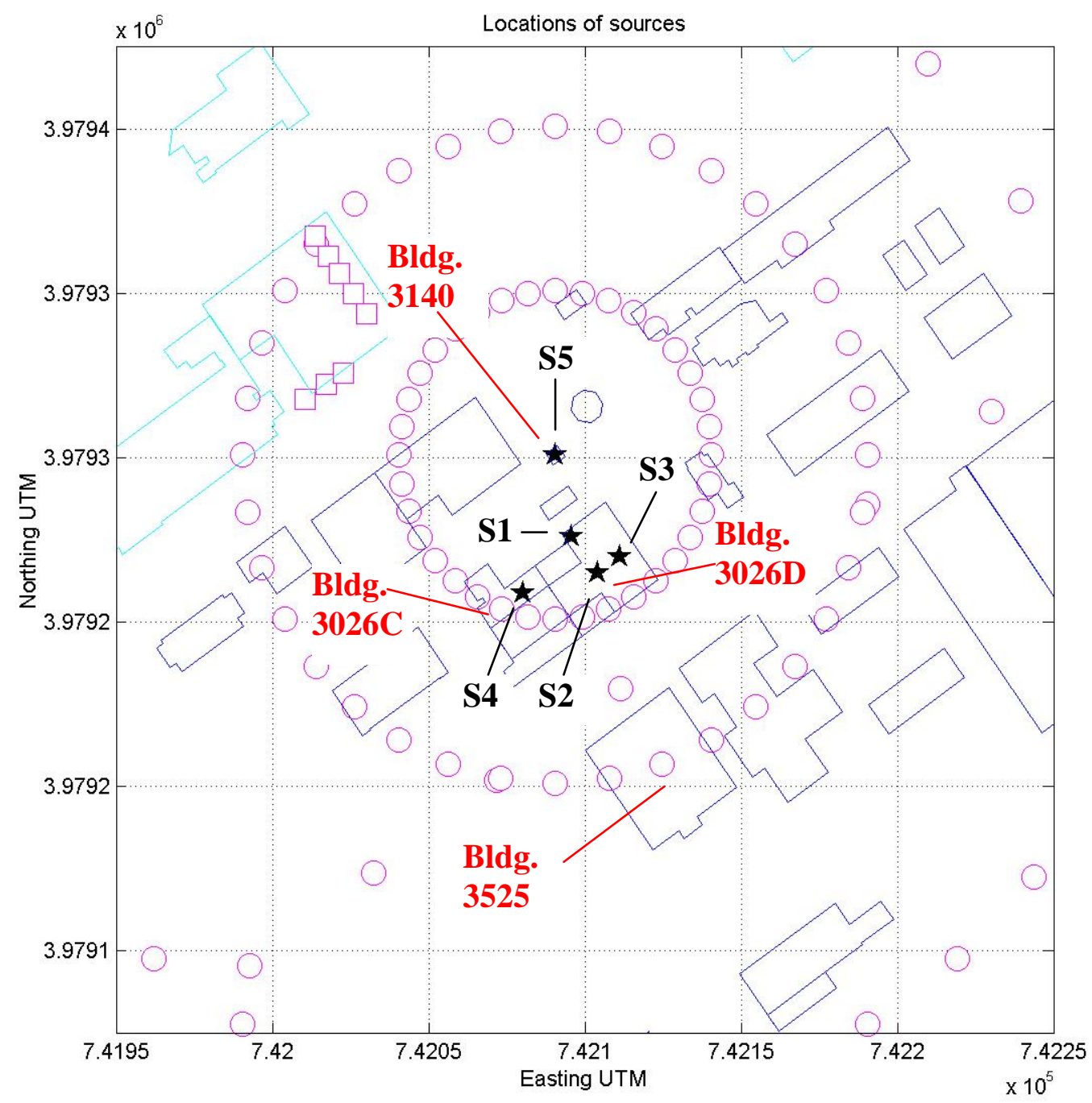

Fig. 1. Source locations are shown as stars on a map of ORNL. Polar grid receptor locations are relative to S5 (centered in filter house 3140). The other source locations are in building 3026D (S1-S3) and in building 3026C (S4).

\subsection{RECEPTOR LOCATIONS}

Three sets of receptors were used. The first consisted of points uniformly distributed (at $50 \mathrm{~m}$ intervals) along a sidewalk on the south side of Central Avenue (running SW-NE) and at $50 \mathrm{~m}$ intervals on a sidewalk roughly along Fifth Street (NW-SE). The second set of receptors consisted of concentric rings of polar grids of 50,100, 200 and $500 \mathrm{~m}$ radius with the origin at the source UTM coordinates. The third set of receptors were taken at approximate locations of air intakes on most buildings on the ORNL campus within the area of study, but outside the region considered for the downwash calculations. The receptor grids for S5 are shown in Fig. 2 along with the location of the source. The polar grids used 36 directions, starting at $10^{\circ}$ and incrementing by $10^{\circ}$ clockwise. The interval between points on the sidewalk grids was $50 \mathrm{~m}$. The air intake locations are marked with square symbols. 
The sidewalk receptors were chosen to provide concentrations for typical heavilytrafficked pathways near the source locations and further away. The air intake receptor locations and elevations give an indication of concentrations entering buildings. The polar grid provides general broader coverage of concentration results at ground level over the entire region.

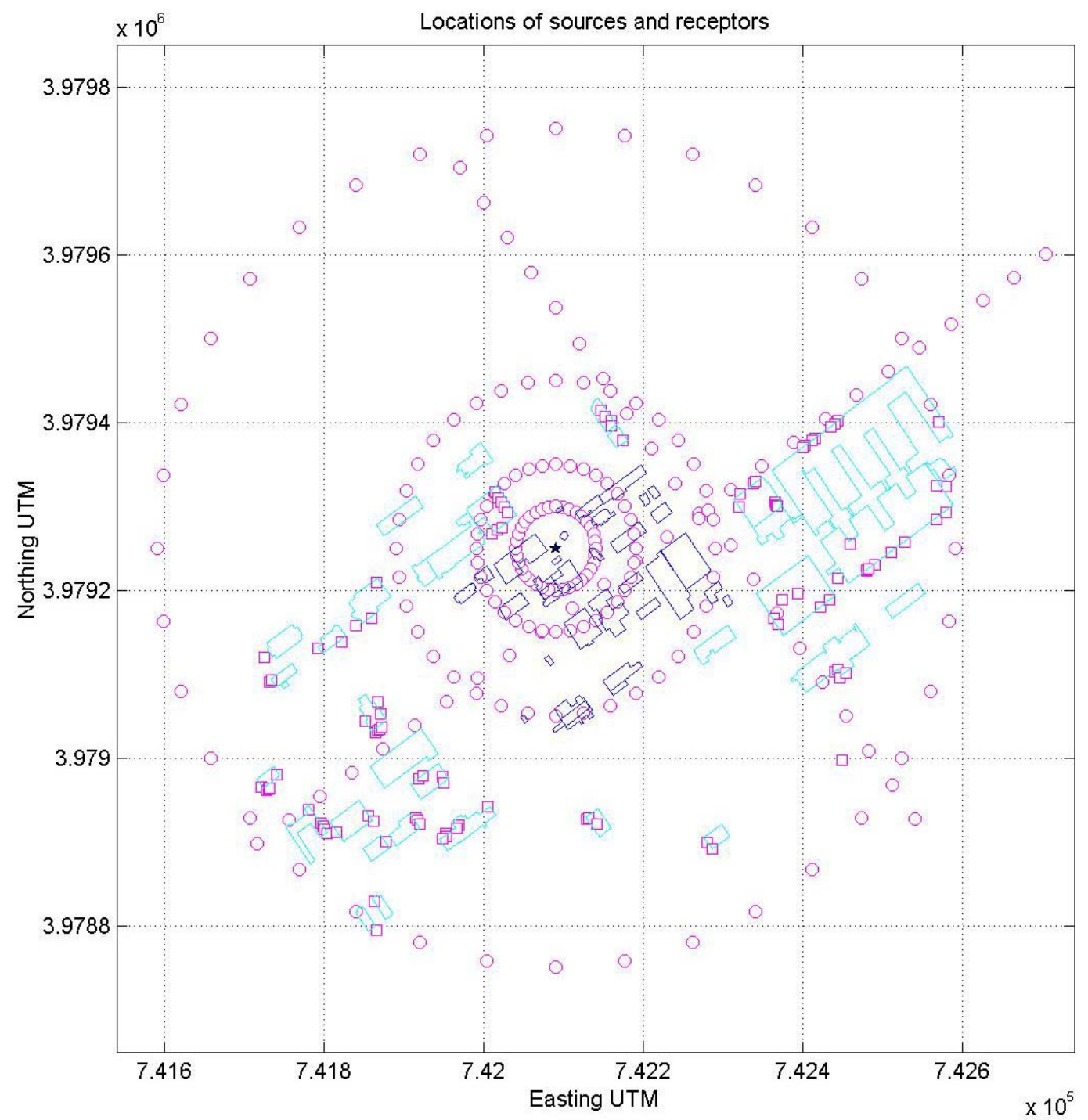

Fig. 2. Source and receptor locations for S5 at ground level in the center of filter house 3140. The polar grid and sidewalk receptor locations are shown as circles and the air intake receptor locations are shown as squares.

The AERMAP code must be run using the receptor UTM coordinates to obtain the elevations of the receptor location. An example of this is shown in Appendix D for the polar grid receptor locations for S5. 


\section{RESULTS}

Separate computations were made using AERMOD for each of the five source locations and for the three sets of receptors (sidewalks, polar gird, and air intakes) for three years of meteorological data (2006-2008). Table 4 shows the maximum values for the annual average, highest $1 \mathrm{~h}$ average, and highest $3 \mathrm{~h}$ average dispersion coefficients $\left(\mathrm{s} / \mathrm{m}^{3}\right)$ and associated effective dose (Sv) for sources (S1-S3) located in building 3026D for the three years of MET data (2006-2008). Results are for polar grid, sidewalk and air intake receptor locations. The maximum value in any one year (shown in bold font) is used to scale the plots for each source location for all receptors. The radioactive material inventory for building 3026D is shown in Table E. 3 of Appendix E.

Table 4. Maximum annual, highest $1 \mathrm{~h}$, and highest $3 \mathrm{~h}$ average dispersion coefficient $\left(\mathrm{s} / \mathrm{m}^{3}\right)$ and associated effective dose (Sv) for building 3026D

Includes source locations S1-S3 for three years of MET data (2006-8)

\begin{tabular}{|c|c|c|c|c|c|c|c|}
\hline \multirow{2}{*}{$\begin{array}{c}3026 \mathrm{D} \\
\mathrm{S} 1\end{array}$} & \multicolumn{4}{|c|}{ Dispersion Coefficient $\left(\mathrm{s} / \mathrm{m}^{3}\right)$} & \multicolumn{3}{|c|}{ Effective Dose (Sv) } \\
\hline & & 2006 & 2007 & 2008 & 2006 & 2007 & 2008 \\
\hline Ann. Avg. & Polar & $2.64 \mathrm{E}-4$ & 3.06E-4 & $2.39 \mathrm{E}-4$ & $2.31 \mathrm{E}-2$ & 2.67E-2 & 2.09E-2 \\
\hline Ann. Avg. & Sidewalks & $1.86 \mathrm{E}-4$ & $1.55 \mathrm{E}-4$ & 1.59E-4 & $1.62 \mathrm{E}-2$ & 1.35E-2 & 1.39E-2 \\
\hline Ann. Avg. & Intakes & 8.01E-5 & $1.25 \mathrm{E}-4$ & $1.15 \mathrm{E}-4$ & $6.99 \mathrm{E}-3$ & 1.10E-2 & $1.00 \mathrm{E}-2$ \\
\hline High $1 \mathrm{~h}$ & Polar & $5.37 \mathrm{E}-3$ & 7.16E-3 & $6.74 \mathrm{E}-3$ & 4.69E-1 & 6.25E-1 & $5.88 \mathrm{E}-1$ \\
\hline High $1 \mathrm{~h}$ & Sidewalks & $5.24 \mathrm{E}-3$ & $5.08 \mathrm{E}-3$ & $6.59 \mathrm{E}-3$ & 4.57E-1 & 4.43E-1 & $5.75 \mathrm{E}-1$ \\
\hline High $1 \mathrm{~h}$ & Intakes & $1.22 \mathrm{E}-3$ & 3.03E-3 & $1.62 \mathrm{E}-3$ & 1.07E-1 & 2.65E-1 & $1.42 \mathrm{E}-1$ \\
\hline High $3 \mathrm{~h}$ & Polar & $4.16 \mathrm{E}-3$ & $4.00 \mathrm{E}-3$ & $4.32 E-3$ & $3.63 \mathrm{E}-1$ & 1.17E-1 & $3.77 \mathrm{E}-1$ \\
\hline High $3 \mathrm{~h}$ & Sidewalks & $3.98 \mathrm{E}-3$ & $3.04 \mathrm{E}-3$ & 4.19E-3 & 3.47E-1 & 2.66E-1 & 3.65E-1 \\
\hline High $3 \mathrm{~h}$ & Intakes & $9.00 \mathrm{E}-4$ & 1.19E-3 & $8.88 \mathrm{E}-4$ & $7.85 \mathrm{E}-2$ & $1.04 \mathrm{E}-1$ & $7.75 \mathrm{E}-2$ \\
\hline $\mathrm{S} 2$ & & 2006 & 2007 & 2008 & 2006 & 2007 & 2008 \\
\hline Ann. Avg. & Polar & $1.05 \mathrm{E}-3$ & $1.10 \mathrm{E}-3$ & $7.24 \mathrm{E}-4$ & $9.14 \mathrm{E}-2$ & 9.57E-2 & $6.32 \mathrm{E}-2$ \\
\hline Ann. Avg. & Sidewalks & $1.04 \mathrm{E}-3$ & $1.06 \mathrm{E}-3$ & $6.53 \mathrm{E}-4$ & $9.08 \mathrm{E}-2$ & $9.29 \mathrm{E}-2$ & 5.70E-2 \\
\hline Ann. Avg. & Intakes & $1.55 \mathrm{E}-4$ & 1.70E-4 & 1.63E-4 & $1.35 \mathrm{E}-2$ & $1.49 \mathrm{E}-2$ & 1.42E-2 \\
\hline High $1 \mathrm{~h}$ & Polar & $4.89 \mathrm{E}-2$ & 4.78E-2 & 8.74E-2 & 4.27 & 4.17 & 7.63 \\
\hline High $1 \mathrm{~h}$ & Sidewalks & $7.60 \mathrm{E}-2$ & 7.10E-2 & 8.13E-2 & 6.63 & 6.19 & 7.09 \\
\hline High $1 \mathrm{~h}$ & Intakes & $5.83 \mathrm{E}-3$ & 7.66E-3 & 8.21E-3 & 5.09E-1 & 6.68E-1 & 7.16E-1 \\
\hline High $3 \mathrm{~h}$ & Polar & $2.28 \mathrm{E}-2$ & 2.52E-2 & 2.92E-2 & 1.99 & 2.20 & 2.55 \\
\hline High $3 \mathrm{~h}$ & Sidewalks & $2.53 \mathrm{E}-2$ & 3.30E-2 & 3.34E-2 & 2.21 & 2.88 & 2.92 \\
\hline High $3 \mathrm{~h}$ & Intakes & $2.99 \mathrm{E}-3$ & $2.99 \mathrm{E}-3$ & $3.74 \mathrm{E}-3$ & 2.61E-1 & 2.60E-1 & $3.26 \mathrm{E}-1$ \\
\hline S3 & & 2006 & 2007 & 2008 & 2006 & 2007 & 2008 \\
\hline Ann. Avg. & Polar & $7.08 \mathrm{E}-4$ & 8.88E-4 & $6.75 E-4$ & 6.17E-2 & 7.75E-2 & $5.89 \mathrm{E}-2$ \\
\hline Ann. Avg. & Sidewalks & $3.64 \mathrm{E}-4$ & 4.14E-4 & $3.04 \mathrm{E}-4$ & $3.18 \mathrm{E}-2$ & 3.61E-2 & 2.66E-2 \\
\hline Ann. Avg. & Intakes & $9.16 \mathrm{E}-5$ & $1.22 \mathrm{E}-4$ & 1.16E-4 & $7.99 \mathrm{E}-3$ & $1.07 \mathrm{E}-2$ & 1.02E-2 \\
\hline High $1 \mathrm{~h}$ & Polar & $1.15 \mathrm{E}-2$ & $1.66 \mathrm{E}-2$ & 8.04E-3 & 1.00 & 1.45 & 7.01E-1 \\
\hline High $1 \mathrm{~h}$ & Sidewalks & $1.31 \mathrm{E}-2$ & $9.61 E-3$ & 2.13E-2 & 1.15 & 7.56E-1 & 1.86 \\
\hline High $1 \mathrm{~h}$ & Intakes & $1.72 \mathrm{E}-3$ & $2.22 \mathrm{E}-3$ & $1.90 \mathrm{E}-3$ & $1.50 \mathrm{E}-1$ & 1.94E-1 & 1.66E-1 \\
\hline High $3 \mathrm{~h}$ & Polar & $7.55 \mathrm{E}-3$ & $1.21 \mathrm{E}-2$ & $5.06 \mathrm{E}-3$ & $6.59 \mathrm{E}-1$ & 1.05 & 4.42E-1 \\
\hline High $3 \mathrm{~h}$ & Sidewalks & $4.38 \mathrm{E}-3$ & $6.34 \mathrm{E}-3$ & $7.12 \mathrm{E}-3$ & 3.83E-1 & $5.54 \mathrm{E}-1$ & $6.21 \mathrm{E}-1$ \\
\hline High $3 \mathrm{~h}$ & Intakes & 7.04E-4 & $8.14 \mathrm{E}-4$ & 1.10E-3 & $6.14 \mathrm{E}-2$ & 7.10E-2 & $9.60 \mathrm{E}-2$ \\
\hline
\end{tabular}


Table 5 below shows the maximum values for the annual average, highest $1 \mathrm{~h}$ average, and highest $3 \mathrm{~h}$ average dispersion coefficients $\left(\mathrm{s} / \mathrm{m}^{3}\right)$ and associated effective dose (Sv) for sources located in buildings 3026C (S4) and 3140 (S5) for the three years of meteorology data (2006-2008). Results are for polar grid, sidewalk and air intake receptor locations. The maximum value in any one year is used to scale the plots for each source location for all receptors. The radioactive material inventory for buildings 3026C and 3140 are shown as Table E.2 and Table E.4 respectively of Appendix E.

Table 5. Maximum annual, highest $1 \mathrm{~h}$ and highest $3 \mathrm{~h}$ average dispersion coefficient $\left(\mathrm{s} / \mathrm{m}^{3}\right)$ and associated doses (Sv) for buildings $3026 \mathrm{C}$ and 3140

Includes sources S4 (3026C) and S5 (3140) for three years of MET data (2006-8)

\begin{tabular}{|c|c|c|c|c|c|c|c|}
\hline $3026 C$ & \multicolumn{4}{|c|}{ Dispersion Coefficient $\left(\mathrm{s} / \mathrm{m}^{3}\right)$} & \multicolumn{3}{|c|}{ Effective Dose (Sv) } \\
\hline S4 & & 2006 & 2007 & 2008 & 2006 & 2007 & 2008 \\
\hline Ann. Avg. & Polar & 1.10E-3 & $1.16 \mathrm{E}-3$ & $9.10 \mathrm{E}-4$ & $1.50 \mathrm{E}-4$ & $1.58 \mathrm{E}-4$ & $1.24 \mathrm{E}-4$ \\
\hline Ann. Avg. & Sidewalks & 7.09E-4 & $7.50 \mathrm{E}-4$ & $6.29 \mathrm{E}-4$ & 9.67E-5 & $1.02 E-4$ & 8.57E-5 \\
\hline Ann. Avg. & Intakes & $1.28 \mathrm{E}-4$ & $1.44 \mathrm{E}-4$ & 1.43E-4 & 1.74E-5 & 1.97E-5 & 1.95E-5 \\
\hline High $1 \mathrm{~h}$ & Polar & 3.80E-2 & $3.67 \mathrm{E}-2$ & 4.71E-2 & $5.18 \mathrm{E}-3$ & $5.00 \mathrm{E}-3$ & $6.42 E-3$ \\
\hline High $1 \mathrm{~h}$ & Sidewalks & 1.67E-2 & $2.29 \mathrm{E}-2$ & $7.85 \mathrm{E}-2$ & $2.28 \mathrm{E}-3$ & $3.12 \mathrm{E}-3$ & $1.07 \mathrm{E}-2$ \\
\hline High $1 \mathrm{~h}$ & Intakes & $5.86 \mathrm{E}-3$ & $6.45 \mathrm{E}-3$ & $6.09 \mathrm{E}-3$ & 8.00E-4 & 8.79E-4 & 8.31E-4 \\
\hline High $3 \mathrm{~h}$ & Polar & $1.78 \mathrm{E}-2$ & 1.66E-2 & $1.64 \mathrm{E}-2$ & $2.43 \mathrm{E}-3$ & $2.26 \mathrm{E}-3$ & $2.23 \mathrm{E}-3$ \\
\hline High 3 h & Sidewalks & 1.06E-2 & $1.01 \mathrm{E}-2$ & $2.69 \mathrm{E}-2$ & $1.45 \mathrm{E}-3$ & $1.37 \mathrm{E}-3$ & $3.67 \mathrm{E}-3$ \\
\hline High $3 \mathrm{~h}$ & Intakes & 2.91E-3 & 2.31E-3 & 2.69E-3 & 3.97E-4 & $3.14 \mathrm{E}-4$ & 3.67E-4 \\
\hline 3140 & \multicolumn{4}{|c|}{ Dispersion Coefficient $\left(\mathrm{s} / \mathrm{m}^{3}\right)$} & \multicolumn{3}{|c|}{ Dose (Sv) } \\
\hline S5 & & 2006 & 2007 & 2008 & 2006 & 2007 & 2008 \\
\hline Ann. Avg. & Polar & $6.53 \mathrm{E}-4$ & 7.92E-4 & $7.16 \mathrm{E}-4$ & $7.68 \mathrm{E}-8$ & 9.32E-8 & $8.42 \mathrm{E}-8$ \\
\hline Ann. Avg. & Sidewalks & 4.31E-4 & 5.78E-4 & 5.02E-4 & 5.07E-8 & 6.80E-8 & 5.91E-8 \\
\hline Ann. Avg. & Intakes & $2.12 \mathrm{E}-4$ & 2.85E-4 & $2.56 \mathrm{E}-4$ & $2.50 \mathrm{E}-8$ & 3.35E-8 & 3.01E-8 \\
\hline High $1 \mathrm{~h}$ & Polar & 2.01E-2 & $2.24 \mathrm{E}-2$ & 5.92E-2 & $2.37 \mathrm{E}-6$ & 2.64E-6 & 6.97E-6 \\
\hline High $1 \mathrm{~h}$ & Sidewalks & 1.17E-2 & $1.91 \mathrm{E}-2$ & $1.79 \mathrm{E}-2$ & $1.38 \mathrm{E}-6$ & $2.25 \mathrm{E}-6$ & $2.11 \mathrm{E}-6$ \\
\hline High $1 \mathrm{~h}$ & Intakes & 4.95E-3 & $5.16 \mathrm{E}-3$ & 7.33E-3 & $5.82 \mathrm{E}-7$ & $6.08 \mathrm{E}-7$ & 8.62E-7 \\
\hline High $3 \mathrm{~h}$ & Polar & 7.93E-3 & $1.02 \mathrm{E}-2$ & 2.15E-2 & 9.33E-7 & $1.20 \mathrm{E}-6$ & 2.54E-6 \\
\hline High $3 \mathrm{~h}$ & Sidewalks & 7.17E-3 & $9.85 E-3$ & $1.08 \mathrm{E}-2$ & 8.43E-7 & 1.16E-6 & $1.66 \mathrm{E}-6$ \\
\hline High $3 \mathrm{~h}$ & Intakes & $3.19 E-3$ & $2.75 E-3$ & $2.51 E-3$ & $3.75 \mathrm{E}-7$ & 3.23E-7 & 2.95E-7 \\
\hline
\end{tabular}

An air concentration of $2.64 \mathrm{E}-4 \mathrm{~g} / \mathrm{m}^{3}$ (or $263 \mu \mathrm{g} / \mathrm{m}^{3}$ ) would be predicted at a location characterized by a diffusion coefficient of $2.64 \mathrm{E}-04 \mathrm{~s} / \mathrm{m}^{3}$ given a release rate of $1 \mathrm{~g} / \mathrm{s}$. Correspondingly a release of $1 \mathrm{~g}$ would yield an integrated air concentration of 2.64E-04 $\mathrm{g}-\mathrm{s} / \mathrm{m}^{3}$ at the location.

Plots of results for the effective dose (Sv) computed from the highest $1 \mathrm{~h}$ average dispersion coefficients $\left(\mathrm{s} / \mathrm{m}^{3}\right)$ for each of three meteorology data sets are shown on the following pages since they represent the best illustration of a real-world release scenario. Summaries are presented for each source followed by plots of the dose for the entire study area and for an enlarged area close to the source. The source is indicated by a star. 
To properly scale plots of dispersion coefficients and doses, we used the maximum value over all three years for each set of receptors (shown in bold font in Tables 4 and 5). Table 6 summarizes these scaling values for the plots of dispersion coefficients $\left(\mathrm{s} / \mathrm{m}^{3}\right)$ and effective dose (Sv) for five source locations and for the three years of MET data (2006-2008).

Table 6. Summary of dispersion coefficient and effective dose used to scale plots

\begin{tabular}{|c|c|c|c|}
\hline \multirow[b]{2}{*}{ SOURCE } & \multicolumn{3}{|c|}{ Scale Values for Plots } \\
\hline & & $\chi / Q\left(\mathrm{~s} / \mathrm{m}^{3}\right)$ & $\begin{array}{l}\text { Effective } \\
\text { Dose(Sv) }\end{array}$ \\
\hline \multirow{3}{*}{$\begin{array}{l}\text { S1: NW Corner of } \\
\text { 3026D at roof level }\end{array}$} & Ann. Avg. & $3.06 \mathrm{E}-4$ & 2.67E-02 \\
\hline & Highest $1 \mathrm{~h}$ & 7.16E-3 & $6.25 \mathrm{E}-01$ \\
\hline & Highest $3 \mathrm{~h}$ & $4.32 \mathrm{E}-3$ & 3.77E-01 \\
\hline \multirow{3}{*}{$\begin{array}{l}\text { S2: Center line, left } \\
\text { side of 3026D near } \\
\text { ground level }\end{array}$} & Ann. Avg. & $1.10 \mathrm{E}-3$ & 9.57E-02 \\
\hline & Highest $1 \mathrm{~h}$ & 8.74E-2 & 7.63 \\
\hline & Highest $3 \mathrm{~h}$ & 3.34E-2 & 2.92 \\
\hline \multirow{3}{*}{$\begin{array}{l}\text { S3: Center line, above } \\
\text { 3026D maintenance } \\
\text { roof }\end{array}$} & Ann. Avg. & 8.88E-4 & 7.75E-02 \\
\hline & Highest $1 \mathrm{~h}$ & 2.13E-2 & 1.86 \\
\hline & Highest $3 \mathrm{~h}$ & $1.21 \mathrm{E}-2$ & 1.05 \\
\hline \multirow{3}{*}{$\begin{array}{l}\text { S4: NW corner of } \\
\text { 3026C near ground } \\
\text { level }\end{array}$} & Ann. Avg. & 1.16E-3 & $1.58 E-04$ \\
\hline & Highest $1 \mathrm{~h}$ & $7.85 \mathrm{E}-2$ & 1.07E-02 \\
\hline & Highest $3 \mathrm{~h}$ & 2.69E-2 & 3.67E-03 \\
\hline \multirow{3}{*}{$\begin{array}{c}\text { S5: Center of } 3140 \\
\text { near ground level }\end{array}$} & Ann. Avg. & $7.92 \mathrm{E}-4$ & $9.32 \mathrm{E}-08$ \\
\hline & Highest $1 \mathrm{~h}$ & $5.92 \mathrm{E}-2$ & 6.97E-06 \\
\hline & Highest $3 \mathrm{~h}$ & $2.15 E-2$ & 2.54E-06 \\
\hline
\end{tabular}

Plots of effective dose computed from highest $1 \mathrm{~h}$ averages using the 2006 meteorology data are shown in Figs. 3-7 for sources S1-S5 respectively. Plots of effective dose computed from highest $1 \mathrm{~h}$ averages using the 2007 meteorology data are shown in Figs. 8-12 for sources S1-S5 respectively. Finally, plots of effective dose computed from highest $1 \mathrm{~h}$ averages using the 2008 meteorology data are shown in Figs. 13-17 for sources S1-S5 respectively.

To summarize our findings, of the five locations, S2 near ground level in building 3026D produced the highest dose, due to the release being at ground level and to the particular inventory of that building. The second highest dose was for S3 at the height of the maintenance roof in $3026 \mathrm{D}$, again due to the inventory, but reduced because a release at greater height will scatter material further downwind. The release at an even higher location (the roof level) at a point furthest removed from the sidewalk in front of 3026D results in even lower dose values, but above those of the other two locations (3026C and 3140 ). While air concentrations from the ground level release from building 3026C were high, the resulting doses were low since the activity of the inventory in building $3026 \mathrm{C}$ is 
substantially reduced below that in building 3026D according to the Preliminary Hazard Screening report. ${ }^{7}$ Finally, the dose computed from a unit release $(1 \mathrm{~g} / \mathrm{s})$ from filter house 3140 produced the lowest doses due to the inventory in that building.

In general the pattern of release showed higher effective doses toward the prevailing wind directions (along the valley), which also are parallel to the sidewalk along Central Avenue. In addition, doses were generally higher to the south of the complex of buildings due to building downwash effects and the presence of the hillside to the north. While care must be taken with all areas near the $3026 \mathrm{D} / \mathrm{C}$ complex, special care should be exercised to prevent exposure along the sidewalk in front of the 3026 complex and in occupied buildings that are across the street, south of the complex. 


\subsection{RESULTS FOR 2006 METEOROLOGY 1 H DATA}

\section{Results for S1 (Building 3026D - location is NW Corner at roof level)}

Table 7. Characteristics for S1

\begin{tabular}{|c|c|}
\hline \multicolumn{2}{|c|}{ Source Characteristics } \\
\hline UTM Easting & 742095.5 \\
UTM Northing & 3979226 \\
Elevation & $243.75 \mathrm{~m}$ \\
Height & $14.63 \mathrm{~m}$ \\
QS & $1 \mathrm{~g} / \mathrm{s}$ \\
Temp & $300 \mathrm{~K}$ \\
VS & $0.01 \mathrm{~m} / \mathrm{s}$ \\
DS & $4 \mathrm{~m}$ \\
\hline
\end{tabular}

Table 8. Maximum values for S1 highest $1 \mathrm{~h}$ results for 2006

\begin{tabular}{|ccc|}
\hline \multicolumn{3}{|c|}{ Maximum Results } \\
\hline & $\chi / Q\left(\mathrm{~s} / \mathrm{m}^{3}\right)$ & Dose(Sv) \\
AVG & $2.64 \mathrm{E}-4$ & $2.31 \mathrm{E}-02$ \\
HIGH 1HR & $5.37 \mathrm{E}-3$ & $4.69 \mathrm{E}-01$ \\
\hline
\end{tabular}

Summary of results: S1 was a high elevation (roof level) in a corner of building 3026D. The high elevation resulted in lower effective dose than occurred with locations near the ground level. For 2006 meteorology, the maximum annual average dispersion coefficient was $2.64 \mathrm{E}-4 \mathrm{~s} / \mathrm{m}^{3}$. Using the entire building inventory as if it were released in this location, the dose per unit release was computed to be $2.31 \mathrm{E}-2 \mathrm{~Sv}$ or $2.31 \mathrm{rem}$.

The limiting $1 \mathrm{~h}$ dispersion coefficient was $5.37 \mathrm{E}-3 \mathrm{~s} / \mathrm{m}^{3}$, which gave an effective dose of $0.469 \mathrm{~Sv}$ or $46.9 \mathrm{rem}$, given the radionuclide inventory for building 3026D. A release from S1 location in building 3026D would result in a large dose along the sidewalk and to buildings across the street to the south.

Note that doses are calculated assuming a complete release of the building inventory. To estimate the dose for a realistic release one should multiply the doses shown in Table 8 by a factor that represents the fraction of the building's inventory expected to be released. For example, assuming that one percent of the inventory in building 3026D is released, then the highest dose would be $0.469 \mathrm{~Sv} * 0.01$ or $0.469 \mathrm{rem}$. 


\section{Highest 1 h DOSE (Sv) for S1: Building 3026D - 2006 MET Data}
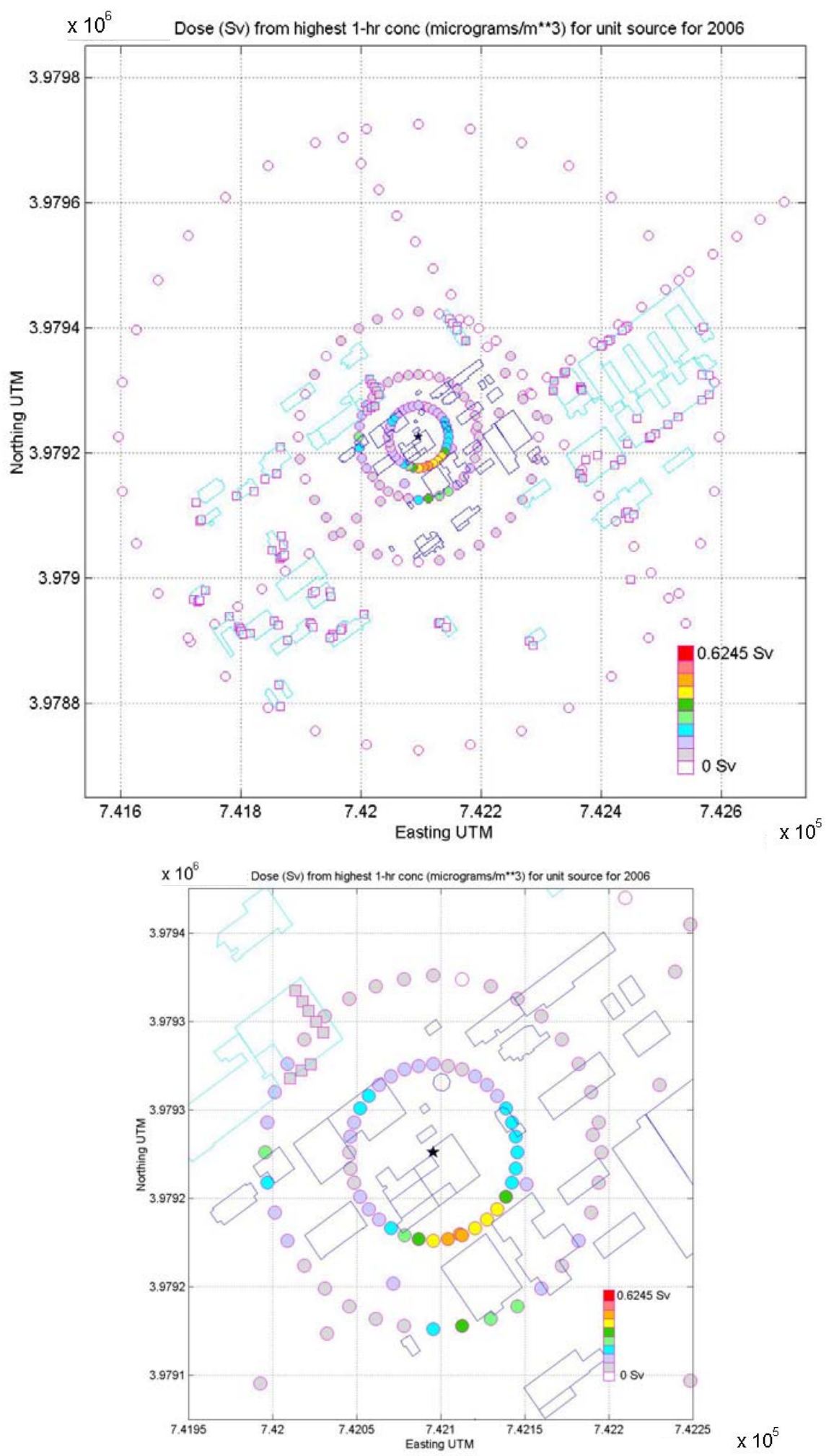

Fig. 3. Effective dose (Sv) for the limiting $1 \mathrm{~h}$ dispersion for S1 and 2006 meteorology. Shown are the entire study area (top) and view close in to source (bottom). 
Results for S2 (Building 3026D - location is center line, left side near ground level)

Table 9. Characteristics for S2

\begin{tabular}{|c|c|}
\hline \multicolumn{2}{|c|}{ Source Characteristics } \\
\hline UTM Easting & 742104 \\
UTM Northing & 3979215 \\
Elevation & 243.4 \\
Height & $1 \mathrm{~m}$ \\
QS & $1 \mathrm{~g} / \mathrm{s}$ \\
Temp & $300 \mathrm{~K}$ \\
VS & $0.01 \mathrm{~m} / \mathrm{s}$ \\
DS & $4 \mathrm{~m}$ \\
\hline
\end{tabular}

Table 10. Maximum values for $\mathrm{S} 2$ highest $1 \mathrm{~h}$ results for 2006

\begin{tabular}{|c|c|c|}
\hline \multicolumn{3}{|c|}{ Maximum Results } \\
\hline & $\chi / Q\left(\mathrm{~s} / \mathrm{m}^{3}\right)$ & Dose(Sv) \\
\hline AVG & 1.05E-3 & $9.14 \mathrm{E}-02$ \\
\hline $\mathrm{HIGH} 1 \mathrm{HR}$ & $7.60 \mathrm{E}-2$ & 6.63 \\
\hline
\end{tabular}

Summary of results: S2 was at floor level (1 meter above ground elevation) on the center line, left side of building 3026D. The low elevation and large value of the radionuclide activity in this building resulted in the highest doses of the five sources. The maximum annual average dispersion coefficient was $1.05 \mathrm{E}-3 \mathrm{~s} / \mathrm{m}^{3}$. Using the entire building inventory as if it were released in this location, the dose was computed to be 9.14E-2 Sv or 9.14 rem.

The limiting $1 \mathrm{~h}$ dispersion coefficient was $7.60 \mathrm{E}-2 \mathrm{~s} / \mathrm{m}^{3}$, which gave an effective dose of $6.63 \mathrm{~Sv}$ or $663 \mathrm{rem}$, given the radionuclide inventory for building 3026D. Compared with $\mathrm{S} 1$, a release from S2 location in building 3026D would result in a significantly larger dose along the sidewalk and to buildings across the street to the south.

Note that doses are calculated assuming a complete release of the building inventory. To estimate the dose for a realistic release one should multiply the doses shown in Table 10 by a factor that represents the fraction of the building's inventory expected to be released. For example, assuming that one percent of the inventory in building $3026 \mathrm{D}$ is released, then the highest dose would be $6.63 \mathrm{~Sv} * 0.01$ or $6.63 \mathrm{rem}$. 


\section{Highest 1 h DOSE (Sv) for S2: Building 3026D - 2006 MET Data}
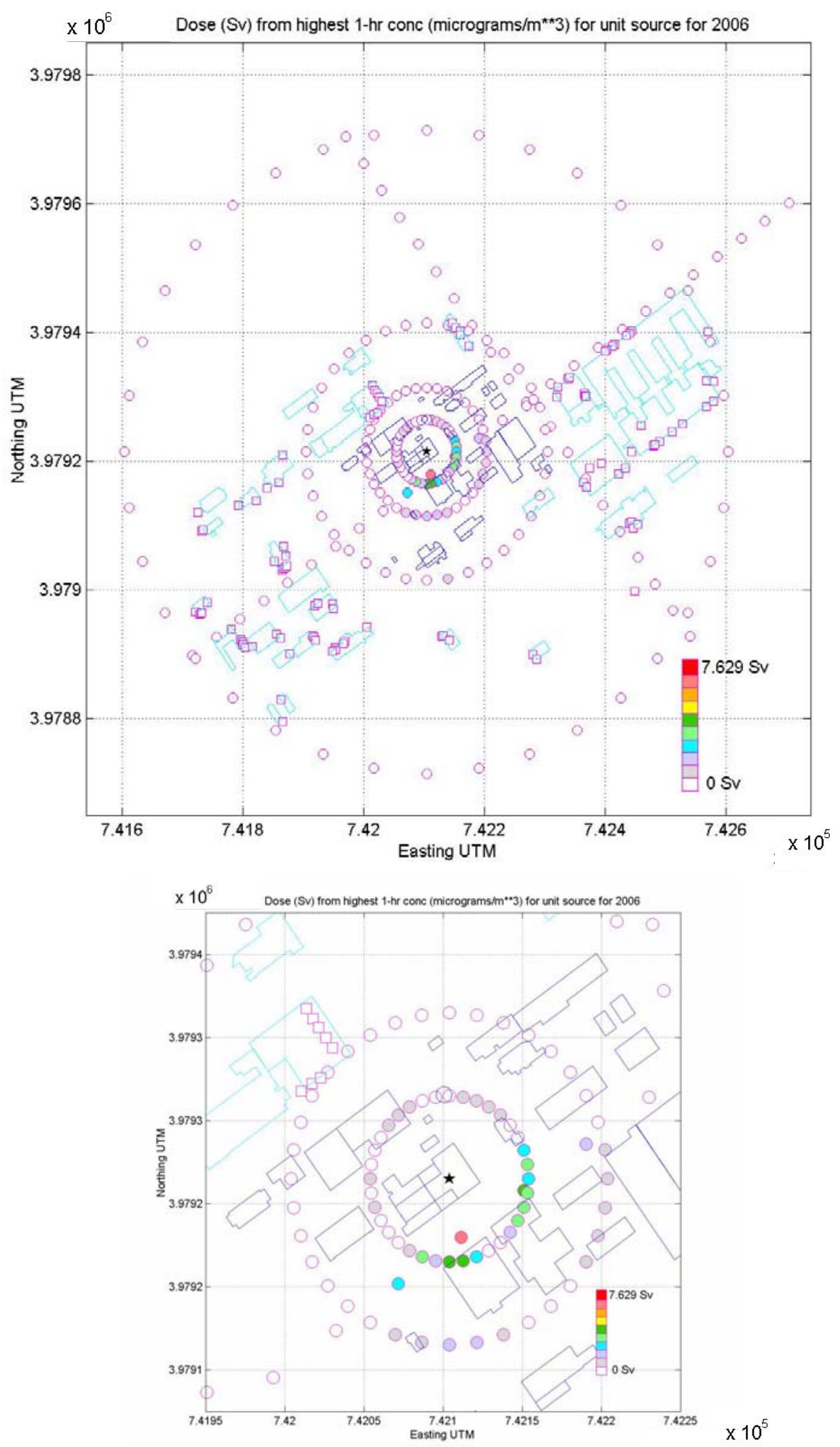

Fig. 4. Effective dose (Sv) for the limiting $1 \mathrm{~h}$ dispersion for S2 and 2006 meteorology. Shown are the entire study area (top) and view close in to source (bottom). 


\section{Results for S3 (Building 3026D - location is center line, above maintenance cubicle roof)}

Table 11. Characteristics for S3

\begin{tabular}{|c|c|}
\hline \multicolumn{2}{|c|}{ Source Characteristics } \\
\hline UTM Easting & 742111 \\
UTM Northing & 3979221 \\
Elevation & $243.41 \mathrm{~m}$ \\
Height & $12 \mathrm{~m}$ \\
QS & $1 \mathrm{~g} / \mathrm{s}$ \\
Temp & $300 \mathrm{~K}$ \\
VS & $0.01 \mathrm{~m} / \mathrm{s}$ \\
DS & $4 \mathrm{~m}$ \\
\hline
\end{tabular}

Table 12. Maximum values for S3 highest $1 \mathrm{~h}$ results for 2006

\begin{tabular}{|c|c|c|}
\hline \multicolumn{3}{|c|}{ Maximum Results } \\
\hline & $\chi / Q\left(\mathrm{~s} / \mathrm{m}^{3}\right.$ & Dose(Sv) \\
\hline AVG & $7.08 \mathrm{E}-4$ & $6.17 \mathrm{E}-02$ \\
\hline $\mathrm{HIGH} 1 \mathrm{HR}$ & $1.31 \mathrm{E}-2$ & 1.15 \\
\hline
\end{tabular}

Summary of results: S3 center line above the maintenance cubicle roof in building 3026D. The maintenance cubicle is a work area above the hot cells that allowed equipment and personnel access to the hot cells from above. The higher elevation of S3 combined with the large value of the radionuclide activity in this building resulted in the higher dose of the first source. The maximum annual average dispersion coefficient was $7.08 \mathrm{E}-4 \mathrm{~s} / \mathrm{m}^{3}$. Using the entire building inventory as if it were released in this location, the dose was computed to be $6.17 \mathrm{E}-02 \mathrm{~Sv}$ or $6.17 \mathrm{rem}$.

The limiting $1 \mathrm{~h}$ dispersion coefficient was $1.31 \mathrm{E}-2 \mathrm{~s} / \mathrm{m}^{3}$, which gave an effective dose of $1.51 \mathrm{~Sv}$ or $151 \mathrm{rem}$, given the radionuclide inventory for building 3026D.

Note that doses are calculated assuming a complete release of the building inventory. To estimate the dose for a realistic release one should multiply the doses shown in Table 12 by a factor that represents the fraction of the building's inventory expected to be released. For example, assuming that one percent of the inventory in building 3026D is released, then the highest dose would be $1.15 \mathrm{~Sv} * 0.01$ or $1.15 \mathrm{rem}$. 
Highest 1 h DOSE (Sv) for S3: Building 3026D - 2006 MET Data
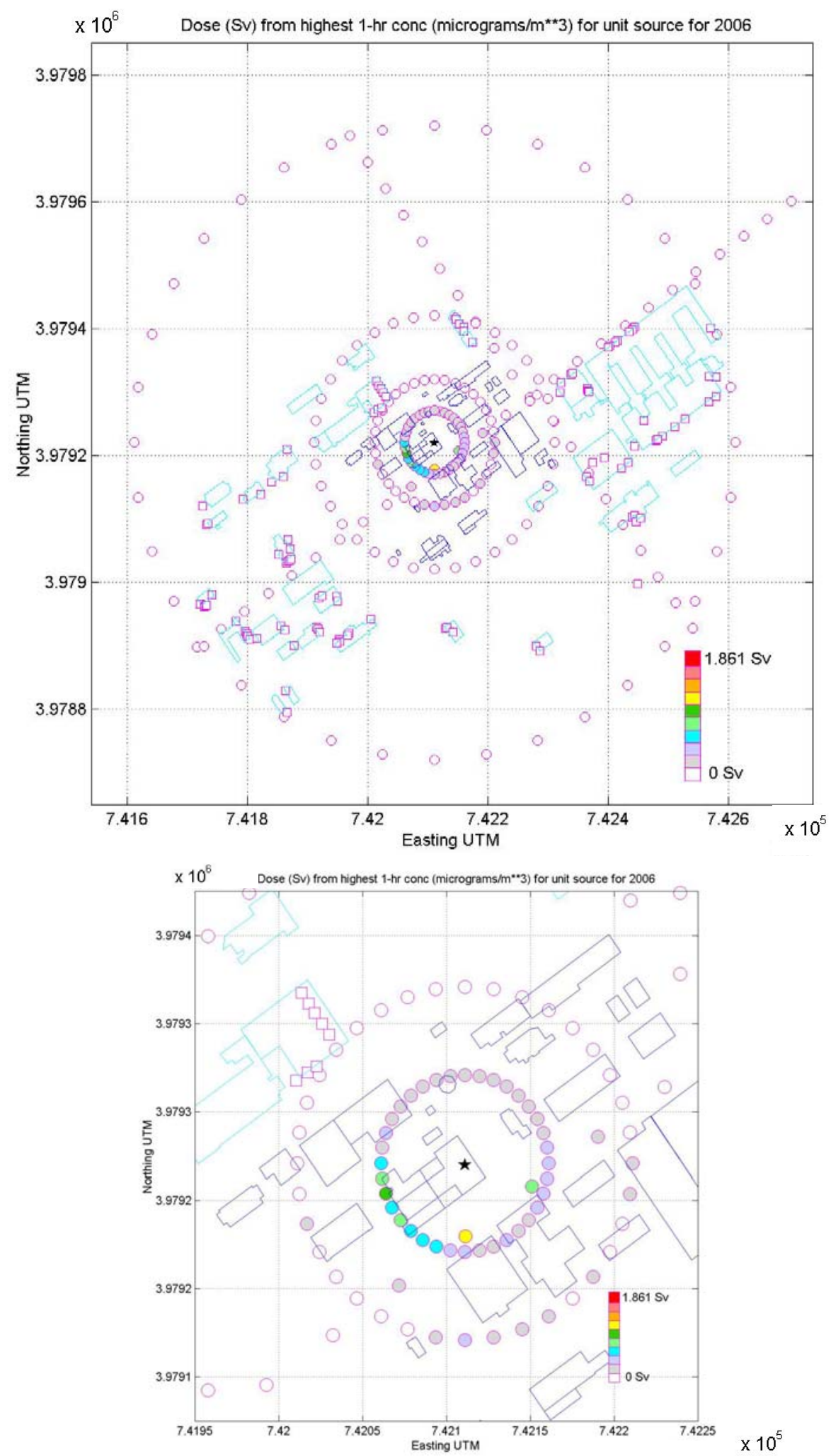

Fig. 5. Effective dose (Sv) for the limiting $1 \mathrm{~h}$ dispersion for S3 and 2006 meteorology. Shown are the entire study area (top) and view close in to source (bottom). 


\section{Results for S4 (Building 3026C - location is NW side near ground level)}

Table 13. Characteristics for S4

\begin{tabular}{|c|c|}
\hline \multicolumn{2}{|c|}{ Source Characteristics } \\
\hline UTM Easting & 742080 \\
UTM Northing & 3979209 \\
Elevation & 243.49 \\
Height & $1 \mathrm{~m}$ \\
QS & $1 \mathrm{~g} / \mathrm{s}$ \\
Temp & $300 \mathrm{~K}$ \\
VS & $0.01 \mathrm{~m} / \mathrm{s}$ \\
DS & $4 \mathrm{~m}$ \\
\hline
\end{tabular}

Table 14. Maximum values for S4 highest $1 \mathrm{~h}$ results for 2006

\begin{tabular}{|c|c|c|}
\hline \multicolumn{3}{|c|}{ Maximum Results } \\
\hline & $\chi / Q\left(\mathrm{~s} / \mathrm{m}^{3}\right)$ & Dose(Sv) \\
\hline AVG & 1.10E-3 & 1.5E-04 \\
\hline HIGH $1 \mathrm{HR}$ & $3.80 \mathrm{E}-2$ & $5.18 \mathrm{E}-03$ \\
\hline
\end{tabular}

Summary of results: S4 is located on the NW side building 3026C at floor level $(1 \mathrm{~m}$ above ground elevation). The low elevation resulted in high dispersion coefficients but the relatively small value of the radionuclide activity in this building resulted in the second lowest doses of the five sources. The maximum annual average dispersion coefficient was $1.10 \mathrm{E}-3 \mathrm{~s} / \mathrm{m}^{3}$. Using the entire building inventory as if it were released in this location, the dose was computed to be $1.5 \mathrm{E}-04 \mathrm{~Sv}$ or $0.015 \mathrm{rem}$.

The limiting $1 \mathrm{~h}$ dispersion coefficient was $3.80 \mathrm{E}-2 \mathrm{~s} / \mathrm{m}^{3}$, which gave an effective dose of $5.18 \mathrm{E}-03 \mathrm{~Sv}$ or $0.518 \mathrm{rem}$, given the radionuclide inventory for building 3026C. While the dispersion coefficients are high, the inventory in building $3026 \mathrm{C}$ results in very low doses.

Note that doses are calculated assuming a complete release of the building inventory. To estimate the dose for a realistic release one should multiply the doses shown in Table 14 by a factor that represents the fraction of the building's inventory expected to be released. For example, assuming that one percent of the inventory in building $3026 \mathrm{C}$ is released, then the highest dose would be $5.18 \mathrm{E}-3 \mathrm{~Sv} * 0.01$ or $5.18 \mathrm{E}-3 \mathrm{rem}$. 

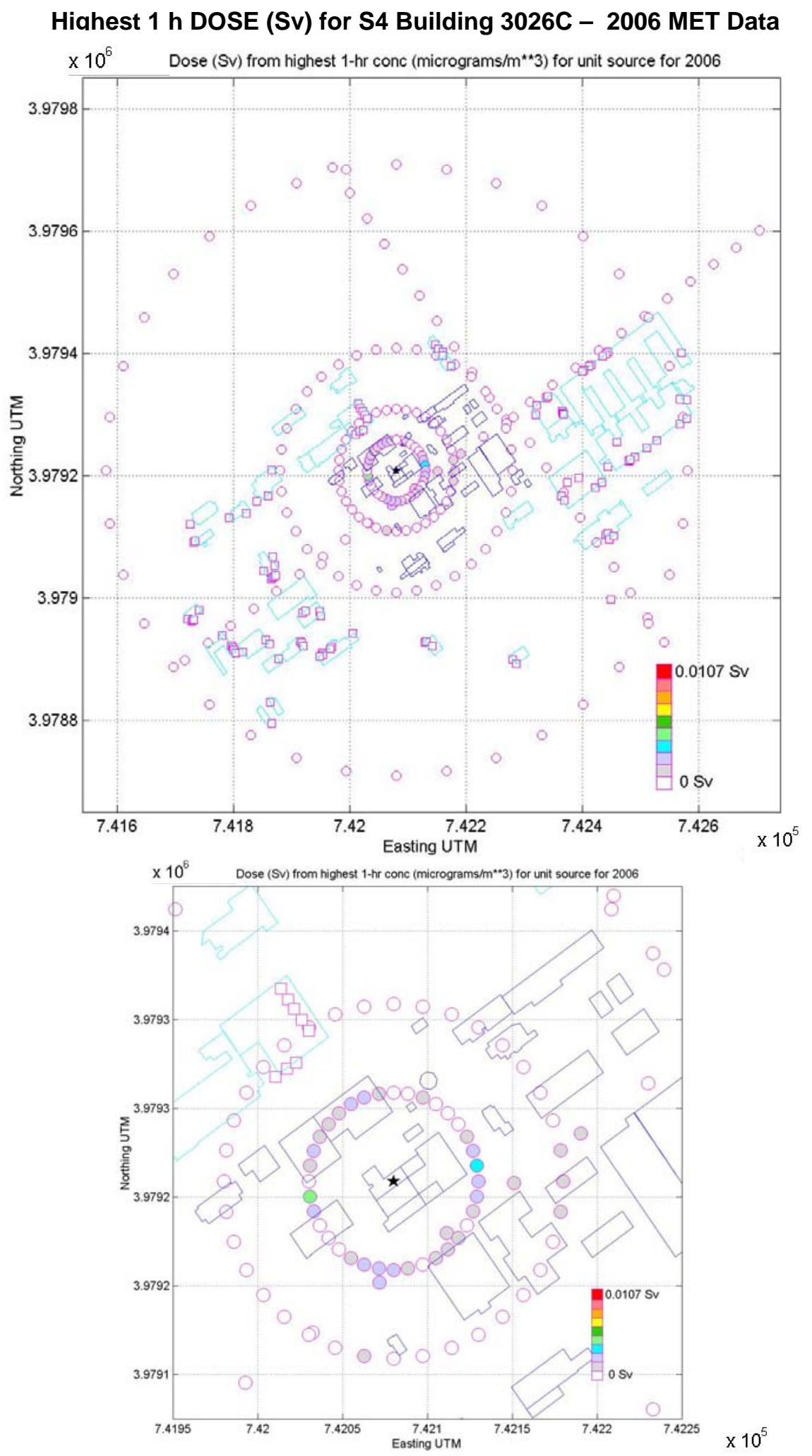

Fig. 6. Effective dose (Sv) for the limiting $1 \mathrm{~h}$ dispersion for S4 and 2006 meteorology. Shown are the entire study area (top) and view close in to source (bottom). 


\section{Results for S5 (Building 3140 - location is center of building near ground level)}

Table 15. Characteristics for S5

\begin{tabular}{|c|c|}
\hline \multicolumn{2}{|c|}{ Source Characteristics } \\
\hline UTM Easting & 742090.5 \\
UTM Northing & 3979250.8 \\
Elevation & $244.69 \mathrm{~m}$ \\
Height & $1 \mathrm{~m}$ \\
QS & $1 \mathrm{~g} / \mathrm{s}$ \\
Temp & $300 \mathrm{~K}$ \\
VS & $0.01 \mathrm{~m} / \mathrm{s}$ \\
DS & $4 \mathrm{~m}$ \\
\hline
\end{tabular}

Table 16. Maximum values for S5 highest $1 \mathrm{~h}$ results for 2006

\begin{tabular}{|ccc|}
\hline \multicolumn{3}{|c|}{ Maximum Results } \\
\hline & $\chi / \mathrm{Q}\left(\mathrm{s} / \mathrm{m}^{3}\right)$ & Dose(Sv) \\
AVG & $6.53 \mathrm{E}-4$ & $7.68 \mathrm{E}-08$ \\
HIGH 1HR & $2.01 \mathrm{E}-2$ & $2.37 \mathrm{E}-06$ \\
\hline
\end{tabular}

Summary of results: S5 is located in the center of the filter house 3140 at floor level ( $1 \mathrm{~m}$ above ground elevation). The low elevation and small value of the radionuclide activity in this building resulted in the lowest doses of the five sources. The maximum annual average dispersion coefficient was $6.53 \mathrm{E}-4 \mathrm{~s} / \mathrm{m}^{3}$. Using the entire building inventory as if it were released in this location, the dose was computed to be $7.68 \mathrm{E}-08 \mathrm{~Sv}$ or $7.68 \mathrm{E}-6$ rem.

The limiting $1 \mathrm{~h}$ dispersion coefficient was $2.01 \mathrm{E}-2 \mathrm{~s} / \mathrm{m}^{3}$, which gave an effective dose of 2.37E-06 Sv or 2.37E-04 rem, given the radionuclide inventory for filter house 3140 . The combination of low dispersion coefficients and the inventory in the filter house 3140 results in extremely low doses.

Note that doses are calculated assuming a complete release of the building inventory. To estimate the dose for a realistic release one should multiply the doses shown in Table 16 by a factor that represents the fraction of the building's inventory expected to be released. For example, assuming that fifty percent of the inventory in filter house 3140 is released, then the highest dose would be $2.37 \mathrm{E}-06 \mathrm{~Sv} * 0.5$ or $1.19 \mathrm{E}-04 \mathrm{rem}$. 


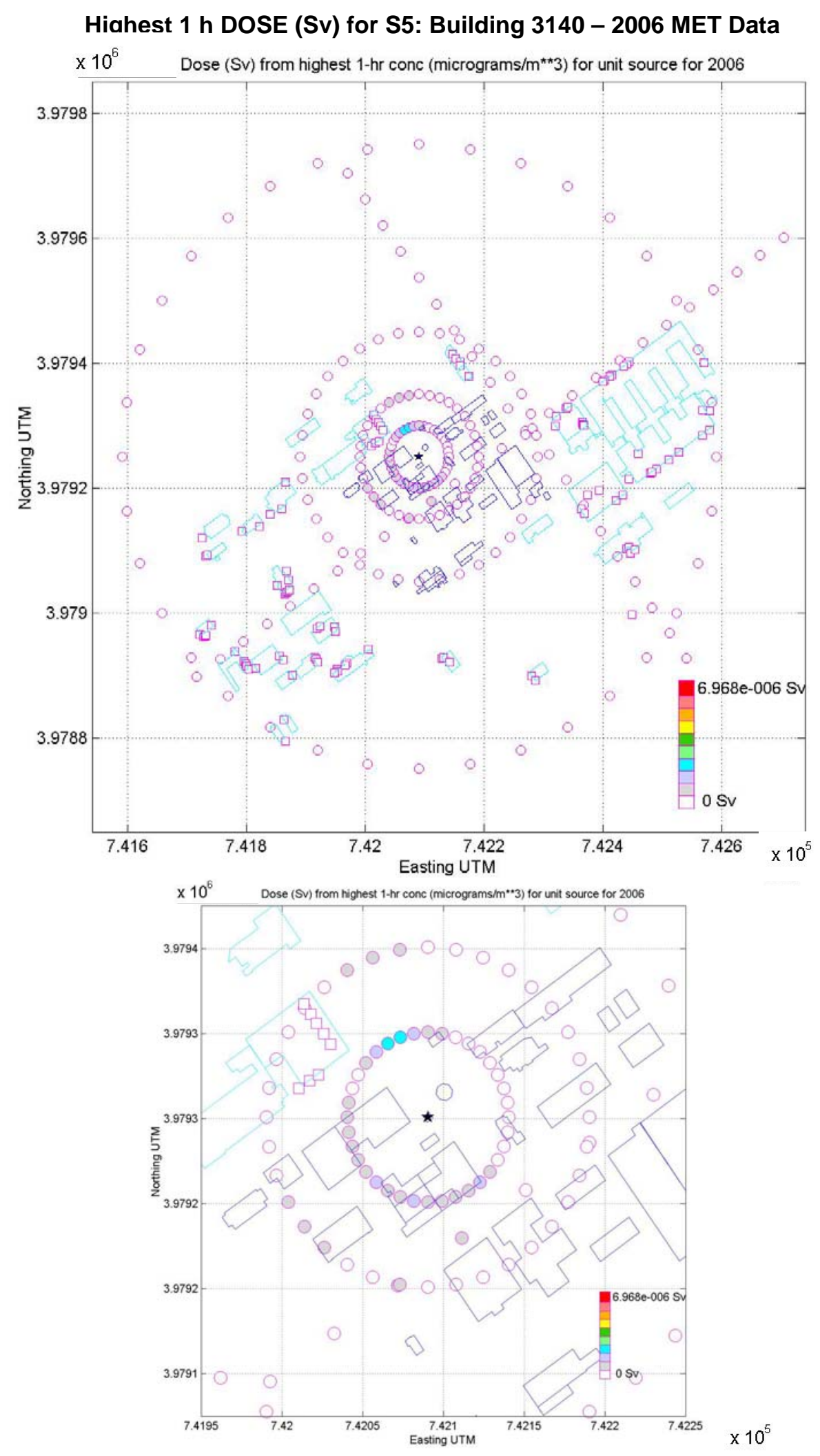

Fig. 7. Effective dose (Sv) for the limiting $1 \mathrm{~h}$ dispersion for S5 and 2006 meteorology. Shown are the entire study area (top) and view close in to source (bottom). 


\subsection{RESULTS FOR 2007 METEOROLOGY 1 H DATA}

\section{Results for S1 (Building 3026D - location is NW Corner at roof level)}

Table 17. Characteristics for S1

\begin{tabular}{|c|c|}
\hline \multicolumn{2}{|c|}{ Source Characteristics } \\
\hline UTM Easting & 742095.5 \\
UTM Northing & 3979226 \\
Elevation & $243.75 \mathrm{~m}$ \\
Height & $14.63 \mathrm{~m}$ \\
QS & $1 \mathrm{~g} / \mathrm{s}$ \\
Temp & $300 \mathrm{~K}$ \\
VS & $0.01 \mathrm{~m} / \mathrm{s}$ \\
DS & $4 \mathrm{~m}$ \\
\hline
\end{tabular}

Table 18. Maximum values for S1 highest $1 \mathrm{~h}$ results for 2007

\begin{tabular}{|ccc|}
\hline \multicolumn{3}{|c|}{ Maximum Results } \\
\hline & $\chi / \mathrm{Q}\left(\mathrm{s} / \mathrm{m}^{3}\right)$ & Dose(Sv) \\
AVG & $3.06 \mathrm{E}-4$ & $2.67 \mathrm{E}-02$ \\
$\mathrm{HIGH} 1 \mathrm{HR}$ & $7.16 \mathrm{E}-3$ & $6.25 \mathrm{E}-01$ \\
\hline
\end{tabular}

Summary of results: S1 was a high elevation (roof level) in a corner of building 3026D. The high elevation resulted in much lower doses that occurred with locations near the ground level. The maximum annual average dispersion coefficient was $3.06 \mathrm{E}-4 \mathrm{~s} / \mathrm{m}^{3}$. Using the entire building inventory as if it were released in this location, the dose was computed to be $2.67 \mathrm{E}-2 \mathrm{~Sv}$ or $2.67 \mathrm{rem}$.

The limiting $1 \mathrm{~h}$ dispersion coefficient was $7.16 \mathrm{E}-3 \mathrm{~s} / \mathrm{m}^{3}$, which gave an effective dose of $0.625 \mathrm{~Sv}$ or $62.5 \mathrm{rem}$, given the radionuclide inventory for building 3026D. A release from S1 location in building 3026D would result in a large dose along the sidewalk and to buildings across the street to the south.

Note that doses are calculated assuming a complete release of the building inventory. To estimate the dose for a realistic release one should multiply the doses shown in Table 18 by a factor that represents the fraction of the building's inventory expected to be released. For example, assuming that one percent of the inventory in building 3026D is released, then the highest dose would be $0.625 \mathrm{~Sv} * 0.01$ or $0.625 \mathrm{rem}$. 
Hiahest 1 h DOSE (Sv) for S1: Building 3026D - 2007 MET Data
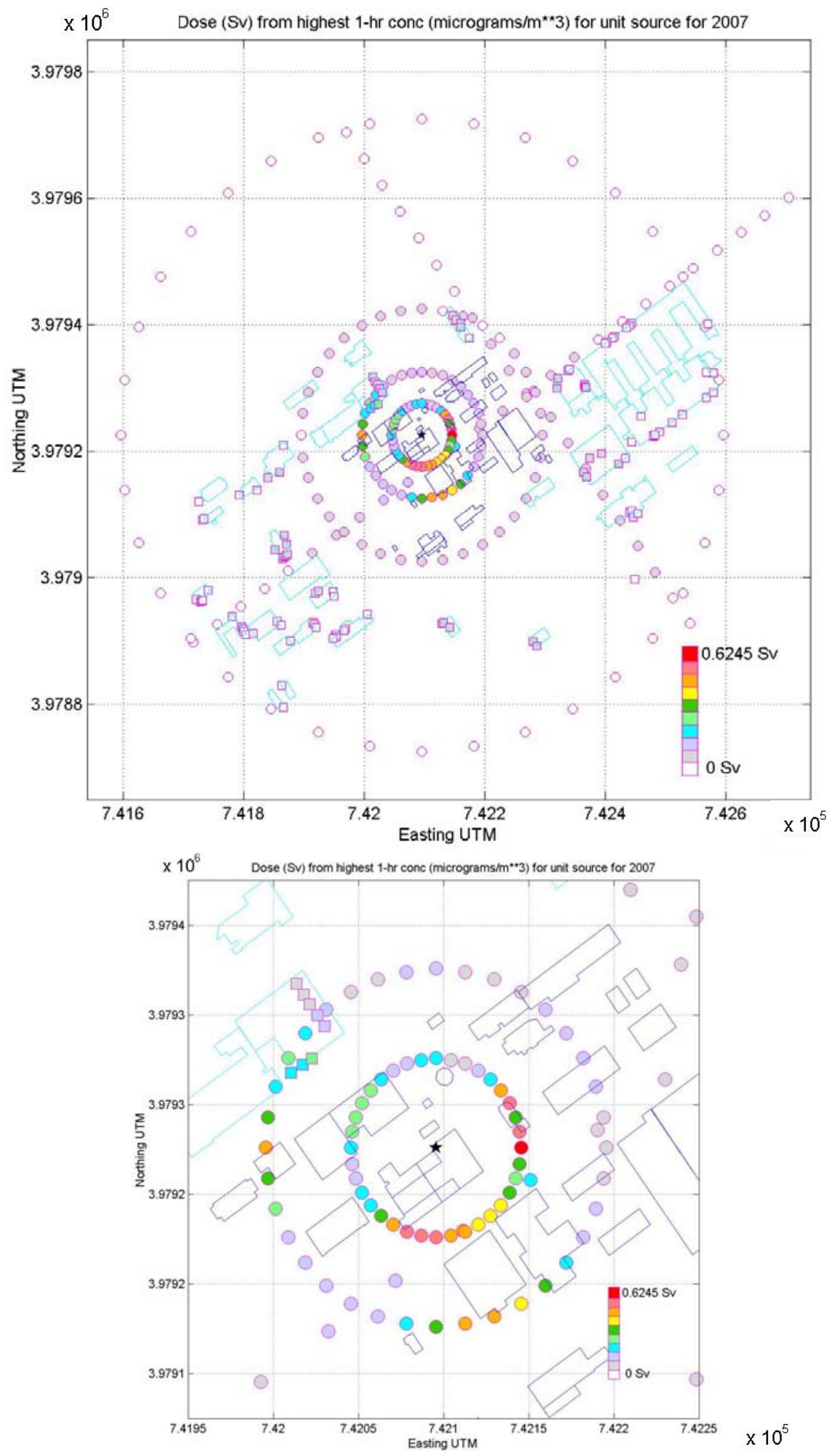

Fig. 8. Effective dose (Sv) for the limiting $1 \mathrm{~h}$ dispersion for S1 and 2007 meteorology. Shown are the entire study area (top) and view close in to source (bottom). 


\section{Results for S2 (Building 3026D - location is center line, left side near ground level)}

Table 19. Characteristics for S2

\begin{tabular}{|c|c|}
\hline \multicolumn{2}{|c|}{ Source Characteristics } \\
\hline UTM Easting & 742104 \\
UTM Northing & 3979215 \\
Elevation & 243.4 \\
Height & $1 \mathrm{~m}$ \\
QS & $1 \mathrm{~g} / \mathrm{s}$ \\
Temp & $300 \mathrm{~K}$ \\
VS & $0.01 \mathrm{~m} / \mathrm{s}$ \\
DS & $4 \mathrm{~m}$ \\
\hline
\end{tabular}

Table 20. Maximum values for S2 highest 1 h results for 2007

\begin{tabular}{|c|c|c|}
\hline \multicolumn{3}{|c|}{ Maximum Results } \\
\hline & $\chi / Q\left(\mathrm{~s} / \mathrm{m}^{3}\right)$ & Dose(Sv) \\
\hline AVG & 1.10E-3 & 9.57E-02 \\
\hline $\mathrm{HIGH} 1 \mathrm{HR}$ & 7.10E-2 & 6.19 \\
\hline
\end{tabular}

Summary of results: S2 was at floor level (1 m above ground elevation) on the center line, left side of building 3026D. The low elevation and large value of the radionuclide activity in this building resulted in the highest doses of the five sources. The maximum annual average dispersion coefficient was $1.10 \mathrm{E}-3 \mathrm{~s} / \mathrm{m}^{3}$. Using the entire building inventory as if it were released in this location, the dose was computed to be $9.57 \mathrm{E}-2 \mathrm{~Sv}$ or 9.57 rem.

The limiting $1 \mathrm{~h}$ dispersion coefficient was $7.10 \mathrm{E}-2 \mathrm{~s} / \mathrm{m}^{3}$, which gave an effective dose of 6.19 Sv or 619 rem, given the radionuclide inventory for building 3026D. Compared with $\mathrm{S} 1$, a release from S2 location in building 3026D would result in a significantly larger dose along the sidewalk and to buildings across the street to the south.

Note that doses are calculated assuming a complete release of the building inventory. To estimate the dose for a realistic release one should multiply the doses shown in Table 20 by a factor that represents the fraction of the building's inventory expected to be released. For example, assuming that one percent of the inventory in building $3026 \mathrm{D}$ is released, then the highest dose would be $6.19 \mathrm{~Sv} * 0.01$ or $6.19 \mathrm{rem}$. 


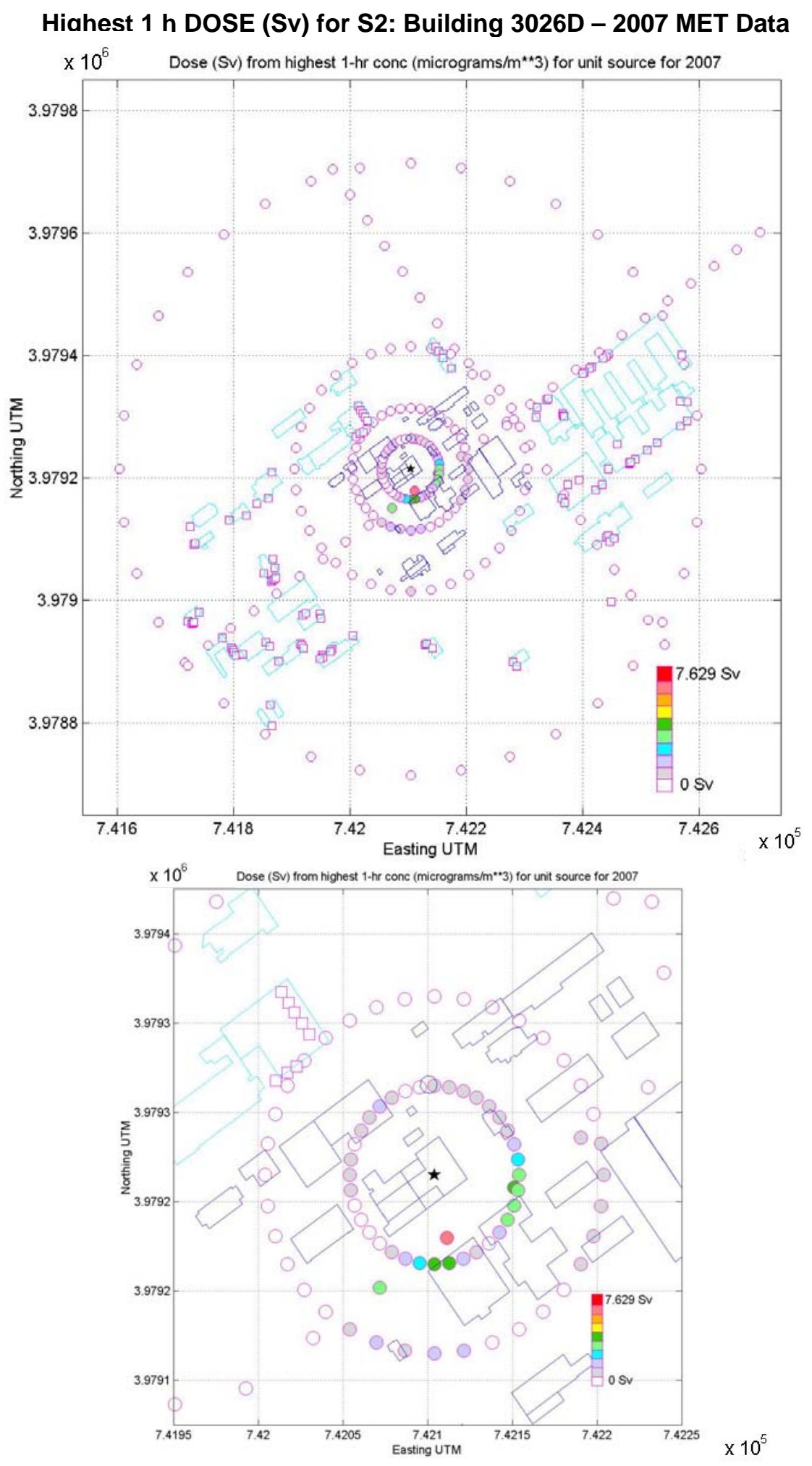

Fig. 9. Effective dose (Sv) for the limiting $1 \mathrm{~h}$ dispersion for S2 and 2007 meteorology. Shown are the entire study area (top) and view close in to source (bottom). 


\section{Results for S3 (Building 3026D - location is center line, above maintenance cubicle roof)}

Table 21. Characteristics for S3

\begin{tabular}{|c|c|}
\hline \multicolumn{2}{|c|}{ Source Characteristics } \\
\hline UTM Easting & 742111 \\
UTM Northing & 3979221 \\
Elevation & $243.41 \mathrm{~m}$ \\
Height & $12 \mathrm{~m}$ \\
QS & $1 \mathrm{~g} / \mathrm{s}$ \\
Temp & $300 \mathrm{~K}$ \\
VS & $0.01 \mathrm{~m} / \mathrm{s}$ \\
DS & $4 \mathrm{~m}$ \\
\hline
\end{tabular}

Table 22. Maximum values for S3 highest $1 \mathrm{~h}$ results for 2007

\begin{tabular}{|c|c|c|}
\hline \multicolumn{3}{|c|}{ Maximum Results } \\
\hline & $\chi / Q\left(\mathrm{~s} / \mathrm{m}^{3}\right)$ & Dose(Sv) \\
\hline AVG & 8.88E-4 & 7.75E-02 \\
\hline $\mathrm{HIGH} 1 \mathrm{HR}$ & 1.66E-2 & 1.45 \\
\hline
\end{tabular}

Summary of results: S3 center line above the maintenance roof in building 3026D. The higher elevation of S3 combined with the large value of the radionuclide activity in this building resulted in the higher dose of the first source. The maximum annual average dispersion coefficient was $8.88 \mathrm{E}-4 \mathrm{~s} / \mathrm{m}^{3}$. Using the entire building inventory as if it were released in this location, the dose was computed to be $7.75 \mathrm{E}-02 \mathrm{~Sv}$ or $7.75 \mathrm{rem}$.

The limiting $1 \mathrm{~h}$ dispersion coefficient was $1.66 \mathrm{E}-2 \mathrm{~s} / \mathrm{m}^{3}$, which gave an effective dose of $1.45 \mathrm{~Sv}$ or $145 \mathrm{rem}$, given the radionuclide inventory for building 3026D.

Note that doses are calculated assuming a complete release of the building inventory. To estimate the dose for a realistic release one should multiply the doses shown in Table 22 by a factor that represents the fraction of the building's inventory expected to be released. For example, assuming that one percent of the inventory in building 3026D is released, then the highest dose would be $1.45 \mathrm{~Sv} * 0.01$ or $1.45 \mathrm{rem}$. 


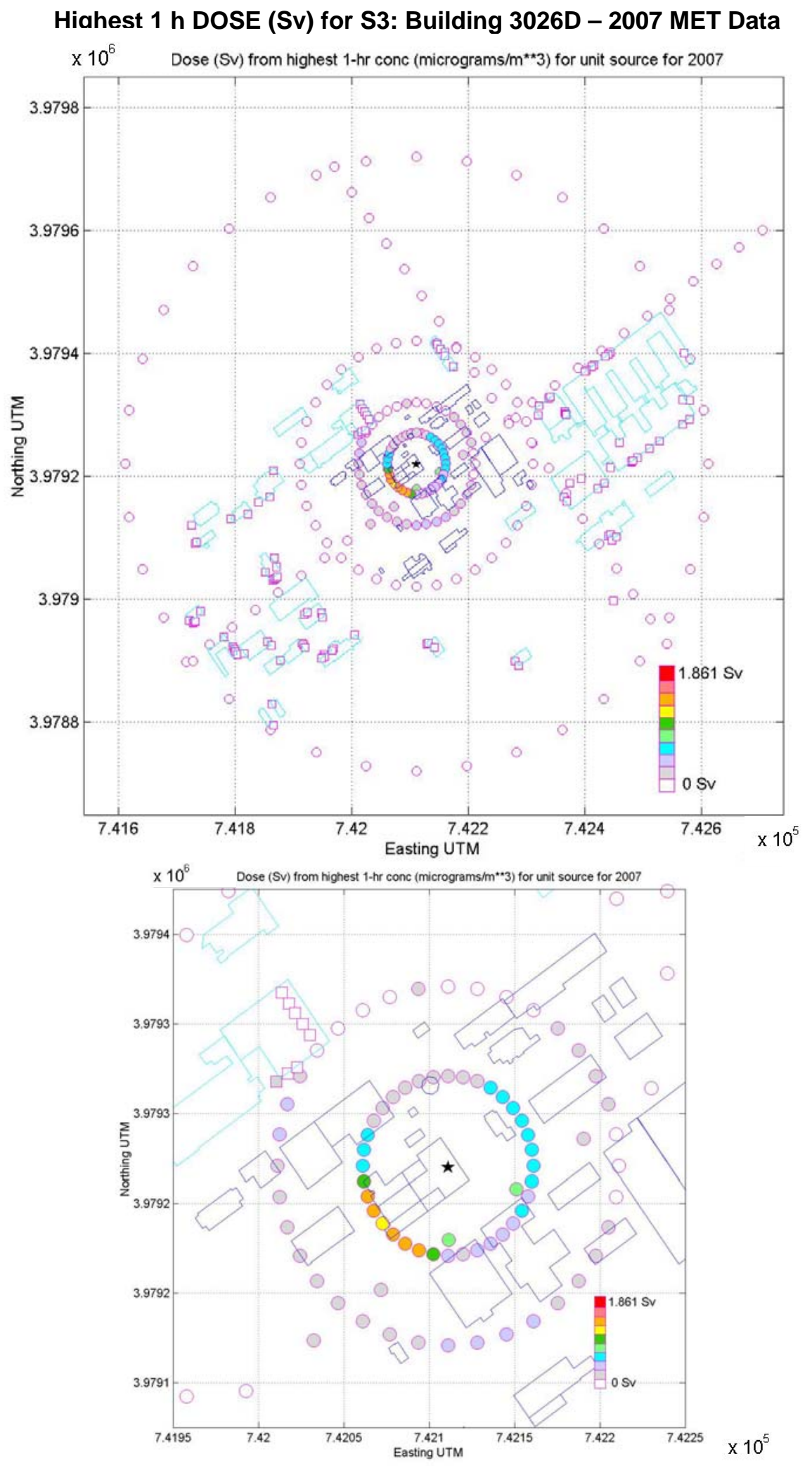

Fig. 10. Effective dose (Sv) for the limiting $1 \mathrm{~h}$ dispersion for S3 and 2007 meteorology. Shown are the entire study area (top) and view close in to source (bottom). 


\section{Results for S4 (Building 3026C - location is NW side near ground level)}

Table 23. Characteristics for S4

\begin{tabular}{|c|c|}
\hline \multicolumn{2}{|c|}{ Source Characteristics } \\
\hline UTM Easting & 742080 \\
UTM Northing & 3979209 \\
Elevation & 243.49 \\
Height & $1 \mathrm{~m}$ \\
QS & $1 \mathrm{~g} / \mathrm{s}$ \\
Temp & $300 \mathrm{~K}$ \\
VS & $0.01 \mathrm{~m} / \mathrm{s}$ \\
DS & $4 \mathrm{~m}$ \\
\hline
\end{tabular}

Table 24. Maximum values for S4 highest $1 \mathrm{~h}$ results for 2007

\begin{tabular}{|ccc|}
\hline \multicolumn{3}{|c|}{ Maximum Results } \\
\hline & $\chi / \mathrm{Q}\left(\mathrm{s} / \mathrm{m}^{3}\right)$ & Dose(Sv) \\
AVG & $1.16 \mathrm{E}-3$ & $1.58 \mathrm{E}-04$ \\
HIGH 1HR & $3.67 \mathrm{E}-2$ & $5.0 \mathrm{E}-03$ \\
\hline
\end{tabular}

Summary of results: S4 is located on the NW side building 3026C at floor level $(1 \mathrm{~m}$ above ground elevation). The low elevation resulted in high dispersion coefficients, but the relatively small value of the radionuclide activity in this building resulted in the second lowest doses of the five sources. The maximum annual average dispersion coefficient was $1.16 \mathrm{E}-3 \mathrm{~s} / \mathrm{m}^{3}$. Using the entire building inventory as if it were released in this location, the dose was computed to be $1.58 \mathrm{E}-4 \mathrm{~Sv}$ or $0.0158 \mathrm{rem}$.

The limiting $1 \mathrm{~h}$ dispersion coefficient was $3.67 \mathrm{E}-2 \mathrm{~s} / \mathrm{m}^{3}$, which gave an effective dose of $5.0 \mathrm{E}-03 \mathrm{~Sv}$ or $0.5 \mathrm{rem}$, given the radionuclide inventory for building $3026 \mathrm{C}$. While the dispersion coefficients are high, the inventory in building $3026 \mathrm{C}$ results in very low doses.

Note that doses are calculated assuming a complete release of the building inventory. To estimate the dose for a realistic release one should multiply the doses shown in Table 24 by a factor that represents the fraction of the building's inventory expected to be released. For example, assuming that one percent of the inventory in building 3026C is released, then the highest dose would be $5.0 \mathrm{E}-03 \mathrm{~Sv} * 0.01$ or $5.0 \mathrm{E}-03$ rem 

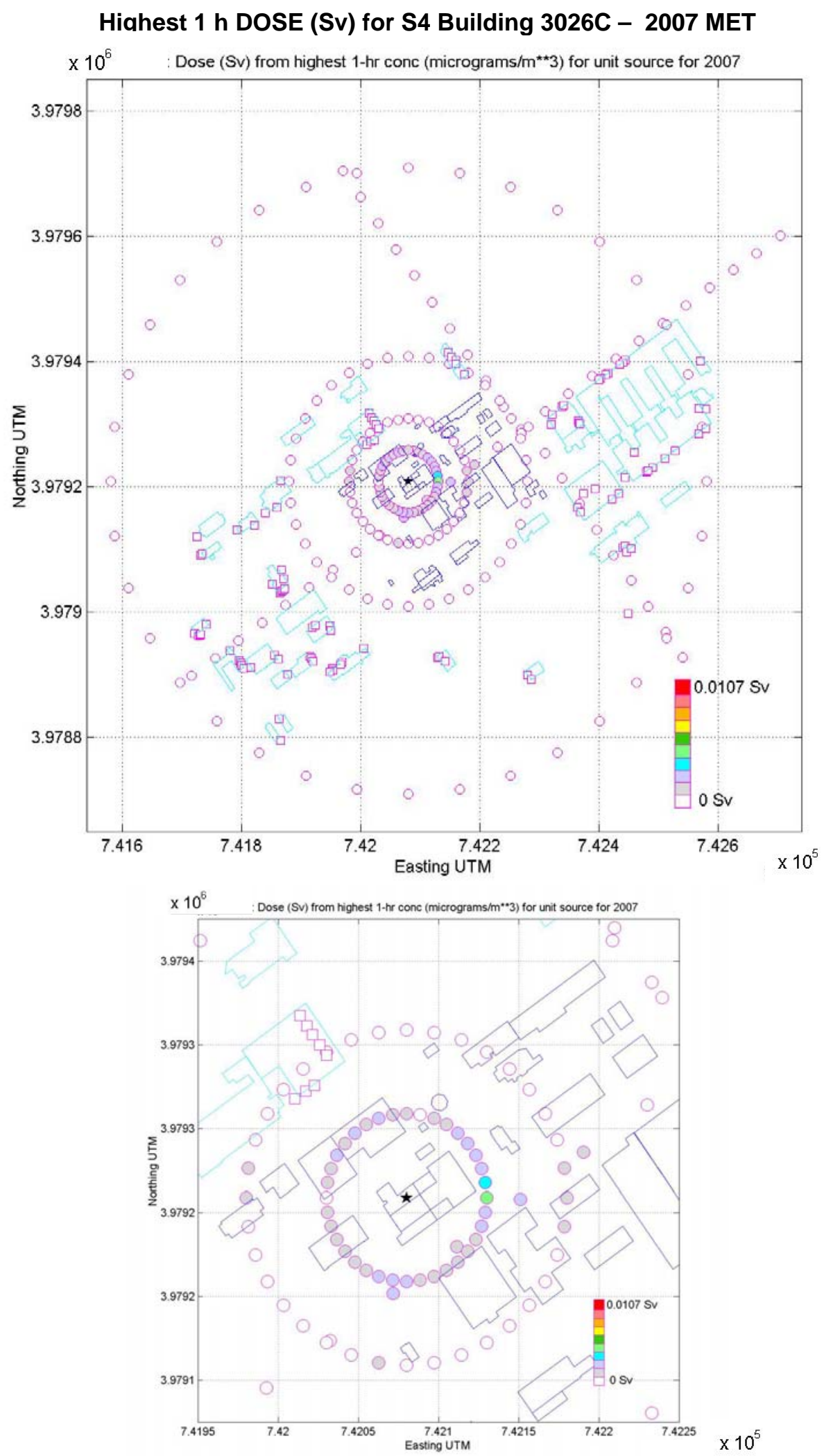

Fig. 11. Effective dose (Sv) for the limiting $1 \mathrm{~h}$ dispersion for S4 and 2007 meteorology. Shown are the entire study area (top) and view close in to source (bottom). 


\section{Results for S5 (Building 3140 - location is center of building near ground level)}

Table 25. Characteristics for S5

\begin{tabular}{|c|c|}
\hline \multicolumn{2}{|c|}{ Source Characteristics } \\
\hline UTM Easting & 742090.5 \\
UTM Northing & 3979250.8 \\
Elevation & $244.69 \mathrm{~m}$ \\
Height & $1 \mathrm{~m}$ \\
QS & $1 \mathrm{~g} / \mathrm{s}$ \\
Temp & $300 \mathrm{~K}$ \\
VS & $0.01 \mathrm{~m} / \mathrm{s}$ \\
DS & $4 \mathrm{~m}$ \\
\hline
\end{tabular}

Table 26. Maximum values for S5

highest $1 \mathrm{~h}$ results for 2007

\begin{tabular}{|ccc|}
\hline \multicolumn{3}{|c|}{ Maximum Results } \\
\hline & $\chi / \mathrm{Q}\left(\mathrm{s} / \mathrm{m}^{3}\right)$ & Dose(Sv) \\
AVG & $7.92 \mathrm{E}-4$ & $9.32 \mathrm{E}-08$ \\
HIGH 1HR & $2.24 \mathrm{E}-2$ & $2.64 \mathrm{E}-06$ \\
\hline
\end{tabular}

Summary of results: S5 is located in the center of filter house 3140 at floor level ( $1 \mathrm{~m}$ above ground elevation). The low elevation and small value of the radionuclide activity in this building resulted in the lowest doses of the five sources. The maximum annual average dispersion coefficient was $7.92 \mathrm{E}-4 \mathrm{~s} / \mathrm{m}^{3}$. Using the entire building inventory as if it were released in this location, the dose was computed to be $9.32 \mathrm{E}-08 \mathrm{~Sv}$ or 9.32E-6 rem.

The limiting $1 \mathrm{~h}$ dispersion coefficient was $2.24 \mathrm{E}-2 \mathrm{~s} / \mathrm{m}^{3}$, which gave an effective dose of 2.64E-06 Sv or 2.64E-04 rem, given the radionuclide inventory for filter house 3140 . The combination of low dispersion coefficients and the inventory in the filter house 3140 results in extremely low doses.

Note that doses are calculated assuming a complete release of the building inventory. To estimate the dose for a realistic release one should multiply the doses shown in Table 26 by a factor that represents the fraction of the building's inventory expected to be released. For example, assuming that fifty percent of the inventory in filter house 3140 is released, then the highest dose would be $2.64 \mathrm{E}-06 \mathrm{~Sv} * 0.5$ or $1.32 \mathrm{E}-04$ rem. 

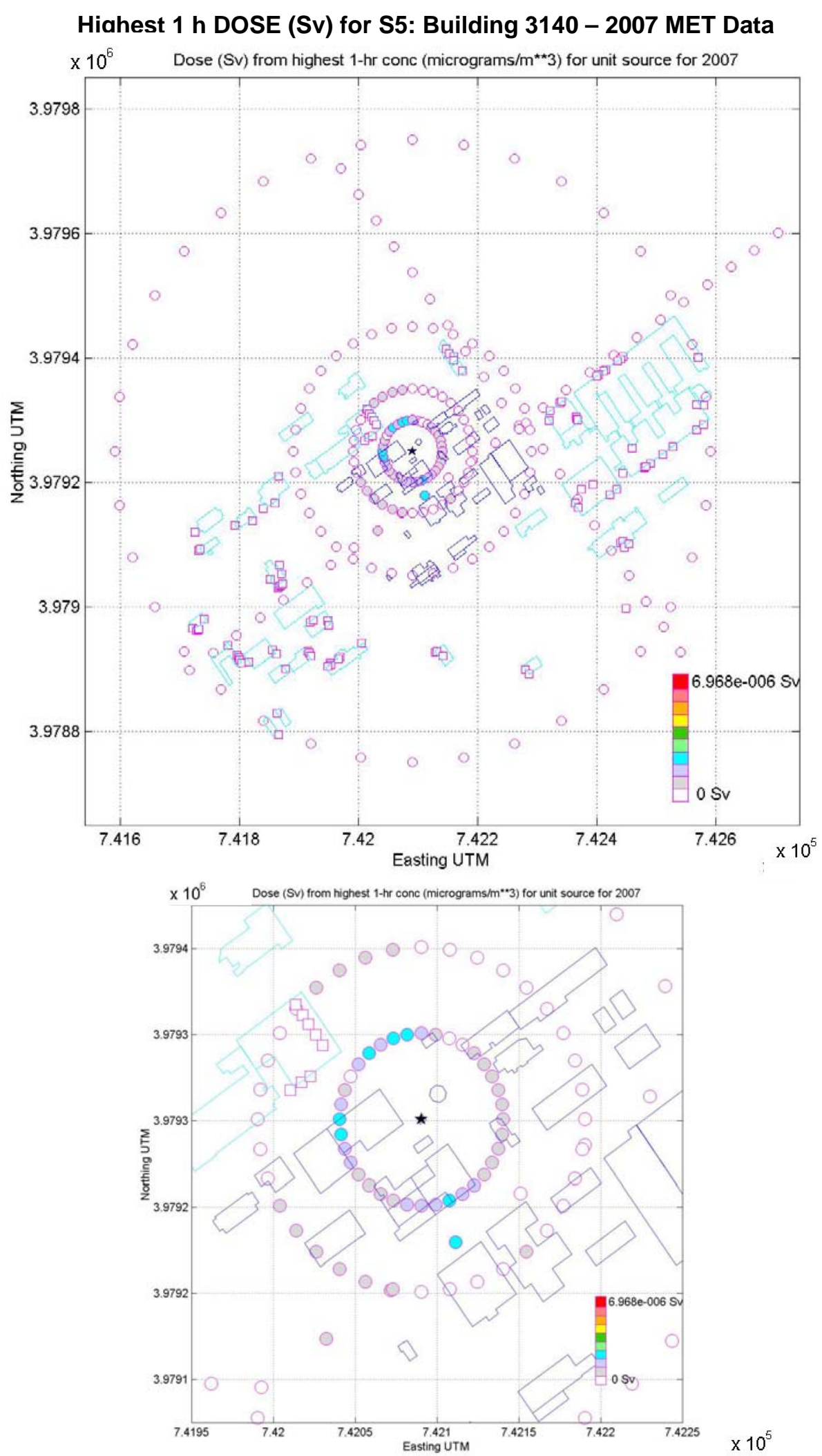

Fig. 12. Effective dose (Sv) for the limiting $1 \mathrm{~h}$ dispersion for S5 and 2007 meteorology. Shown are the entire study area (top) and view close in to source (bottom). 


\subsection{RESULTS FOR 2008 METEOROLOGY 1 H DATA}

\section{Results for S1 (Building 3026D - location is NW Corner at roof level)}

Table 27. Characteristics for S1

\begin{tabular}{|c|c|}
\hline \multicolumn{2}{|c|}{ Source Characteristics } \\
\hline UTM Easting & 742095.5 \\
UTM Northing & 3979226 \\
Elevation & $243.75 \mathrm{~m}$ \\
Height & $14.63 \mathrm{~m}$ \\
QS & $1 \mathrm{~g} / \mathrm{s}$ \\
Temp & $300 \mathrm{~K}$ \\
VS & $0.01 \mathrm{~m} / \mathrm{s}$ \\
DS & $4 \mathrm{~m}$ \\
\hline
\end{tabular}

Table 28. Maximum values for S1 highest $1 \mathrm{~h}$ results for 2008

\begin{tabular}{|c|c|c|}
\hline \multicolumn{3}{|c|}{ Maximum Results } \\
\hline & $\chi / Q\left(\mathrm{~s} / \mathrm{m}^{3}\right)$ & Dose(Sv) \\
\hline AVG & $2.39 \mathrm{E}-4$ & 2.09E-02 \\
\hline $\mathrm{HIGH} 1 \mathrm{HR}$ & $6.74 \mathrm{E}-3$ & 5.88E-01 \\
\hline
\end{tabular}

Summary of results: S1 was located at a high elevation (roof level) in a corner of building 3026D. The high elevation resulted in lower doses that occurred with locations near the ground level. The maximum annual average air dispersion coefficient was $2.39 \mathrm{E}-4 \mathrm{~s} / \mathrm{m}^{3}$. Using the entire building inventory as if it were released in this location, the dose was computed to be $2.09 \mathrm{E}-02 \mathrm{~Sv}$ or $2.09 \mathrm{rem}$.

The limiting $1 \mathrm{~h}$ dispersion coefficient was $6.74 \mathrm{E}-3 \mathrm{~s} / \mathrm{m}^{3}$, which gave an effective dose of $0.588 \mathrm{~Sv}$ or $58.8 \mathrm{rem}$, given the radionuclide inventory for building $3026 \mathrm{D}$. A release from S1 location in building 3026D would result in a large dose along the sidewalk and to buildings across the street to the south.

Note that doses are calculated assuming a complete release of the building inventory. To estimate the dose for a realistic release one should multiply the doses shown in Table 28 by a factor that represents the fraction of the building's inventory expected to be released. For example, assuming that one percent of the inventory in building 3026D is released, then the highest dose would be $0.588 \mathrm{~Sv} * 0.01$ or $0.588 \mathrm{E}$ rem. 

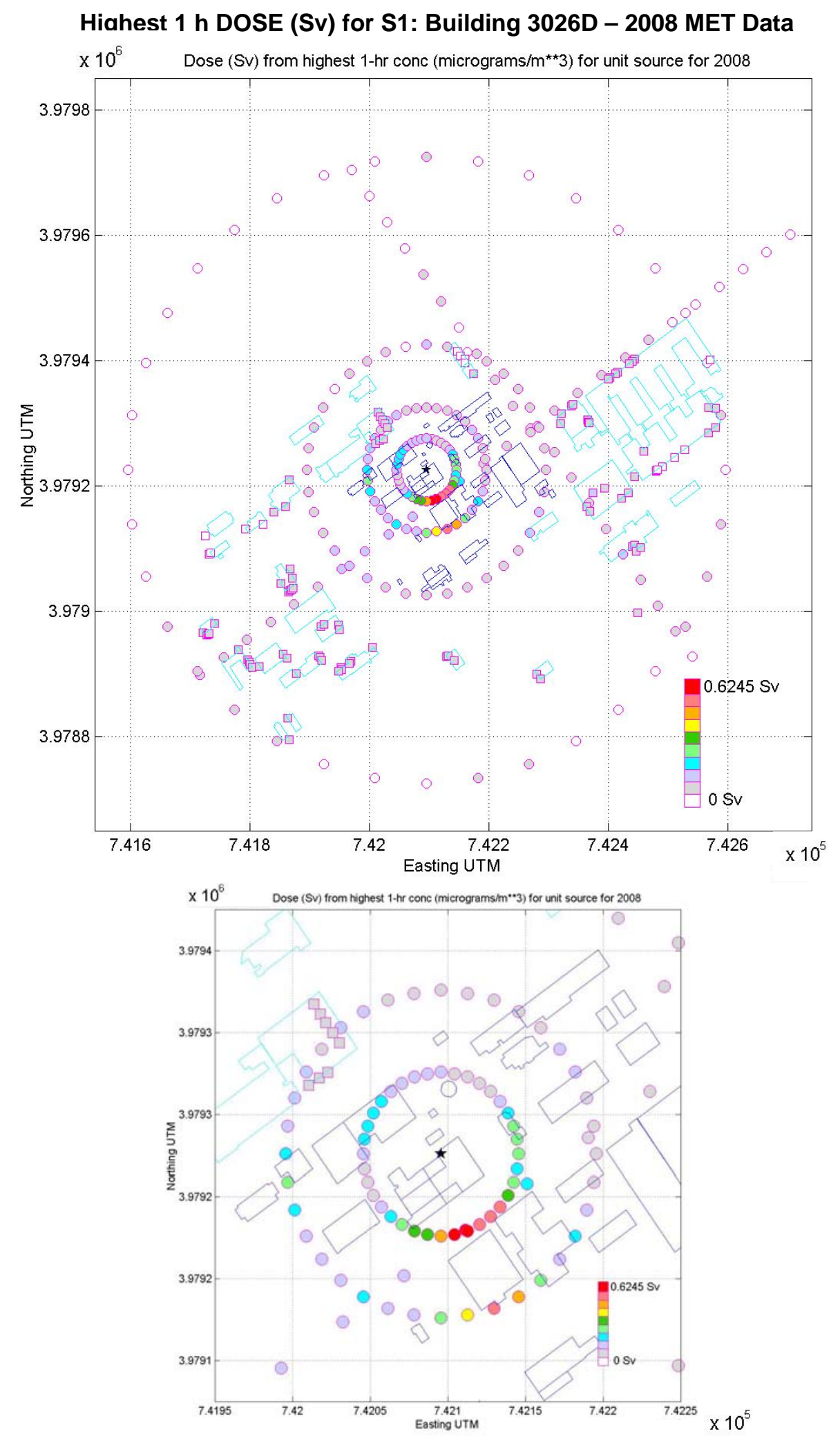

Fig. 13. Effective dose (Sv) for the limiting $1 \mathrm{~h}$ dispersion for S1 and 2008 meteorology. Shown are the entire study area (top) and view close in to source (bottom). 
Results for S2 (Building 3026D - location is center line, left side near ground level)

Table 29. Characteristics for S2

\begin{tabular}{|c|c|}
\hline \multicolumn{2}{|c|}{ Source Characteristics } \\
\hline UTM Easting & 742104 \\
UTM Northing & 3979215 \\
Elevation & 243.4 \\
Height & $1 \mathrm{~m}$ \\
QS & $1 \mathrm{~g} / \mathrm{s}$ \\
Temp & $300 \mathrm{~K}$ \\
VS & $0.01 \mathrm{~m} / \mathrm{s}$ \\
DS & $4 \mathrm{~m}$ \\
\hline
\end{tabular}

Table 30. Maximum values for S2 highest $1 \mathrm{~h}$ results for 2008

\begin{tabular}{|c|c|c|}
\hline \multicolumn{3}{|c|}{ Maximum Results } \\
\hline & $\chi / Q\left(\mathrm{~s} / \mathrm{m}^{3}\right)$ & Dose(Sv) \\
\hline AVG & $7.24 \mathrm{E}-4$ & 6.32E-02 \\
\hline $\mathrm{HIGH} 1 \mathrm{HR}$ & 8.74E-2 & 7.63 \\
\hline
\end{tabular}

Summary of results: S2 was at floor level (1 $\mathrm{m}$ above ground elevation) on the center line, left side of building 3026D. The low elevation and large value of the radionuclide activity in this building resulted in the highest doses of the five sources. The maximum annual average air dispersion coefficient was $7.24 \mathrm{E}-4 \mathrm{~s} / \mathrm{m}^{3}$. Using the entire building inventory as if it were released in this location, the dose was computed to be $6.32 \mathrm{E}-2 \mathrm{~Sv}$ or 6.32 rem.

The limiting $1 \mathrm{~h}$ dispersion coefficient was $8.74 \mathrm{E}-2 \mathrm{~s} / \mathrm{m}^{3}$, which gave an effective dose of $7.63 \mathrm{~Sv}$ or $763 \mathrm{rem}$, given the radionuclide inventory for building 3026D. Compared with $\mathrm{S} 1$, a release from S2 location in building 3026D would result in a significantly larger dose along the sidewalk and to buildings across the street to the south.

Note that doses are calculated assuming a complete release of the building inventory. To estimate the dose for a realistic release one should multiply the doses shown in Table 30 by a factor that represents the fraction of the building's inventory expected to be released. For example, assuming that one percent of the inventory in building 3026D is released, then the highest dose would be $7.63 \mathrm{~Sv} * 0.01$ or $7.63 \mathrm{rem}$. 
Hiahest 1 h DOSE (Sv) for S2: Building 3026D - 2008 MET Data
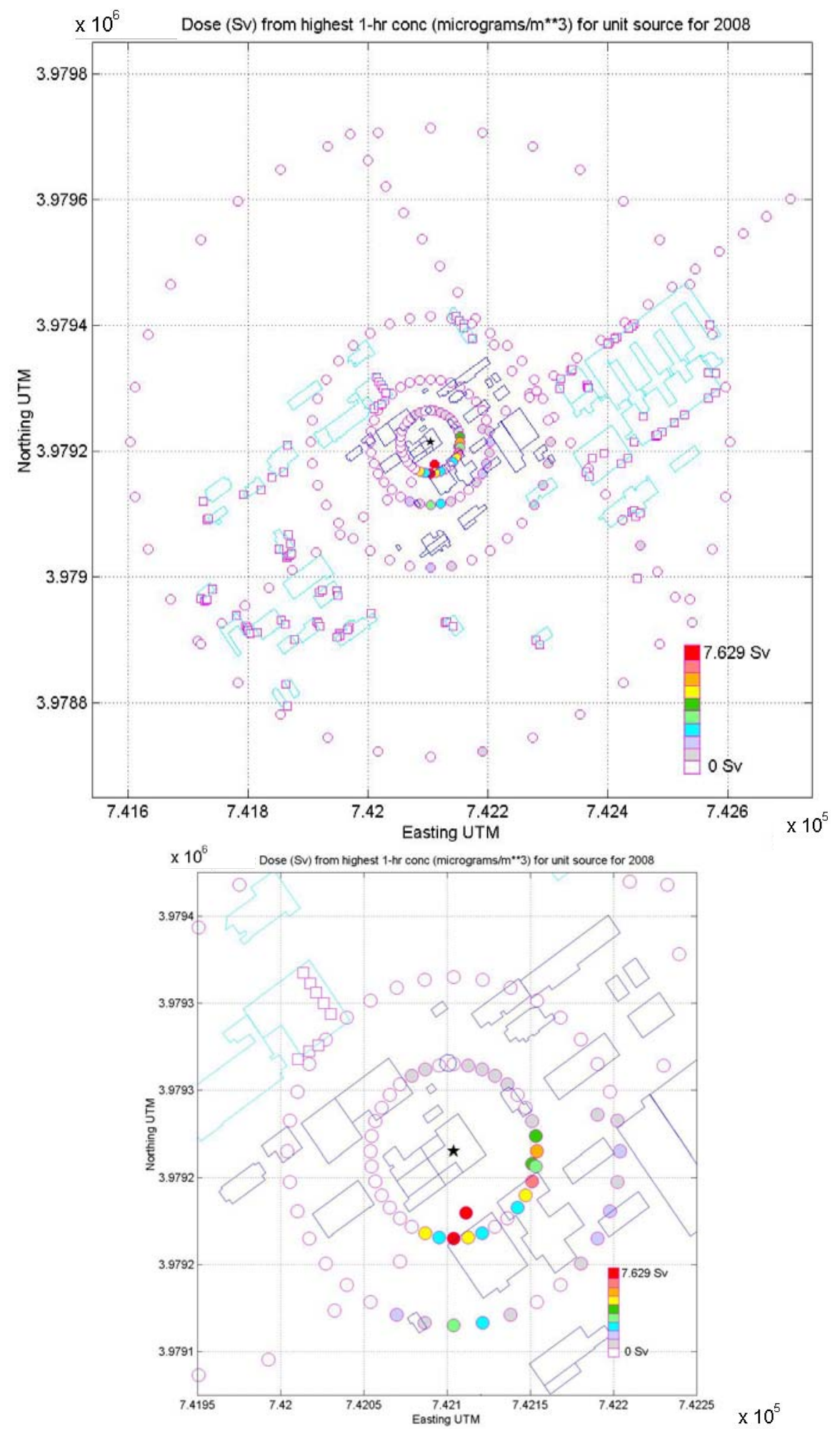

Fig. 14. Effective dose (Sv) for the limiting $1 \mathrm{~h}$ dispersion for S2 and 2006 meteorology. Shown are the entire study area (top) and view close in to source (bottom). 
Results for S3 (Building 3026D - location is center line, above maintenance cubicle roof)

Table 31. Characteristics for S3

\begin{tabular}{|c|c|}
\hline \multicolumn{2}{|c|}{ Source Characteristics } \\
\hline UTM Easting & 742111 \\
UTM Northing & 3979221 \\
Elevation & $243.41 \mathrm{~m}$ \\
Height & $12 \mathrm{~m}$ \\
QS & $1 \mathrm{~g} / \mathrm{s}$ \\
Temp & $300 \mathrm{~K}$ \\
VS & $0.01 \mathrm{~m} / \mathrm{s}$ \\
DS & $4 \mathrm{~m}$ \\
\hline
\end{tabular}

Table 32. Maximum values for S3 highest $1 \mathrm{~h}$ results for 2008

\begin{tabular}{|c|c|c|}
\hline \multicolumn{3}{|c|}{ Maximum Results } \\
\hline & $\chi / Q\left(\mathrm{~s} / \mathrm{m}^{3}\right.$ & Dose(Sv) \\
\hline AVG & $6.75 \mathrm{E}-4$ & $5.89 \mathrm{E}-02$ \\
\hline $\mathrm{HIGH} 1 \mathrm{HR}$ & $2.13 \mathrm{E}-2$ & 1.86 \\
\hline
\end{tabular}

Summary of results: S3 center line above the maintenance roof in building 3026D. The higher elevation of S3 combined with the large value of the radionuclide activity in this building resulted in the higher dose of the first source. The maximum annual average dispersion coefficient was $6.75 \mathrm{E}-4 \mathrm{~s} / \mathrm{m}^{3}$. Using the entire building inventory as if it were released in this location, the dose was computed to be 5.89E-02 Sv or 5.89 rem.

The limiting $1 \mathrm{~h}$ dispersion coefficient was $2.13 \mathrm{E}-2 \mathrm{~s} / \mathrm{m}^{3}$, which gave an effective dose of $1.86 \mathrm{~Sv}$ or $186 \mathrm{rem}$, given the radionuclide inventory for building 3026D.

Note that doses are calculated assuming a complete release of the building inventory. To estimate the dose for a realistic release one should multiply the doses shown in Table 32 by a factor that represents the fraction of the building's inventory expected to be released. For example, assuming that one percent of the inventory in building $3026 \mathrm{D}$ is released, then the highest dose would be $1.86 \mathrm{~Sv} * 0.01$ or $1.86 \mathrm{rem}$. 


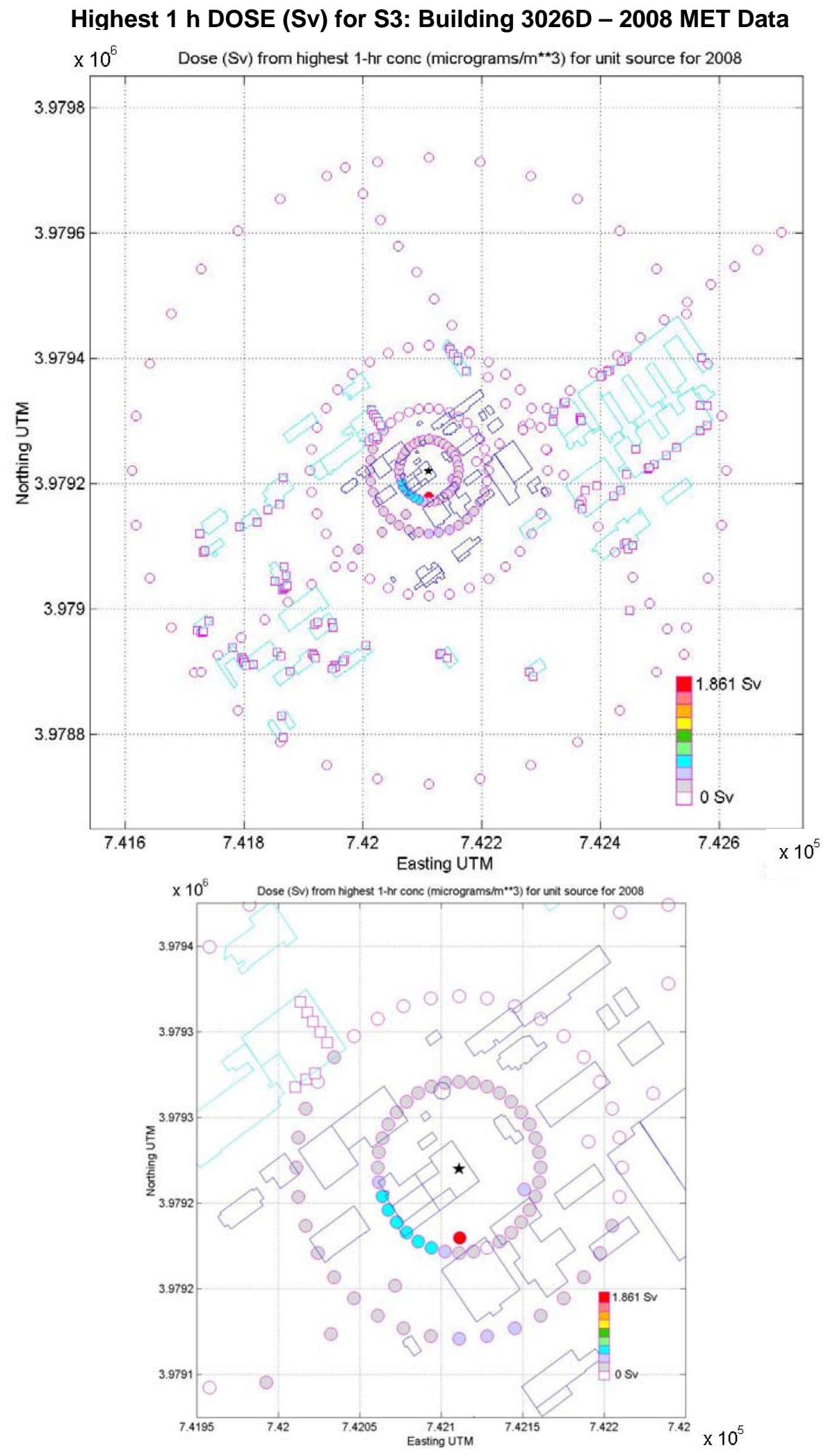

Fig. 15. Effective dose (Sv) for the limiting $1 \mathrm{~h}$ dispersion for S3 and 2008 meteorology. Shown are the entire study area (top) and view close in to source (bottom). 


\section{Results for S4 (Building 3026C - location is NW side near ground level)}

Table 33. Characteristics for S4

\begin{tabular}{|c|c|}
\hline \multicolumn{2}{|c|}{ Source Characteristics } \\
\hline UTM Easting & 742080 \\
UTM Northing & 3979209 \\
Elevation & 243.49 \\
Height & $1 \mathrm{~m}$ \\
QS & $1 \mathrm{~g} / \mathrm{s}$ \\
Temp & $300 \mathrm{~K}$ \\
VS & $0.01 \mathrm{~m} / \mathrm{s}$ \\
DS & $4 \mathrm{~m}$ \\
\hline
\end{tabular}

Table 34. Maximum values for S4 highest $1 \mathrm{~h}$ results for 2008

\begin{tabular}{|ccc|}
\hline \multicolumn{3}{|c|}{ Maximum Results } \\
\hline & $\chi / \mathrm{Q}\left(\mathrm{s} / \mathrm{m}^{3}\right)$ & Dose(Sv) \\
AVG & $9.10 \mathrm{E}-4$ & $1.24 \mathrm{E}-04$ \\
HIGH 1HR & $7.85 \mathrm{E}-2$ & $1.07 \mathrm{E}-02$ \\
\hline
\end{tabular}

Summary of results: S4 is located on the NW side building 3026C at floor level $(1 \mathrm{~m}$ above ground elevation). The low elevation resulted in high air concentrations, but the relatively small value of the radionuclide activity in this building resulted in the second lowest doses of the five sources. The maximum annual average air dispersion coefficient was $9.10 \mathrm{E}-4 \mathrm{~s} / \mathrm{m}^{3}$. Using the entire building inventory as if it were released in this location, the dose was computed to be $1.24 \mathrm{E}-4 \mathrm{~Sv}$ or $0.0124 \mathrm{rem}$.

The limiting $1 \mathrm{~h}$ dispersion coefficient was $7.85 \mathrm{E}-2 \mathrm{~s} / \mathrm{m}^{3}$, which gave an effective dose of 1.07E-02 Sv or $1.07 \mathrm{rem}$, given the radionuclide inventory for building 3026C. While the dispersion coefficients are high, the inventory in building 3026C results in very low doses.

Note that doses are calculated assuming a complete release of the building inventory. To estimate the dose for a realistic release one should multiply the doses shown in Table 34 by a factor that represents the fraction of the building's inventory expected to be released. For example, assuming that one percent of the inventory in building $3026 \mathrm{C}$ is released, then the highest dose would be $1.07 \mathrm{E}-02 \mathrm{~Sv} * 0.01$ or $1.07 \mathrm{E}-02$ rem. 
Highest 1 h DOSE (Sv) for S4: Building 3026C - 2008 MET Data
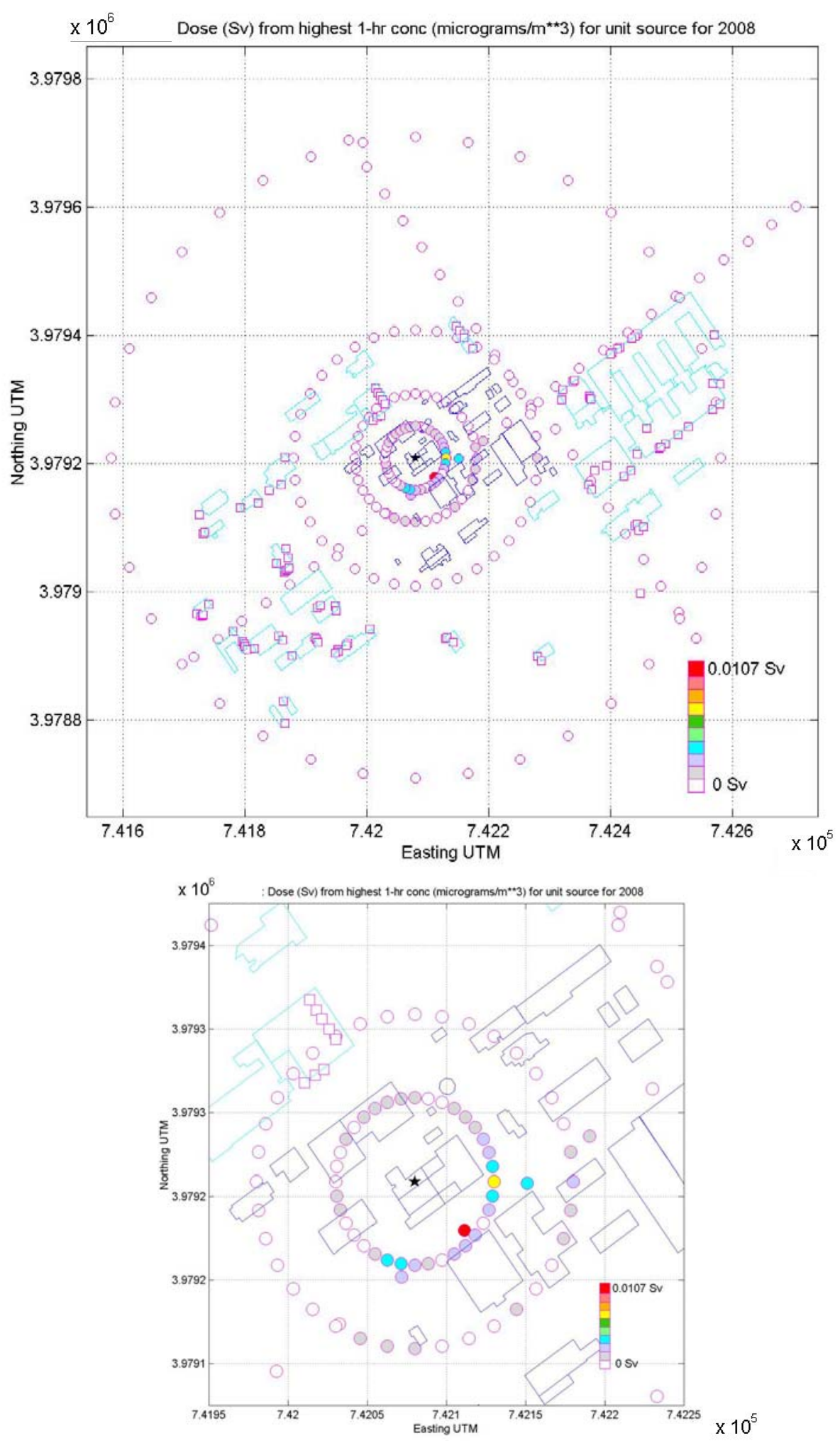

Fig. 16. Effective dose (Sv) for the limiting $1 \mathrm{~h}$ dispersion for S4 and 2008 meteorology. Shown are the entire study area (top) and view close in to source (bottom). 


\section{Results for S5 (Building 3140 - location is center of building near ground level)}

Table 35. Characteristics for S5

\begin{tabular}{|c|c|}
\hline \multicolumn{2}{|c|}{ Source Characteristics } \\
\hline UTM Easting & 742090.5 \\
UTM Northing & 3979250.8 \\
Elevation & $244.69 \mathrm{~m}$ \\
Height & $1 \mathrm{~m}$ \\
QS & $1 \mathrm{~g} / \mathrm{s}$ \\
Temp & $300 \mathrm{~K}$ \\
VS & $0.01 \mathrm{~m} / \mathrm{s}$ \\
DS & $4 \mathrm{~m}$ \\
\hline
\end{tabular}

Table 36. Maximum values for S5 highest $1 \mathrm{~h}$ results for 2008

\begin{tabular}{|ccc|}
\hline \multicolumn{3}{|c|}{ Maximum Results } \\
\hline & $\chi / Q\left(\mathrm{~s} / \mathrm{m}^{3}\right)$ & Dose(Sv) \\
AVG & $7.16 \mathrm{E}-4$ & $8.42 \mathrm{E}-08$ \\
HIGH 1HR & $5.92 \mathrm{E}-2$ & $6.97 \mathrm{E}-06$ \\
\hline
\end{tabular}

Summary of results: S5 is located in the center of filter house 3140 at floor level ( $1 \mathrm{~m}$ above ground elevation). The low elevation and small value of the radionuclide activity in this building resulted in the lowest doses of the five sources. The maximum annual average air dispersion coefficient was $7.16 \mathrm{E}-4 \mathrm{~s} / \mathrm{m}^{3}$. Using the entire building inventory as if it were released in this location, the dose was computed to be $8.42 \mathrm{E}-08 \mathrm{~Sv}$ or $8.42 \mathrm{E}-6 \mathrm{rem}$.

The limiting $1 \mathrm{~h}$ dispersion coefficient was $5.92 \mathrm{E}-2 \mathrm{~s} / \mathrm{m}^{3}$, which gave an effective dose of 6.97E-06 Sv or 6.97E-04 rem, given the radionuclide inventory for filter house 3140 . The combination of low dispersion coefficients and the inventory in the filter house 3140 results in extremely low doses.

Note that doses are calculated assuming a complete release of the building inventory. To estimate the dose for a realistic release one should multiply the doses shown in Table 36 by a factor that represents the fraction of the building's inventory expected to be released. For example, assuming that fifty percent of the inventory in filter house 3140 is released, then the highest dose would be $6.97 \mathrm{E}-06 \mathrm{~Sv} * 0.5$ or $3.49 \mathrm{E}-04$ rem. 

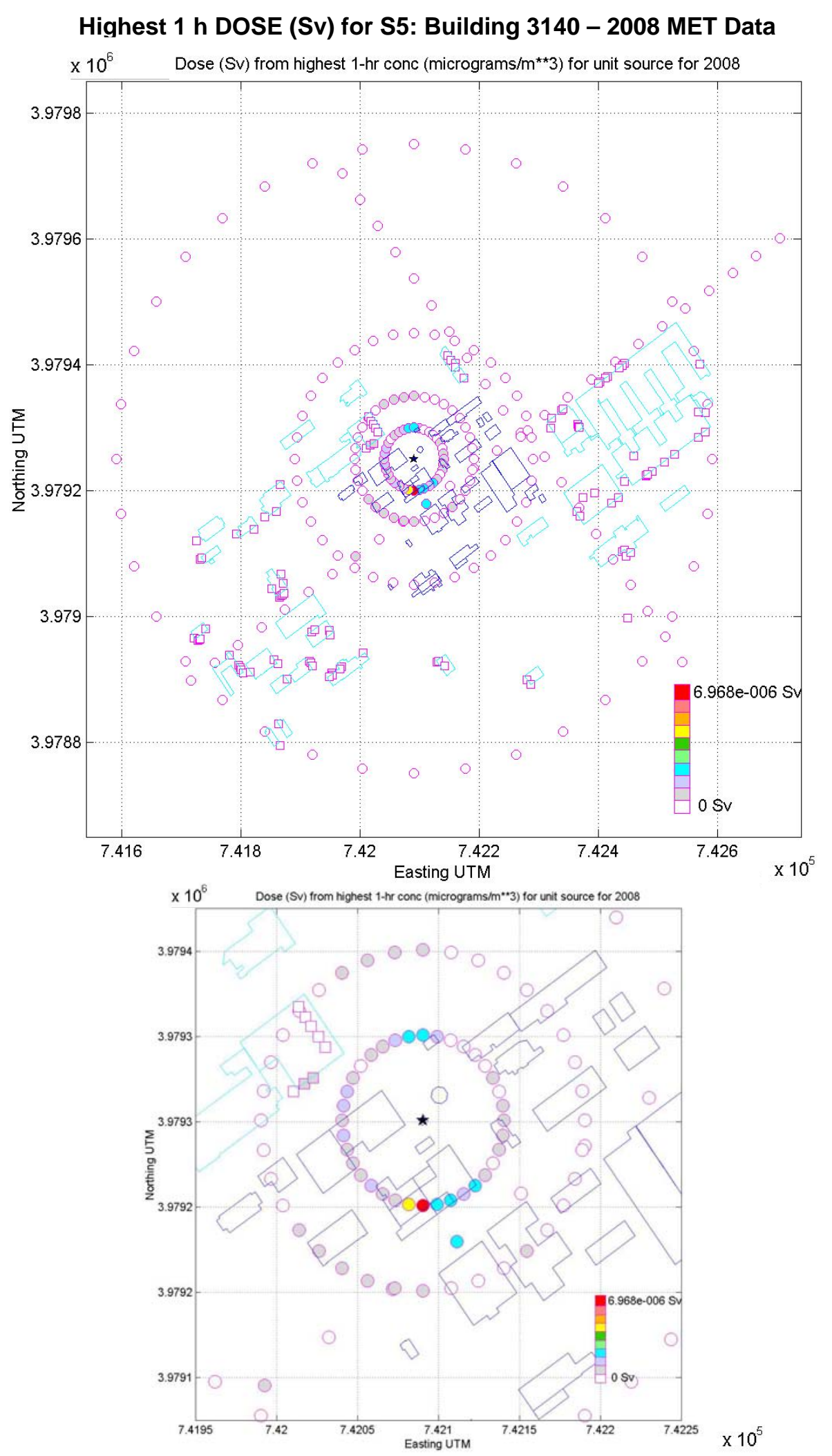

Fig. 17. Effective dose (Sv) for the limiting $1 \mathrm{~h}$ dispersion for S5 and 2008 meteorology. Shown are the entire study area (top) and view close in to source (bottom). 


\section{CONCLUSIONS}

The EPA AERMOD system was used to estimate air dispersion coefficients and effective dose resulting from a release of a pollutant from ORNL buildings $3026 \mathrm{C}, 3026 \mathrm{D}$, and filter house 3140 , for potential air dispersion scenarios resulting from an uncontrolled release prior to or during the demolition of the 3026 complex. Five source locations (three in 3026D and one each in 3036C and 3140) and associated source characteristics in the area of study were determined with the customer. Once the area of study was determined, building footprints and intake locations of air-handling systems were obtained. In addition to air intakes, receptor locations included concentric polar grids centered on the source location ( $50 \mathrm{~m}, 100 \mathrm{~m}, 200 \mathrm{~m}$, and $500 \mathrm{~m})$, and two intersecting sidewalks corresponding to Central Avenue and Fifth Street.

The AERMET code was used to compute the meteorological input required by AERMOD. Three years of meteorological data (2006-2008) were used including: National Weather Service data and upper air data for the Knoxville-Oak Ridge area along with local weather data from Tower C (10 m, $30 \mathrm{~m}$, and $100 \mathrm{~m})$ on the ORNL reservation.

Annual average air concentration, highest $1 \mathrm{~h}$ average and highest $3 \mathrm{~h}$ average air concentrations were computed using AERMOD for the five source locations for the three years of meteorological data. Since the customer was interested in the most significant response and the highest $1 \mathrm{~h}$ average data reflects the finest time averaged values available from the AERMOD code, we chose to concentrate this analysis on the those results. Dispersion coefficients $\left(\mathrm{s} / \mathrm{m}^{3}\right)$ were computed from the $1 \mathrm{~h}$ average air concentration data. A code was written to take the radionuclide inventories for the buildings (3026D, 3026C and 3140) and convert the limiting $1 \mathrm{~h}$ dispersion coefficients to effective doses $(\mathrm{Sv})$. The resulting doses then reflect the release of the entire inventory for each building since a constant steady-state release of $1 \mathrm{~g} / \mathrm{s}$ was assumed in the AERMOD calculations. Suggestions are provided on how to scale these results when the amount of the inventory released can be estimated.

The source locations showed considerable variation in effective dose (Sv). Of the five locations, sources in building 3026D showed the highest doses. Source S2 near ground level in building 3026D produced the highest doses, due to the release being at ground level and to the particular inventory of that building. Source S3 at the height of the maintenance roof in 3026D showed the second highest doses, reduced from those of S2 due to greater height of the source location. The release at the highest location (S1 at the roof level) produced the lowest values for 3026D, but values above those of the other locations (3026C and 3140). Dispersion coefficients from the ground level release from building $3026 \mathrm{C}$ were high, but the resulting effective doses were low due to the inventory in the building provided by the Preliminary Hazard Screening report. ${ }^{7}$ Finally, the release from the filter house 3140 produced the lowest effective doses due to the inventory in that location. 
In general the pattern of release showed higher doses toward the prevailing wind directions (along the valley), which also are parallel to the sidewalk along Central Avenue. In addition, doses were generally higher to the south of the complex of buildings due to building downwash effects and the presence of the hillside to the north. Thus, while care must be taken with all areas near the $3026 \mathrm{D} / \mathrm{C}$ complex, special care should be exercised to prevent exposure along the sidewalk in front of the 3026 complex and in occupied buildings that are across the street, south of the complex.

\section{REFERENCES}

1. Source for the AERMOD code and documentation is this EPA web site: http://www.epa.gov/scram001/dispersion_prefrec.htm; Technology Transfer Network Support Center for Regulatory Atmospheric Modeling, Last updated on Friday, May 29th, 2009.

2. AERMOD Documentation:

User's Guide for the AMS/EPA Regulatory Model - AERMOD, EPA-454/B-03-001, U. S. Environmental Protection Agency, Research Triangle Park, North Carolina, September 2004.

3. AERMAP Documentation:

User's Guide for the AERMOD Terrain Preprocessor (AERMAP), EPA-454/B03-003, U. S. Environmental Protection Agency, Research Triangle Park, North Carolina.

October 2004.

4. AERMET Documentation:

User's Guide for the AERMOD Meteorological Preprocessor (AERMET), EPA-454/B03-002, U. S. Environmental Protection Agency, Research Triangle Park, North Carolina. November 2004.

5. AERSURFACE Documentation:

AERSURFACE User's Guide, EPA-454/B-08-001, U. S. Environmental Protection Agency, Research Triangle Park, North Carolina. January 2008.

6. BPIPPRIME Documentation:

L.L. Schulman, D. G. Strimaitis. J.S. Scire, Addendum to ISC3 User's Guide:The Prime Plume Rise and Building Downwash Model, prepared for Electric Power Research Institute by Earth Tech, Inc. November 1997.

7. Preliminary Hazard Screening for Buildings 3026C, 3026D, and Filter House 3140. PHS-OR-3026-0997 Rev 0. 

APPENDIX A. DETAILS OF THE AERMOD PROCEDURE 


\section{APPENDIX A. DETAILS OF THE AERMOD PROCEDURE.}

The sequence of operation of the AERMOD suite of codes is diagramed below (Fig. A1).

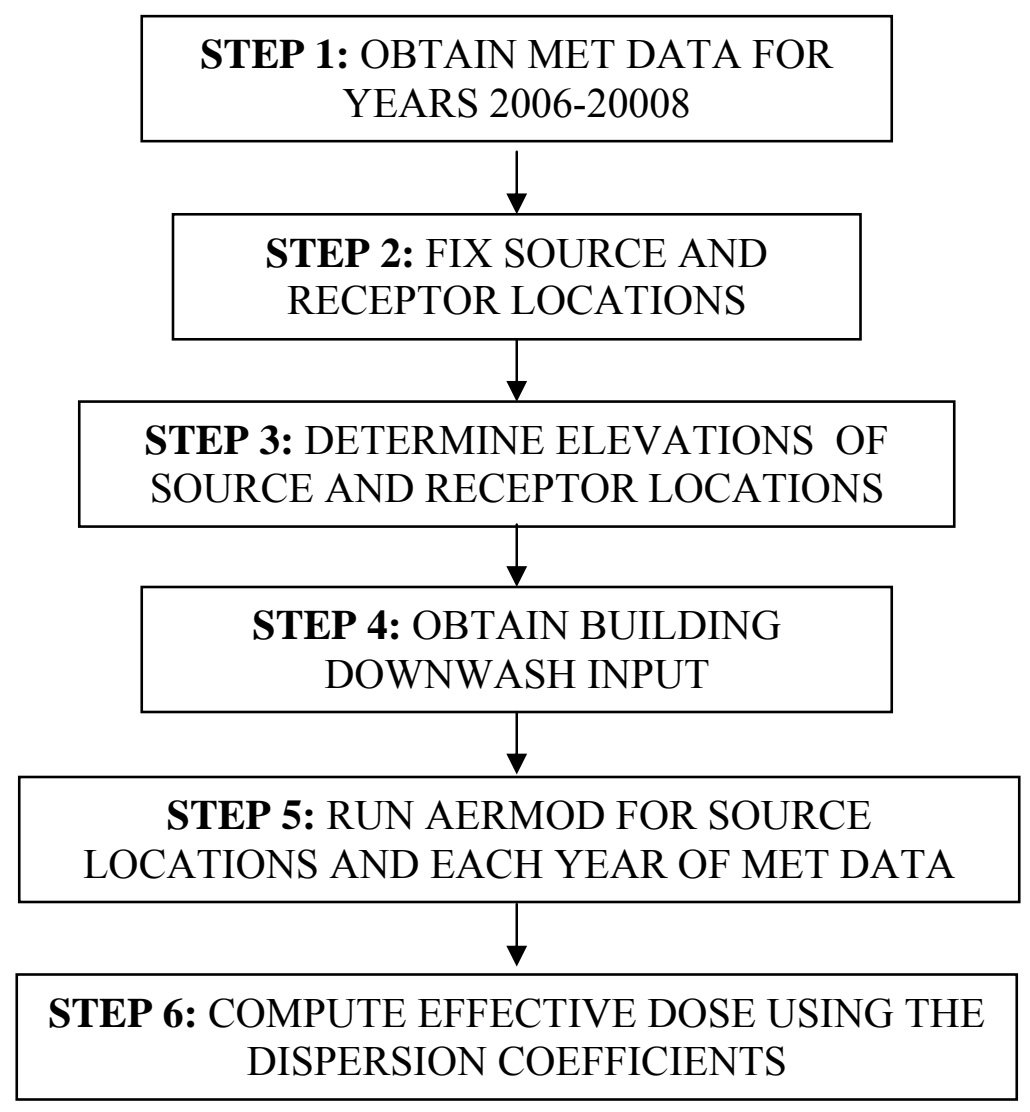

Fig. A1. Diagram of the AERMOD computational process.

1) The requisite meteorological (MET) data for one year (2006) was obtained; upper air, surface and location MET data were converted into the AERMOD formats. Once that was successful, the process was repeated using the 2007 and 2008 MET data. Wind roses for those three years are shown in Appendix B.

2) Locations for source and receptors were determined. Three types of receptors were defined: sidewalks, polar grid locations, and locations of building air intakes. Each of these receptor groups were run separately in AERMOD. The sidewalks consisted of fixed linear tracts (sidewalks) that bisect the site roughly corresponding to sidewalks along the south side of Central Avenue (roughly a SW-NE direction) and along Fifth Street (roughly a NW-SE direction). In addition, receptors were defined on four polar grids centered on the source. The polar grids had radii of $50 \mathrm{~m}, 100 \mathrm{~m}, 200 \mathrm{~m}$, and $500 \mathrm{~m}$ and receptors were placed at $10^{\circ}$ intervals starting at $10^{\circ}$ from north and processing clockwise. Finally, we identified a number of the air intake locations on buildings (mostly outside the $200 \mathrm{~m}$ polar ring), to predict concentrations that might enter buildings. Coordinates for these air intake positions had to be in UTM format. 
3) AERMAP, which references a topographic map of the region, was used to obtain the elevations of the source and receptors. The elevation of the air intakes were estimated or obtained from facilities managers. The elevations of the linear and polar grids were taken as ground level.

4) Once the source locations were decided upon, BPIPPRIME was used to determine the effects of downwash due to a group of buildings within about 200 meters of buildings $3026 \mathrm{C}$ and 3026D. This downwash result, which varies for each of the source locations, is included in AERMOD for computations for each of the source locations.

5) AERMOD was run for each of a total of five source terms and the following results extracted: a) the average air concentrations (averaged of all hours of the one year period), b) the $1^{\text {st }}$ highest $1 \mathrm{~h}$ average concentration, and c) the $1^{\text {st }}$ highest $3 \mathrm{~h}$ average concentration for each of the three years of MET data. In each case the units are $\mu \mathrm{g} / \mathrm{m}^{3}$. Then, these air concentration results were converted to average and limited $1 \mathrm{~h}$ air dispersion coefficients $\left(\mathrm{s} / \mathrm{m}^{3}\right)$. Plots of 1-h average concentration for each source and meteorological dataset were made using MATLAB.

6) DoseCal was used to compute the effective dose ( $\mathrm{Sv}$ ) given the air dispersion coefficients $\left(\mathrm{s} / \mathrm{m}^{3}\right)$ and the inventory for each source location (see Appendix E). DoseCal was written in PowerBasic by Keith Eckerman of the Environmental Sciences Division. The code is based on extensive previous experience in determining inhalation and air immersion doses. Plots of effective dose were made for each source and meteorological dataset were made using MATLAB and are presented in this report. 
APPENDIX B. WIND ROSES FOR 2006-2008 


\section{APPENDIX B. WIND ROSES FOR 2006-2008}

Wind roses for 2006 for the three measurement heights $(10 \mathrm{~m}, 30 \mathrm{~m}$, and $100 \mathrm{~m})$ of Tower C are shown in Figs B1-B3.

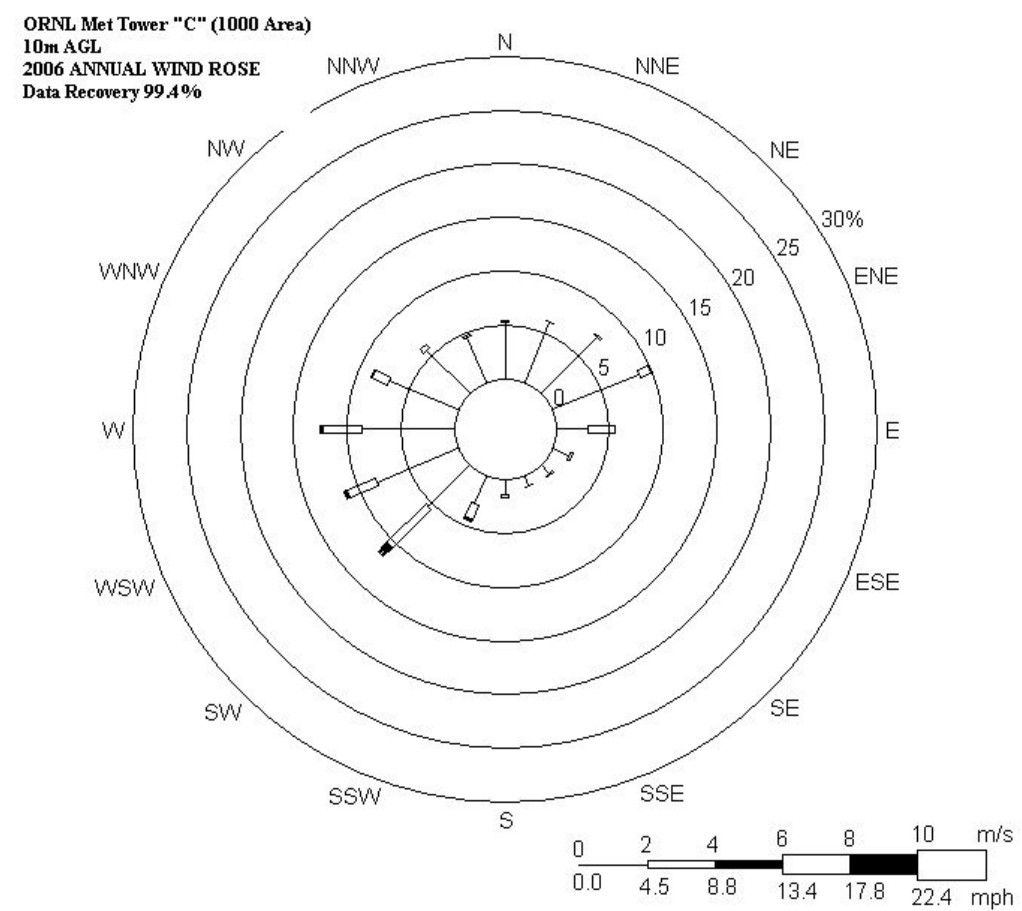

Fig. B1. Wind rose for $10 \mathrm{~m}$ height on Tower C for 2006

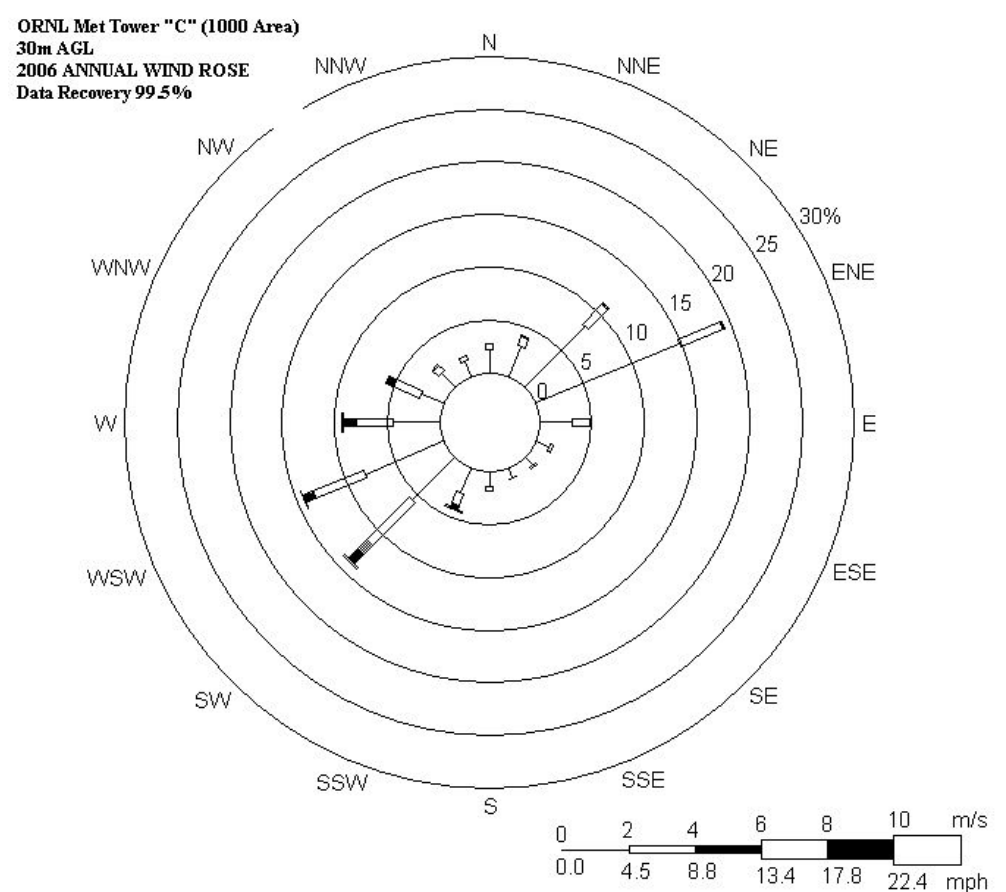

Fig. B2. Wind rose for $30 \mathrm{~m}$ height on Tower C for 2006 


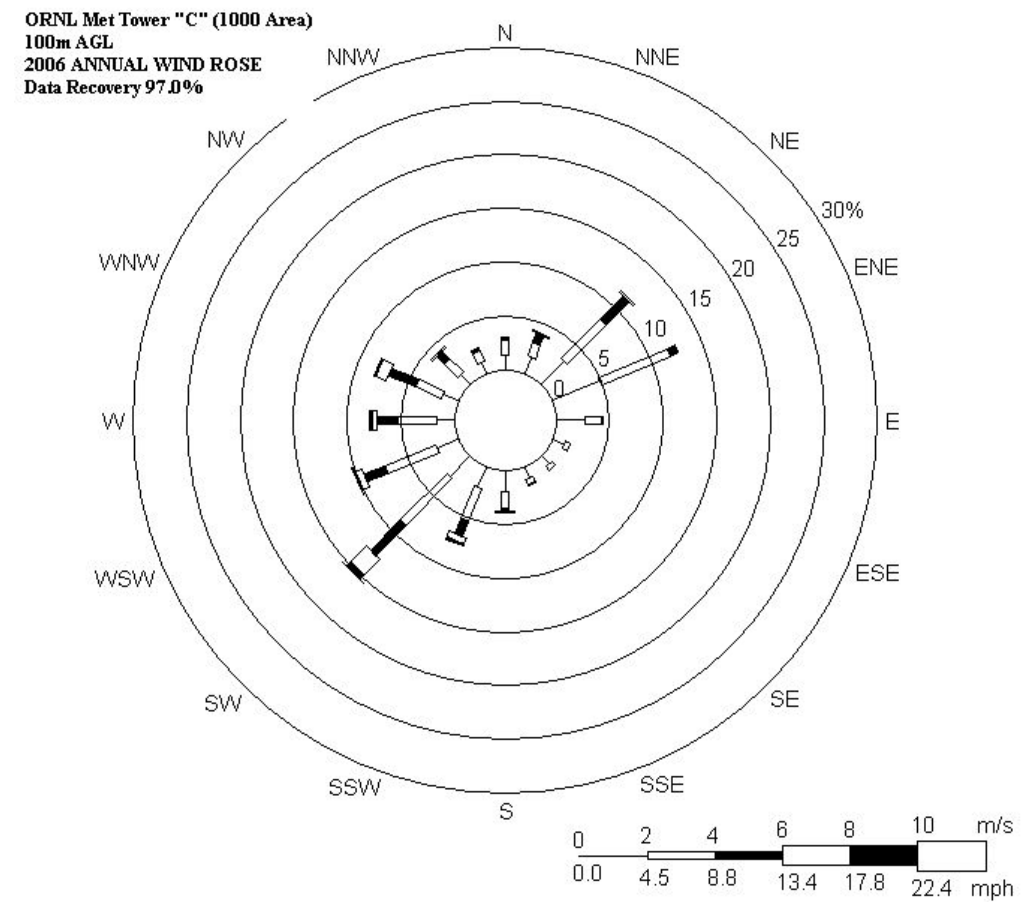

Fig. B3. Wind rose for $100 \mathrm{~m}$ height on Tower C for 2006

Wind roses for 2007 for the three measurement heights $(10 \mathrm{~m}, 30 \mathrm{~m}$, and $100 \mathrm{~m})$ of Tower C are shown in Figs B4-B6.

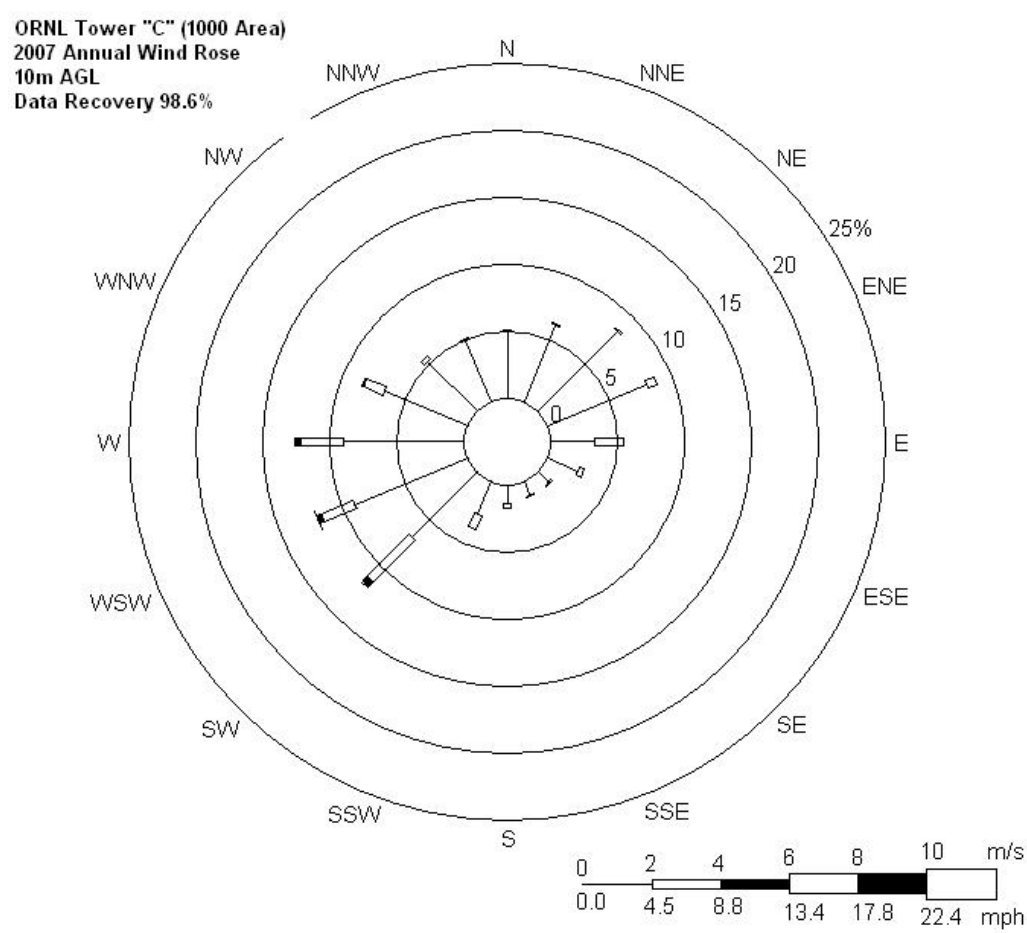

Fig. B4. Wind rose for $10 \mathrm{~m}$ height on Tower C for 2007. 


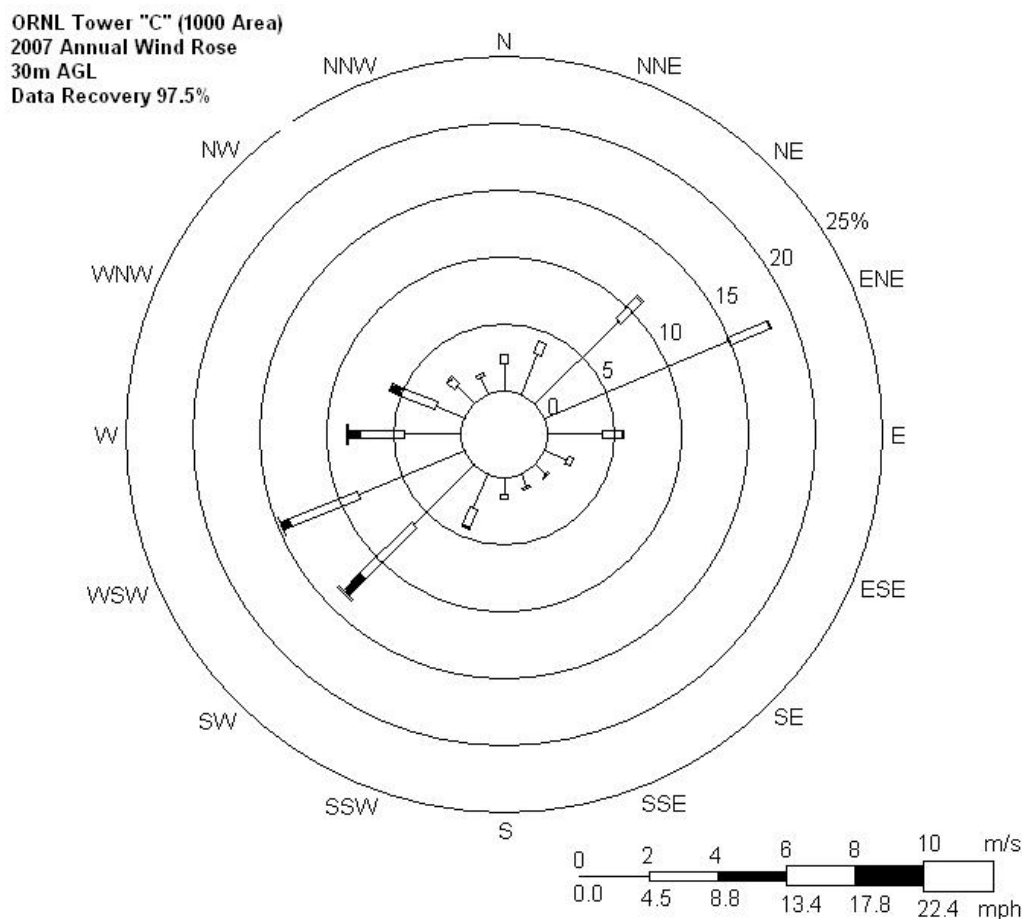

Fig. B5. Wind rose for $30 \mathrm{~m}$ height on Tower C for 2007.

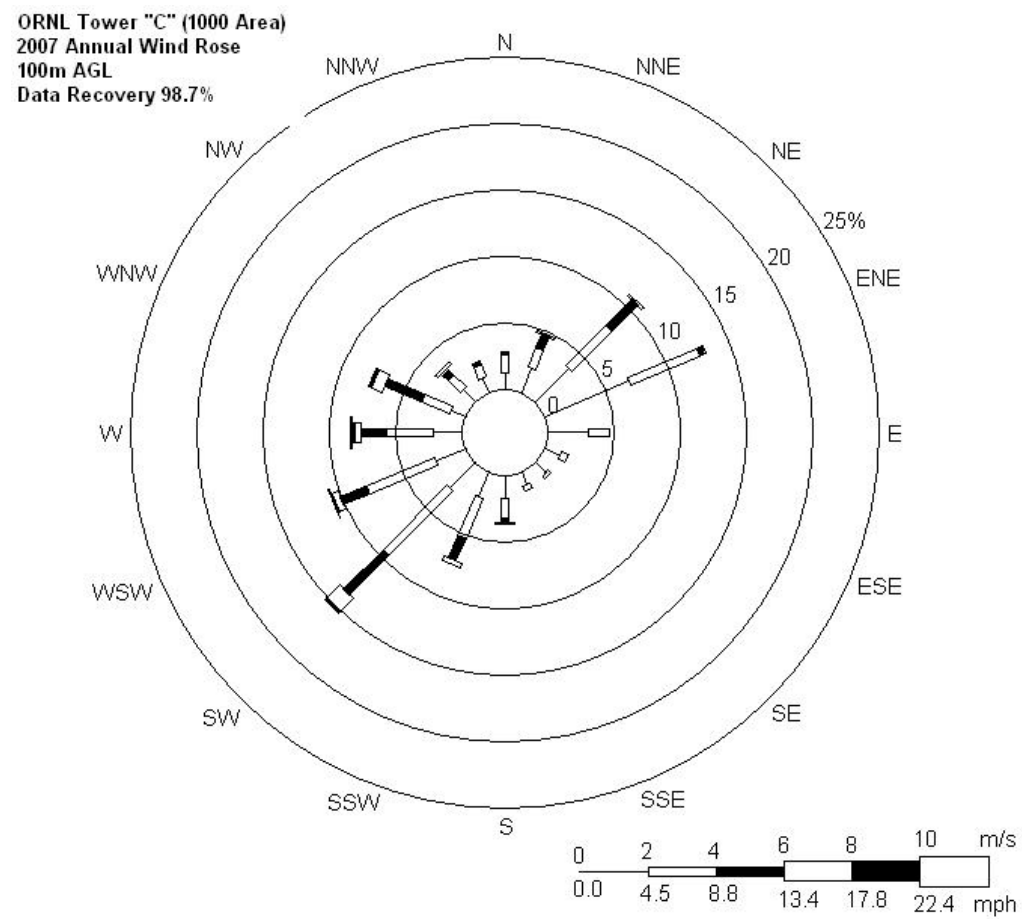

Fig. B6. Wind rose for 100 m height on Tower C for 2007. 
Wind roses for 2008 for the three measurement heights $(10 \mathrm{~m}, 30 \mathrm{~m}$, and $100 \mathrm{~m})$ of Tower C are shown in Figs B7-B9.

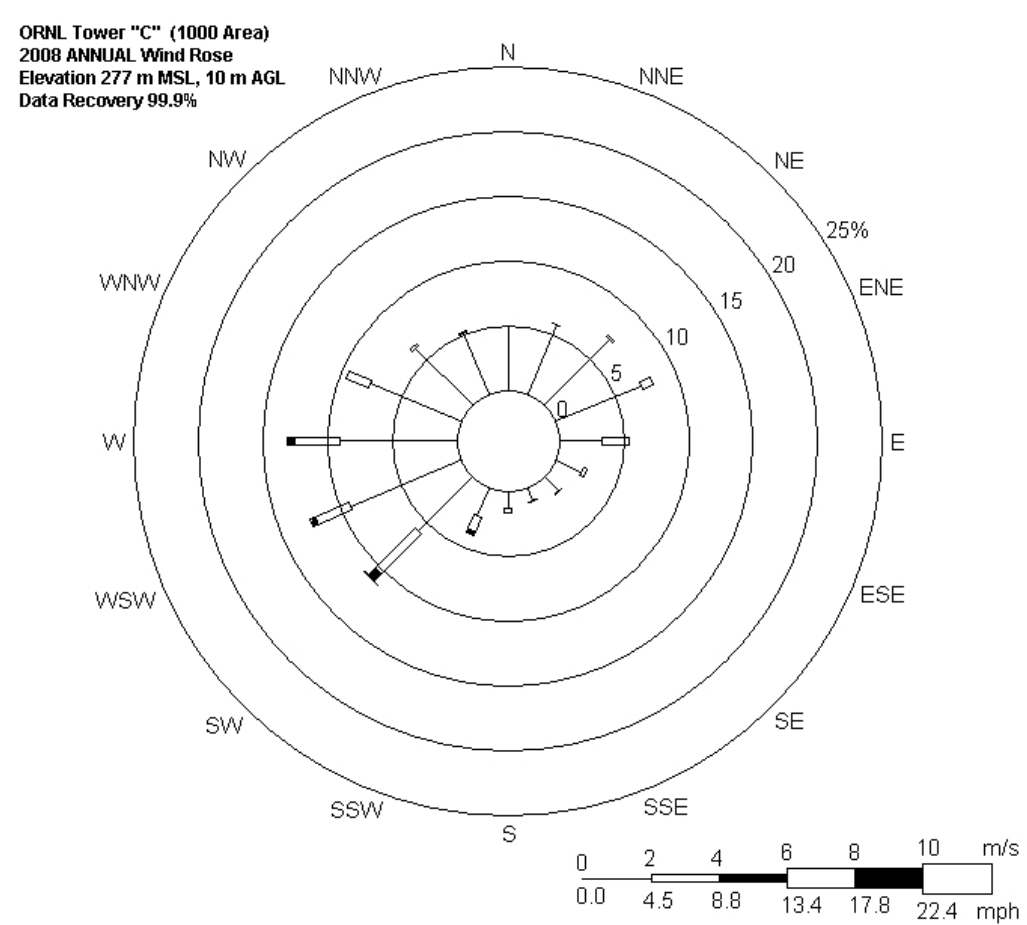

Fig. B7. Wind rose for $10 \mathrm{~m}$ height on Tower C for 2008.

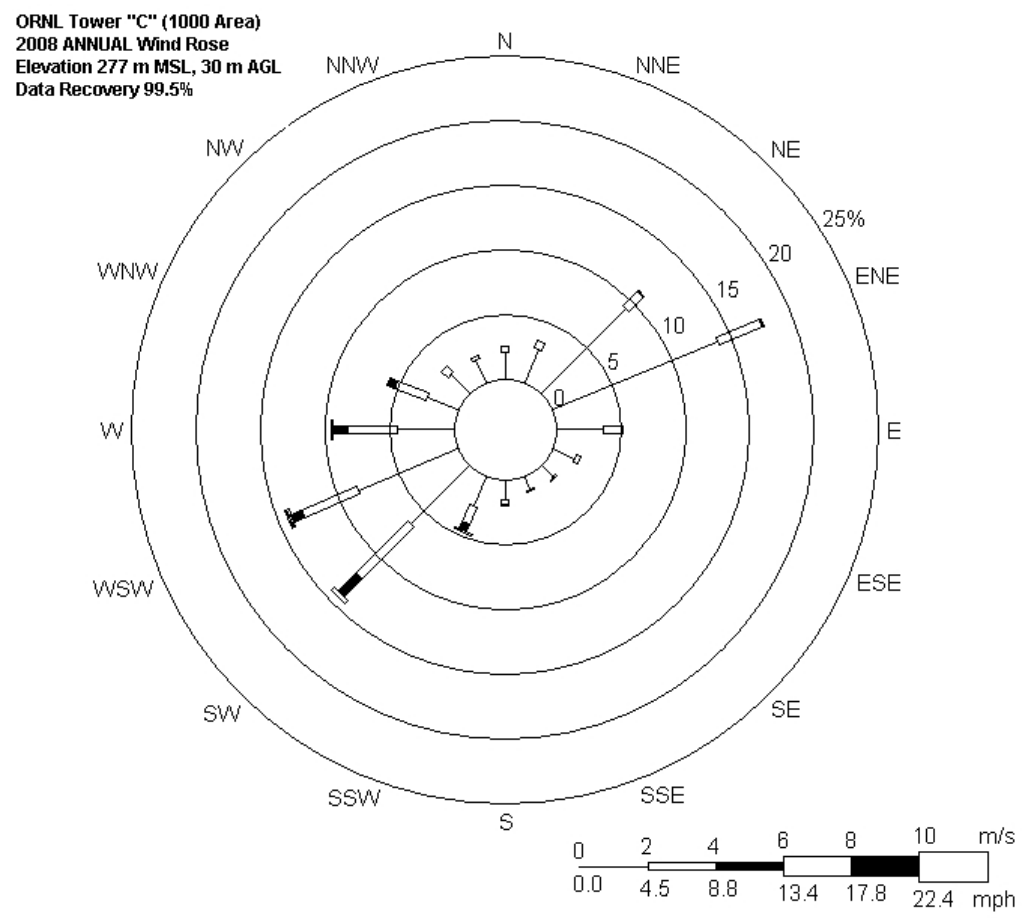

Fig. B8. Wind rose for $30 \mathrm{~m}$ height on Tower C for 2008 . 


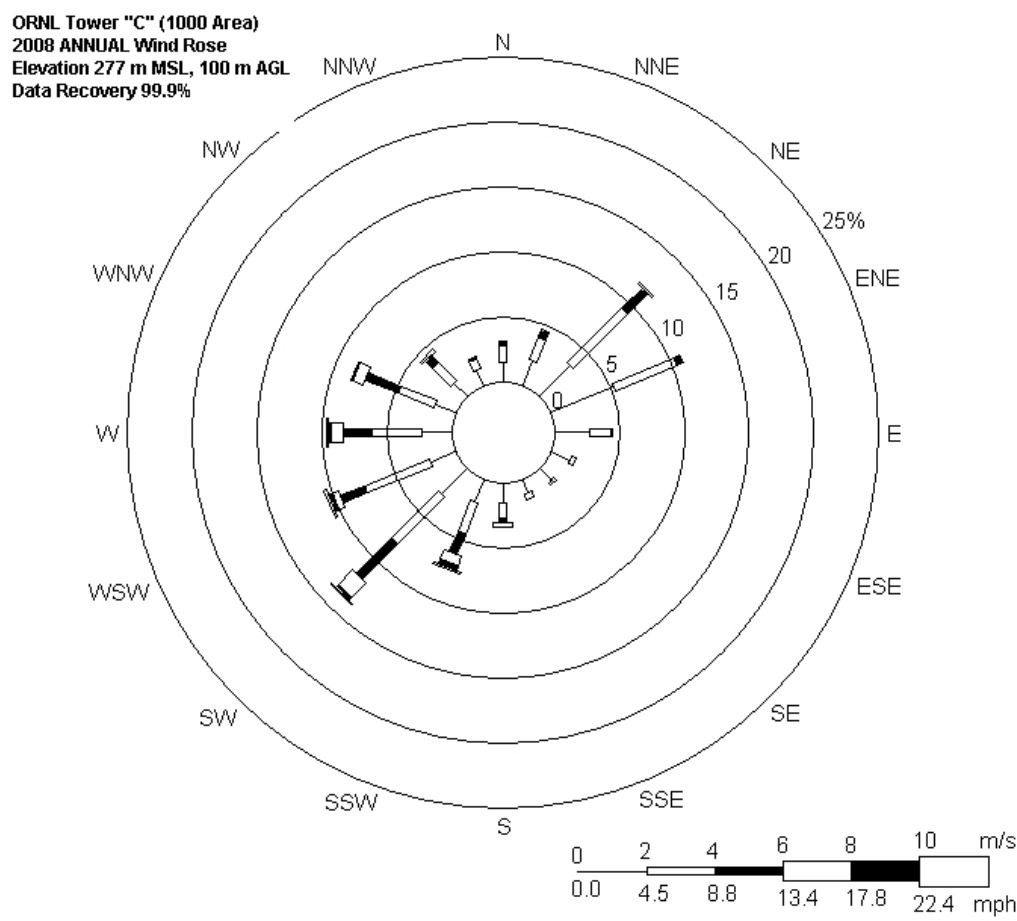

Fig. B9. Wind rose for 100 m height on Tower C for 2008. 
APPENDIX C. BPIPPRIME INPUT / BUILDING DATA 


\section{APPENDIX C: BPIPPRIME INPUT / BUILDING DATA}

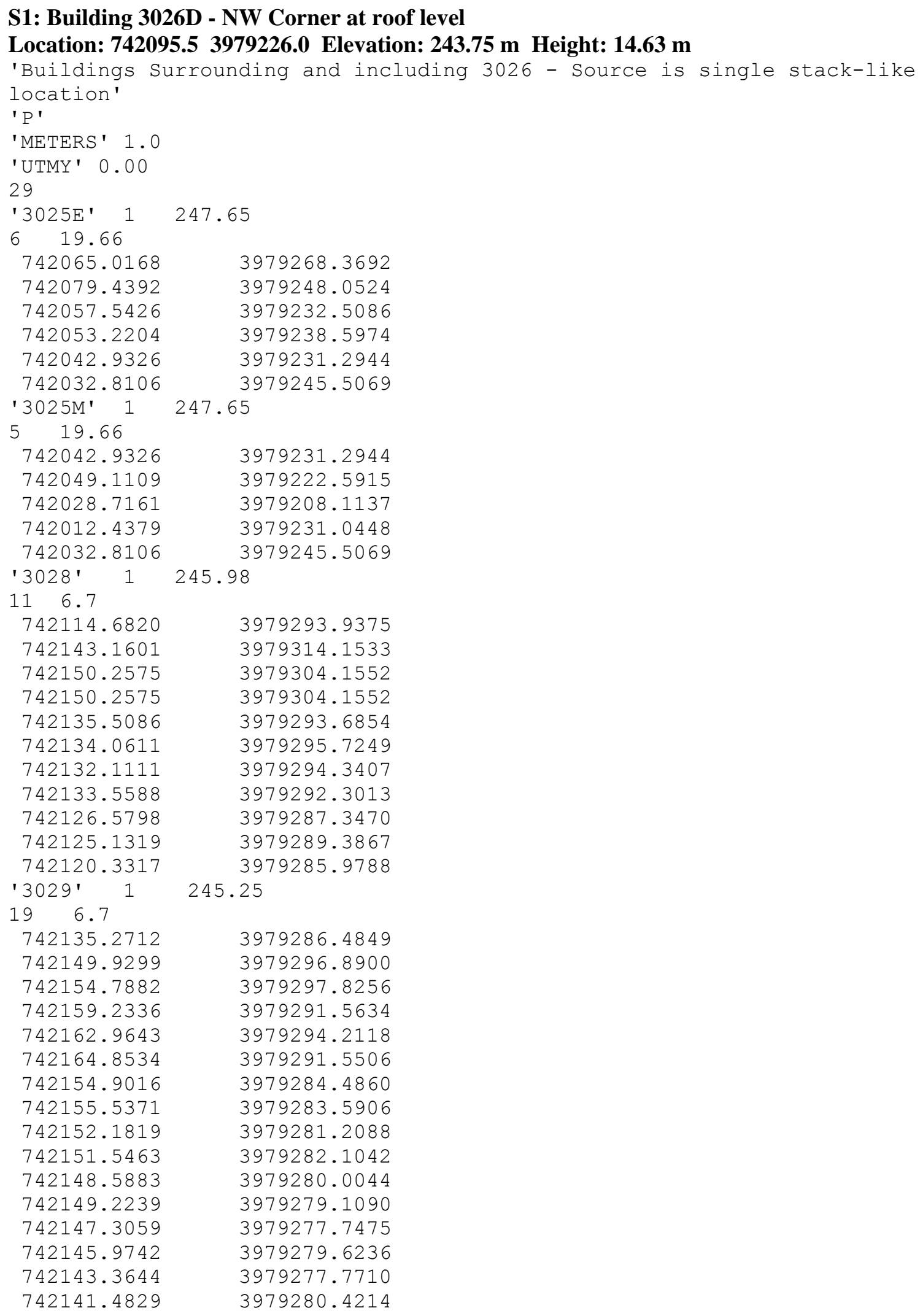




\begin{tabular}{|c|c|}
\hline 742138.0259 & 3979277.9673 \\
\hline 742134.2654 & 3979283.2646 \\
\hline 742136.4545 & 3979284.8186 \\
\hline '3038' 1 & 243.89 \\
\hline 47.0 & \\
\hline 742194.6260 & 3979282.9119 \\
\hline 742203.6478 & 3979270.2029 \\
\hline 742167.3349 & 3979244.4253 \\
\hline 742158.3296 & 3979257.1112 \\
\hline '3039' 1 & 245.36 \\
\hline $8 \quad 76.2$ & \\
\hline 742099.5919 & 3979270.5225 \\
\hline 742103.4267 & 3979269.8718 \\
\hline 742105.7441 & 3979266.6072 \\
\hline 742105.0333 & 979262.8040 \\
\hline 742101.9681 & 3979260.6281 \\
\hline 742098.0156 & 979261.2336 \\
\hline 742095.7690 & 3979264.3984 \\
\hline 742096.4516 & 268.2933 \\
\hline '3092' 1 & 243.91 \\
\hline $12 \quad 6.7$ & \\
\hline 742132.2115 & 3979248.4048 \\
\hline 742137.1727 & 979251.9270 \\
\hline 742138.1791 & 3979250.5093 \\
\hline 742139.0494 & 3979251.1277 \\
\hline 742145.8114 & 3979241.6020 \\
\hline 742147.4280 & 3979242.7496 \\
\hline 742150.7296 & 79238.0986 \\
\hline 742145.7305 & 3979234.5499 \\
\hline 742142.3757 & 3979239.2757 \\
\hline 742139.3911 & 3979237.1570 \\
\hline 742132.6825 & 3979246.6074 \\
\hline 742133.2165 & 3979246.9865 \\
\hline '3105' 1 & 244.23 \\
\hline $4 \quad 6.7$ & \\
\hline 742094.6117 & 3979241.5382 \\
\hline 742097.5601 & 3979237.3848 \\
\hline 742088.6062 & 3979231.0286 \\
\hline 742085.6577 & 3979235.1821 \\
\hline '3125' 1 & 246.64 \\
\hline $4 \quad 3.73$ & \\
\hline 742090.4464 & 3979296.2355 \\
\hline 742097.3583 & 3979301.1420 \\
\hline 742100.4427 & 3979296.7971 \\
\hline 742093.5308 & 3979291.8905 \\
\hline '3150' 1 & 243.41 \\
\hline $8 \quad 8.9$ & \\
\hline 742019.2291 & 3979179.0202 \\
\hline 742028.9976 & 3979165.2593 \\
\hline 742031.4936 & 3979167.0311 \\
\hline 742031.2581 & 3979167.3629 \\
\hline 742053.6213 & 3979183.2379 \\
\hline 742053.8523 & 3979182.9048 \\
\hline 742056.3518 & 3979184.6791 \\
\hline 742046.5879 & 3979198.4415 \\
\hline '3515' 1 & 242.02 \\
\hline $8 \quad 6.7$ & \\
\hline
\end{tabular}




\begin{tabular}{|c|c|}
\hline 742079.6804 & 3979121.6838 \\
\hline 742079.8044 & 3979121.5091 \\
\hline 742081.6732 & 3979122.8357 \\
\hline 742088.0239 & 3979113.8895 \\
\hline 742083.5383 & 3979110.7053 \\
\hline 742079.2751 & 3979116.7109 \\
\hline 742078.3780 & 3979116.0740 \\
\hline 742076.1665 & 3979119.1894 \\
\hline ' $3525^{\prime} \quad 1$ & 242.31 \\
\hline $8 \quad 35.5$ & \\
\hline 742100.1893 & 3979160.9651 \\
\hline 742126.9264 & 3979179.94 \\
\hline 742148.5023 & 3979149.5509 \\
\hline 742136.0786 & 3979140.7316 \\
\hline 742137.7388 & 3979138.3929 \\
\hline 742131.7921 & 3979134.1715 \\
\hline 742130.1319 & 3979136.5102 \\
\hline 742121.7653 & 3979130.5710 \\
\hline ' 3546 ' 1 & 242.28 \\
\hline $4 \quad 7.3$ & \\
\hline 742169.3751 & 3979205.1409 \\
\hline 742194.0726 & 3979222.67 \\
\hline 742200.4284 & 3979213.7195 \\
\hline 742175.7309 & 3979196.1874 \\
\hline ' 3550 ' 1 & 242.45 \\
\hline $16 \quad 6.7$ & \\
\hline 742154.3030 & 3979203.2 \\
\hline 742161.7203 & $979192.7 \varepsilon$ \\
\hline 742154.1829 & 3979187.4322 \\
\hline 742161.3713 & 3979177.30 \\
\hline 742173.1611 & 3979185.6752 \\
\hline 742182.2697 & 3979172.84 \\
\hline 742170.4799 & 3979164.4746 \\
\hline 742177.7717 & 3979154.2027 \\
\hline 742164.9695 & 3979145.1148 \\
\hline 742157.6778 & 3979155.3867 \\
\hline 742153.7717 & 3979152.6139 \\
\hline 742144.6631 & 3979165.4453 \\
\hline 742148.5691 & 3979168.2181 \\
\hline 742141.3808 & 3979178.3443 \\
\hline 742137.4747 & 3979175.5715 \\
\hline 742130.0575 & 3979186.0203 \\
\hline '3026C' 2 & 243.06 \\
\hline 137.3 & \\
\hline 742099.2000 & 3979195.8000 \\
\hline 742077.3463 & 3979180.2911 \\
\hline 742073.9408 & 3979185.0884 \\
\hline 742077.4000 & 3979187.6000 \\
\hline 742071.9181 & 3979195.3526 \\
\hline 742065.6273 & 3979204.2145 \\
\hline 742068.2108 & 3979206.0517 \\
\hline 742067.1998 & 3979207.4738 \\
\hline 742065.7100 & 3979206.4162 \\
\hline 742061.4643 & 3979212.3972 \\
\hline 742068.9139 & 3979217.6855 \\
\hline 742074.2210 & 3979210.2093 \\
\hline 742083.9055 & 3979217.0840 \\
\hline
\end{tabular}




$\begin{array}{ll}742094.9000 & 3979201.8000 \\ 742088.2000 & 3979211.0000 \\ 742069.8000 & 3979198.2000 \\ 742076.6000 & 3979188.7000\end{array}$

' $3026 D^{\prime} 2243.85$

$8 \quad 7.3$

742106.7690

742123.4848

3979236.5788

3979213.0313

742109.5562

3979203.1104

3979195.8000

3979217.0788

3979224.3270

3979224.4473

3979226.6805

742092.8146

1014.63

742106.7690

3979236.5788

3979213.0313

3979203.1104

3979209.0000

3979201.8000

3979211.0000

3979218.2000

3979224.3270

3979224.4473

3979226.6805

742092.8146

' 3034 ' $1 \quad 244.62$

48.5

742201.9503

742209.3654

742202.6501

742195.2350

'3036' 1244.63

$4 \quad 6.1$

742205.6431

742213.4281

742221.6024

742213.8174

' 3037 ' 1

47.4

$742208.4475 \quad 3979292.6858$

$742217.5044 \quad 3979279.9273$

$742236.4816 \quad 3979293.3986$

$742227.4246 \quad 3979306.1572$

' 3047 ' $1 \quad 245.98$

$8 \quad 10.36$

$742144.0075 \quad 3979312.9595$

$\begin{array}{ll}742196.9597 & 3979350.5488\end{array}$

$742204.0573 \quad 3979340.5504$

$\begin{array}{ll}742178.0658 & 3979322.1005\end{array}$

$\begin{array}{ll}742179.8315 & 3979319.6132\end{array}$

$\begin{array}{ll}742163.0755 & 3979307.7297\end{array}$

$742161.3070 \quad 3979310.2140$

$742151.1051 \quad 3979302.9611$

'3130' $1 \quad 244.12$

$6 \quad 6.7$

$742004.1889 \quad 3979229.1763$ 


\begin{tabular}{|c|c|}
\hline 742012.9751 & 3979216.7263 \\
\hline 742001.4710 & 3979208.5733 \\
\hline 741996.8873 & 3979215.0303 \\
\hline 741992.6600 & 3979212.0096 \\
\hline 741988.4131 & 3979217.9923 \\
\hline '3137' 1 & 244.18 \\
\hline 7.0 & \\
\hline 741983.9870 & 3979208.2823 \\
\hline 741984.6546 & 3979207.3418 \\
\hline 741986.8554 & 3979208.9041 \\
\hline 741991.1154 & 3979202.9030 \\
\hline 741988.9146 & 3979201.3407 \\
\hline 741990.7068 & 3979198.8161 \\
\hline 741971.0873 & 3979184.8930 \\
\hline 741969.2147 & 3979187.5309 \\
\hline 741967.1541 & 3979186.0682 \\
\hline 741962.9787 & 3979191.9546 \\
\hline 741965.0235 & 3979193.4351 \\
\hline 741964.3695 & 3979194.3563 \\
\hline ' 3500 ' 2 & 242.47 \\
\hline $4 \quad 6.0$ & \\
\hline 742222.0258 & 3979247.4531 \\
\hline 742252.4295 & 3979269.0359 \\
\hline 742284.6024 & 3979223.7138 \\
\hline 742254.1998 & 3979202.1318 \\
\hline $10 \quad 8.5$ & \\
\hline 742216.4647 & 3979243.8052 \\
\hline 742221.8849 & 3979247.6521 \\
\hline 742254.1998 & 3979202.1318 \\
\hline 742259.9013 & 3979194.0958 \\
\hline 742255.0706 & 3979190.6985 \\
\hline 742263.6568 & 3979178.5971 \\
\hline 742246.1518 & 3979166.1708 \\
\hline 742202.0283 & 3979228.3277 \\
\hline 742218.9333 & 3979240.3281 \\
\hline 742216.4647 & 3979243.8052 \\
\hline$' 3508$ ' 2 & 240.73 \\
\hline $4 \quad 2.74$ & \\
\hline 742176.8988 & 3979093.4792 \\
\hline 742180.4281 & 3979088.5075 \\
\hline 742162.0221 & 3979075.4416 \\
\hline 742158.4928 & 3979080.4133 \\
\hline $10 \quad 6.7$ & \\
\hline 742149.6635 & 3979092.8512 \\
\hline 742180.0072 & 3979114.3913 \\
\hline 742184.6377 & 3979107.8682 \\
\hline 742194.8386 & 3979115.1095 \\
\hline 742198.7710 & 3979109.5699 \\
\hline 742188.5702 & 3979102.3286 \\
\hline 742188.8365 & 3979101.9534 \\
\hline 742176.8988 & 3979093.4792 \\
\hline 742180.4281 & 3979088.5075 \\
\hline 742162.0221 & 3979075.4416 \\
\hline ' 3517 ' 2 & 240.85 \\
\hline $25 \quad 8.23$ & \\
\hline 742125.0732 & 3979072.3 \\
\hline 742136.1942 & 3979056 . \\
\hline
\end{tabular}




\begin{tabular}{|c|c|c|}
\hline 742134.6176 & 3979055.6096 & \\
\hline 742137.9252 & 3979050.9501 & \\
\hline 742132.9786 & 3979047.4386 & \\
\hline 742129.6709 & 3979052.0981 & \\
\hline 742122.2509 & 3979046.8309 & \\
\hline 742125.5586 & 3979042.1714 & \\
\hline 742122.6965 & 3979040.2793 & \\
\hline 742119.4548 & 3979044.8460 & \\
\hline 742105.3736 & 3979034.8502 & \\
\hline 742101.8072 & 3979039.8742 & \\
\hline 742089.0232 & 3979030.7993 & \\
\hline 742085.8473 & 3979035.2732 & \\
\hline 742098.6313 & 3979044.3481 & \\
\hline 742094.2527 & 3979050.5163 & \\
\hline 742088.4407 & 3979058.7037 & \\
\hline 742096.9487 & 3979064.7434 & \\
\hline 742096.2634 & 3979065.7088 & \\
\hline 742103.3569 & 3979070.7443 & \\
\hline 742109.8542 & 3979061.5914 & \\
\hline 742117.4744 & 3979067.0008 & \\
\hline 742114.5645 & 3979071.0999 & \\
\hline 742120.5868 & 3979075.3749 & \\
\hline 742123.4966 & 3979071.2758 & \\
\hline $4 \quad 13.4$ & & \\
\hline 742127.8532 & 3979068.4779 & \\
\hline 742133.4142 & 3979060.6458 & \\
\hline 742102.5936 & 3979038.7574 & \\
\hline 742097.0327 & 3979046.5993 & \\
\hline$' 3542$ ' 1 & 242.34 & \\
\hline $4 \quad 6.7$ & & \\
\hline 742046.3090 & 3979049.2112 & \\
\hline 742050.8133 & 3979052.4086 & \\
\hline 742055.7232 & 3979045.4919 & \\
\hline 742051.2190 & 3979042.2945 & \\
\hline '3587' 1 & 240.42 & \\
\hline $6 \quad 6.7$ & & \\
\hline 742275.6366 & 3979198.2473 & \\
\hline 742293.5940 & 3979210.9948 & \\
\hline 742299.3673 & 3979202.8618 & \\
\hline 742289.5169 & 3979195.8692 & \\
\hline 742293.8069 & 3979189.8259 & \\
\hline 742285.7000 & 3979184.0710 & \\
\hline '3606' 1 & 241.34 & \\
\hline 46.1 & & \\
\hline 742190.8808 & 3979174.8345 & \\
\hline 742215.0759 & 3979192.0099 & \\
\hline 742221.4318 & 3979183.0562 & \\
\hline 742197.2368 & 3979165.8808 & \\
\hline '3618' 1 & 239.75 & \\
\hline $4 \quad 6.7$ & & \\
\hline 742306.0054 & 3979195.3718 & \\
\hline 742312.8418 & 3979185.8995 & \\
\hline 742305.6941 & 3979180.7407 & \\
\hline 742298.8578 & 3979190.2130 & \\
\hline 1 & & \\
\hline 'STACK' 243.75 & 742095.5 & 3979226.0 \\
\hline
\end{tabular}


S2: 3026D - Center line, left side at ground level Location: 742104.0 3979215.0 Elevation: 243.4 m Height: 1 m

File is the same except for changing the STACK information:

$\begin{array}{llll}\text { 'STACK' } 243.4 & 1 & 742104.00 \quad 3979215.00\end{array}$

S3: 3026D - Center line, right side of at roof level of maintenance covering Location: 742111.03979221 .0 Elevation: $243.41 \mathrm{~m}$ Height: $12.0 \mathrm{~m}$

File is the same except for changing the STACK information:

$\begin{array}{llll}\text { 'STACK' } 243.41 & 12.0 & 742111.00 & 3979221.00\end{array}$

S4: Building 3026C - NW side of building at ground level

Location: 742080.00 3979209.00 Elevation: 243.49 m Height: 0 m

File is the same as that for building 3026D except for changing the STACK information (source location and elevation):

$\begin{array}{llll}\text { 'STACK' } 243.49 & 1 & 742080.00 & 3979209.00\end{array}$

\section{S5: Building 3140 - Center at ground level}

Location: 742090.54 3979250.83 Elevation: 244.69 m Height: 0 m

File is the same as pervious except for the addition of building 3140 and changing the STACK information (source location and elevation):

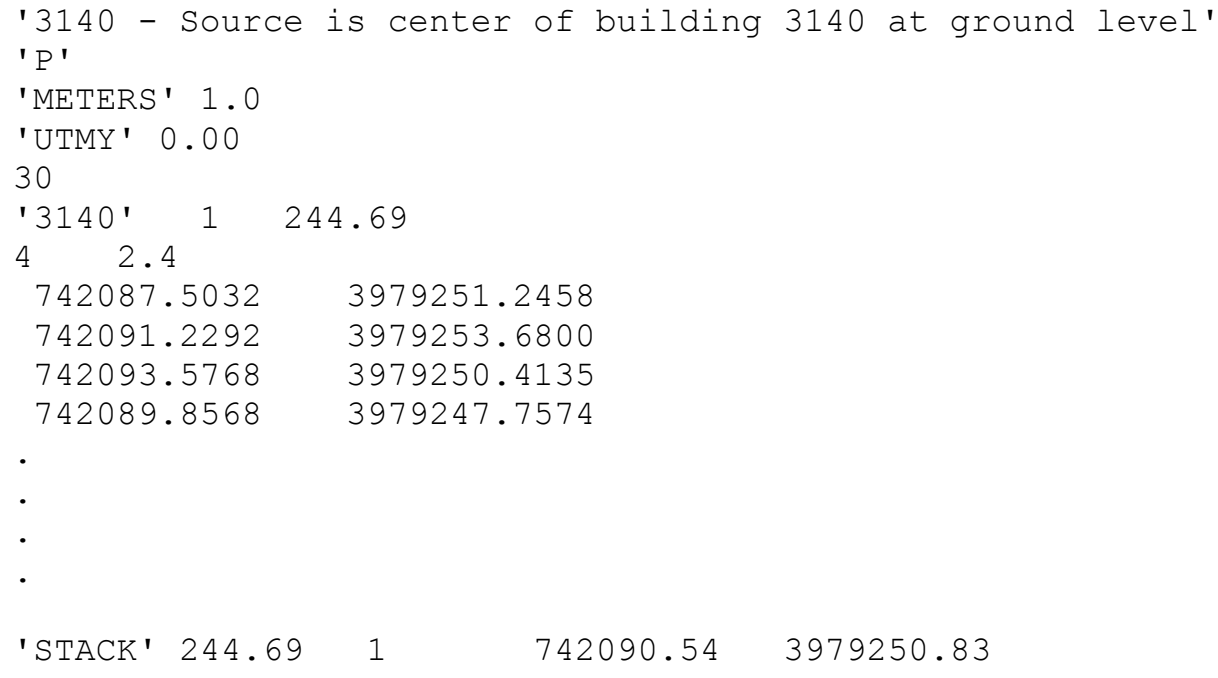


APPENDIX D. AERMAP INPUT FOR COMPUTING ELEVATION OF RECEPTOR LOCATIONS 


\section{APPENDIX D: AERMAP INPUT FOR COMPUTING ELEVATION OF RECEPTOR LOCATIONS}

The AERMAP code is run using the receptor UTM coordinates to obtain the elevations, in this example, of the polar grid points. The output of AERMAP, the elevation values for each receptor location for all polar angles followed by the hill values for each of the receptor rings $(50 \mathrm{~m}, 100 \mathrm{~m}, 200 \mathrm{~m}$, and $500 \mathrm{~m})$, are pasted into the AERMOD input file for this source.

Polar grid elevations are created using this AERMAP input (example is for S5):

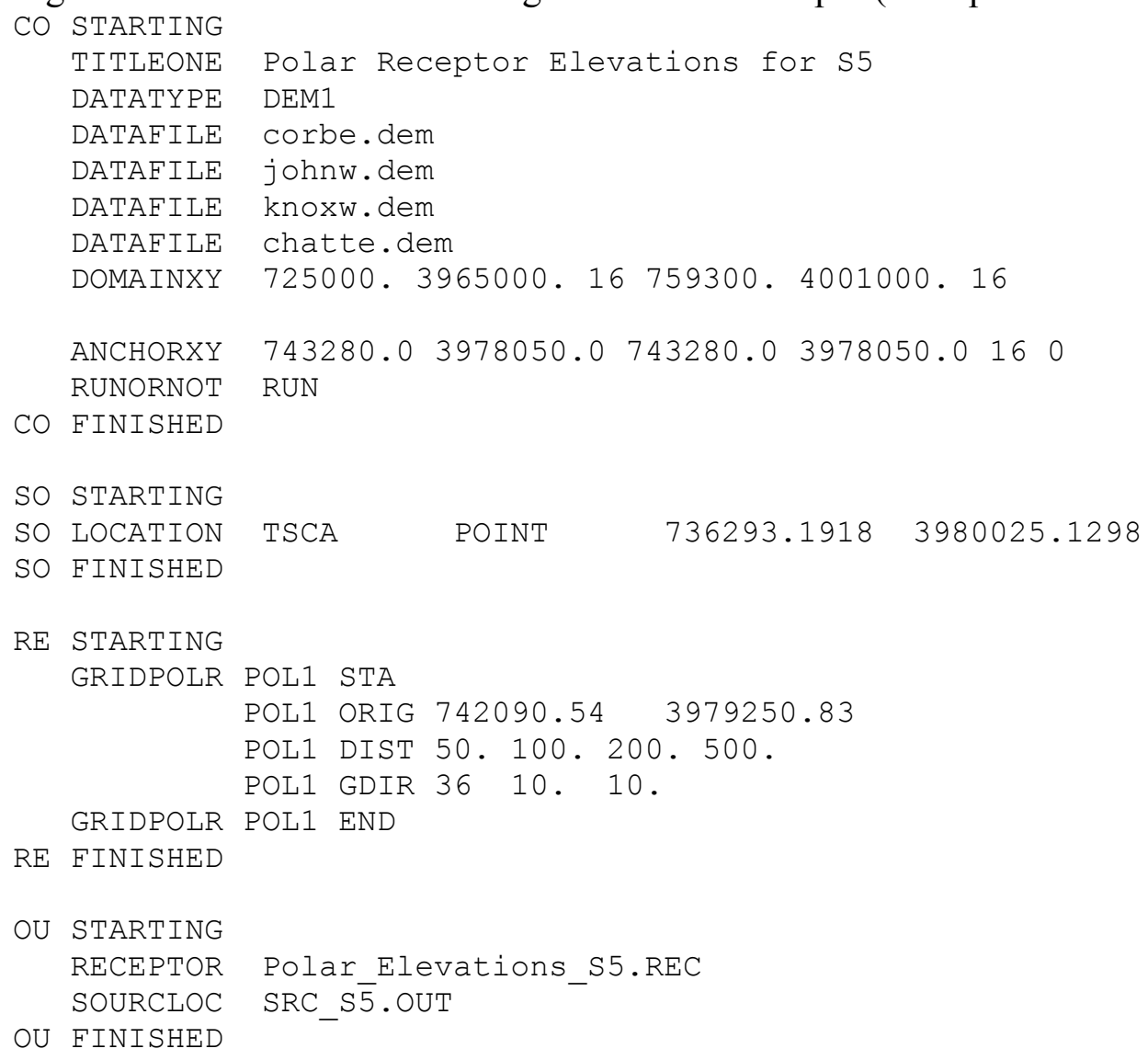


APPENDIX E. SOURCE INVENTORIES AND EFFECTIVE DOSE COEFFICIENTS 


\section{APPENDIX E: SOURCE INVENTORIES AND EFFECTIVE DOSE COEFFICIENTS}

Effective dose coefficients for the radionuclides used in this study are listed in Table E.1. For all radionuclides in the inventory, effective dose coefficients were computed for inhalation intakes, exposure to radiation emitted by the dispersing airborne radionuclides, and exposure to radiation emitted by radionuclides deposited onto the ground surface. The contribution of these pathways to the receptor dose is proportional to the predicted air concentration of the radionuclide at the receptors location. We assume that exposure to deposited activity would be limited to a 4 hour period following the release and that the deposited activity reflects a deposition velocity of $0.01 \mathrm{~m} / \mathrm{s}(1 \mathrm{~cm} / \mathrm{s})$. The relative contribution of each pathway to the receptor dose can be obtained by summing the inhalation coefficients time $1.5 \mathrm{~m}^{3} / \mathrm{h}$ divided by $3660 \mathrm{~s} / \mathrm{h}$ plus the submersion coefficient plus $0.01 \mathrm{~m} / \mathrm{s} \times 4 \mathrm{~h} \times 3600 \mathrm{~s} / \mathrm{h}$ times the ground plane coefficient. The last column of Table E.1 indicates, for each radionuclide, the fraction of the total dose to the receptor due to inhalation of the radionuclide. For these radionuclides and the above assumptions, the inhalation pathway is seen to dominate the total dose. For only one nuclide, Co-57, did inhalation contributed less than $96 \%$. That nuclide only appears in the inventory of building $3026 \mathrm{D}$ and is a minor contributor to the total dose. Thus, in practice, one only needs to consider the inhalation pathway as reflected in Tables E.2-E.4 and thus these tables report $\sum Q_{\mathrm{i}} e_{\mathrm{i}}(\mathrm{Sv})$ for the inventory as needed in Eq. (3) of this report, where $e_{\mathrm{i}}$ is the effective dose coefficient for inhalation.

Table E.1. Dose coefficients for inhalation, submersion and ground plane exposures

\begin{tabular}{lcccr} 
& $\begin{array}{c}--- \text { Effective Dose Coefficients ---- } \\
\text { Inhalation } \\
\text { Sv/Bq }\end{array}$ & $\begin{array}{c}\text { Submersion } \\
\text { Sv-m3/Bq-s }\end{array}$ & $\begin{array}{c}\text { Ground Plane } \\
\text { Sv-m2/Bq-s }\end{array}$ & $\begin{array}{c}\text { fraction } \\
\%\end{array}$ \\
\hline $\mathrm{H}-3$ & $2.6 \mathrm{E}-10$ & 0.0 & 0.0 & 100.00 \\
$\mathrm{C}-14$ & $5.8 \mathrm{E}-09$ & $2.60 \mathrm{E}-18$ & $1.28 \mathrm{E}-20$ & 100.00 \\
$\mathrm{Co}-57$ & $1.0 \mathrm{E}-09$ & $4.98 \mathrm{E}-14$ & $1.09 \mathrm{E}-16$ & 86.42 \\
$\mathrm{Co}-60$ & $3.1 \mathrm{E}-08$ & $1.19 \mathrm{E}-13$ & $2.30 \mathrm{E}-15$ & 96.63 \\
$\mathrm{Sr}-90$ & $1.6 \mathrm{E}-07$ & $8.91 \mathrm{E}-16$ & $1.12 \mathrm{E}-16$ & 99.97 \\
$\mathrm{Cs}-137$ & $3.9 \mathrm{E}-08$ & $2.56 \mathrm{E}-14$ & $5.52 \mathrm{E}-16$ & 99.38 \\
$\mathrm{Eu}-152$ & $4.2 \mathrm{E}-08$ & $5.28 \mathrm{E}-14$ & $1.07 \mathrm{E}-15$ & 98.83 \\
$\mathrm{Eu}-154$ & $5.3 \mathrm{E}-08$ & $5.76 \mathrm{E}-14$ & $1.17 \mathrm{E}-15$ & 98.99 \\
$\mathrm{Am}-241$ & $9.6 \mathrm{E}-05$ & $6.77 \mathrm{E}-16$ & $2.33 \mathrm{E}-17$ & 100.00 \\
$\mathrm{Pu}-239$ & $1.2 \mathrm{E}-04$ & $3.49 \mathrm{E}-18$ & $2.84 \mathrm{E}-19$ & 100.00 \\
$\mathrm{~Np}-237$ & $5.0 \mathrm{E}-05$ & $9.46 \mathrm{E}-15$ & $2.11 \mathrm{E}-16$ & 100.00 \\
$\mathrm{Cm}-244$ & $5.7 \mathrm{E}-05$ & $3.41 \mathrm{E}-18$ & $6.44 \mathrm{E}-19$ & 100.00 \\
\hline
\end{tabular}


Table E.2 Radioactive material inventory summary for Bldg. 3026C

\begin{tabular}{lccc} 
& & \multicolumn{2}{c}{ Dose Coefficients } \\
Nuclide & $\mathrm{Ci}$ & $\mathrm{Bq}$ & $\begin{array}{c}\text { Inhalation } \\
\text { Sv/Bq }\end{array}$ \\
$\mathrm{H}-3$ & $6.10 \mathrm{E}-03$ & $2.26 \mathrm{E}+08$ & $2.60 \mathrm{E}-10$ \\
$\mathrm{C}-14$ & $2.16 \mathrm{E}-02$ & $7.99 \mathrm{E}+08$ & $5.80 \mathrm{E}-09$ \\
$\mathrm{C}-60$ & $1.56 \mathrm{E}-05$ & $5.77 \mathrm{E}+05$ & $3.10 \mathrm{E}-08$ \\
$\mathrm{~S}-90$ & $8.74 \mathrm{E}-03$ & $3.23 \mathrm{E}+08$ & $1.60 \mathrm{E}-07$ \\
$\mathrm{Cs}-137$ & $1.45 \mathrm{E}-02$ & $5.36 \mathrm{E}+08$ & $3.90 \mathrm{E}-08$ \\
$\mathrm{~Np}-237$ & $1.35 \mathrm{E}-04$ & $4.99 \mathrm{E}+06$ & $5.00 \mathrm{E}-05$ \\
\hline \multicolumn{4}{c}{$\sum Q \boldsymbol{e}=3.27 \mathrm{E}+02 \mathrm{SV}$}
\end{tabular}

Table E.3 Radioactive material inventory summary for Bldg. 3026D

\begin{tabular}{lccc} 
& & \multicolumn{3}{c}{ Dose Coefficients } \\
Nuclide & $\mathrm{Ci}$ & $\mathrm{Bq}$ & $\begin{array}{c}\text { Inhalation } \\
\text { Sv/Bq }\end{array}$ \\
\hline $\mathrm{S}-90$ & $9.43 \mathrm{E}+00$ & $3.49 \mathrm{E}+11$ & $1.60 \mathrm{E}-07$ \\
$\mathrm{Pu}-239$ & $3.30 \mathrm{E}-02$ & $1.22 \mathrm{E}+09$ & $1.20 \mathrm{E}-04$ \\
$\mathrm{Am}-241$ & $7.29 \mathrm{E}-04$ & $2.70 \mathrm{E}+07$ & $9.60 \mathrm{E}-05$ \\
$\mathrm{Co}-57$ & $1.47 \mathrm{E}-02$ & $5.44 \mathrm{E}+08$ & $1.00 \mathrm{E}-09$ \\
$\mathrm{Co}-60$ & $6.94 \mathrm{E}-02$ & $2.57 \mathrm{E}+09$ & $3.10 \mathrm{E}-08$ \\
$\mathrm{Cs}-137$ & $3.01 \mathrm{E}+00$ & $1.11 \mathrm{E}+11$ & $3.90 \mathrm{E}-08$ \\
$\mathrm{Eu}-154$ & $3.52 \mathrm{E}-04$ & $1.30 \mathrm{E}+07$ & $5.30 \mathrm{E}-08$ \\
\hline & & $\sum Q \boldsymbol{e}=2.09 \mathrm{E}+05 \mathrm{SV}$
\end{tabular}

Table E.4 Radioactive material inventory summary for Filter House 3140

\begin{tabular}{|c|c|c|c|}
\hline Nuclide & $\begin{array}{c}----- \\
C i\end{array}$ & $\begin{array}{c}\text { ase }----- \\
\mathrm{Bq}\end{array}$ & $\begin{array}{c}\text { Inhalation } \\
\text { Sv/Bq }\end{array}$ \\
\hline $\mathrm{Cs}-137$ & $1.78 E-04$ & $6.59 E+06$ & $3.90 E-08$ \\
\hline Eu-154 & $1.01 E-06$ & $3.74 E+04$ & $5.30 E-08$ \\
\hline $\mathrm{Co}-60$ & $7.12 \mathrm{E}-07$ & $2.63 E+04$ & $3.10 \mathrm{E}-08$ \\
\hline Sr-90 & $3.39 E-06$ & $1.25 E+05$ & $1.60 \mathrm{E}-07$ \\
\hline$E u-152$ & $1.73 E-06$ & $6.40 \mathrm{E}+04$ & $4.20 \mathrm{E}-08$ \\
\hline
\end{tabular}


